\title{
ipen
}

INSTITUTO DE PESQUISAS ENERGÉTICAS E NUCLEARES

Autarquia associada à Universidade de São Paulo

\section{DESENVOLVIMENTO DE MÉTODO PARA SEPARAÇÃO QUÍMICA DE GÁLIO-67 PELA TÉCNICA DE DIFUSÃO TÉRMICA}

\author{
Patricia de Andrade Martins
}

Tese apresentada como parte dos requisitos para obtenção do Grau de Doutor em Ciências na Área de Tecnologia Nuclear - Aplicações

Orientador:

Prof. Dr. João Alberto Osso Júnior 
A Deus, primeiramente, acima de tudo, sobre todas as coisas.

“TUDO É UM EM DEUS" (Mestre Masaharu Taniguchi)

\section{OFEREÇO}

Ao Igor, meu filho, meu amor, minha vida. Agradeço a Deus todos os dias pela sua existência. "Um anjo do céu, que veio pra mim. É o mais bonito, a jóia perfeita". (Anjo do Céu, Música de Natiruts).

Aos meus pais, Cândido e Margarida, pela vida, amor, dedicação e sacrifícios. "Eu tenho tanto pra lhe falar, mas com palavras não sei dizer, como é grande o meu amor por vocês". (Como é Grande o Meu Amor por Você, Música de Roberto Carlos).

Ao Guga. "Ter um irmão é ter para sempre uma infância lembrada com segurança em outro coração".(Tati Bernardi). Ao Francisco. "Amar não é olhar um para o outro, é olhar juntos na mesma direção".(Antoine de Saint-Exupéry). À minha avó Regina (in memoriam) "Para estar junto não é preciso estar perto, e sim dentro".(Leonardo da Vinci).

À Melissa. "Um bebê é a opinião de Deus de que a vida deve continuar". (Carl Sandburg). 


\section{AGRADECIMENTO ESPECIAL}

Ao meu orientador Prof. Dr. João Alberto Osso Júnior a quem, com as palavras abaixo, tento expressar, em palavras, o quanto quero e devo agradecer.

Agradeço por tê-lo em minha vida. Agradeço pela orientação deste trabalho, pela confiança em mim depositada, por acreditar em mim e em minha capacidade, inclusive nos momentos em que nem eu mesma acreditava.

Agradeço pela sua amizade, pelos ensinamentos mais variados, pelo apoio em tantos momentos da minha vida, por seus conselhos, por nossas conversas, por nossas risadas, por nosso besteirol, por suas broncas, pelos "puxões de orelhas", por me tratar diversas vezes como uma filha, quando eu ainda "nem era gente". Já nem me lembro do quanto já aprendi com você.

Agradeço seu sorriso diário, seu otimismo e seu bom humor fácil, sua gargalhada espontânea, sua gentileza gratuita, sua bondade natural. Agradeço sua Luz que ilumina aos que estão ao seu redor.

"Dar o exemplo não é a melhor maneira de influenciar os outros. É a única."

(Albert Schweitzer).

As pessoas entram em nossa vida por acaso, mas não é por acaso que elas permanecem. (Lilian Tonet) 


\section{AGRADECIMENTOS}

Ao fim de quatro anos, com a conclusão deste trabalho, sinto-me muito feliz de agradecer a todos que fizeram parte dele e parte da minha vida em todos estes anos de IPEN.

Foram muitas as pessoas que me ajudaram. As maneiras de auxílio foram das mais diversas: um material emprestado, um preparo de solução, fitas cortadas, um envio de alvo para o cíclotron, uma irradiação, uma monitoração, uma assinatura, uma carona, um almoço, um término de análise, um lembrete de tantas coisas que costumo esquecer, uma sugestão, uma critica, uma conversa, uma gentileza.

"Ninguém consegue realizar nada sem a colaboração de muitos" (Paola Rhoden).

\section{"A receita de vida melhor será sempre melhorar-nos, através da melhora que venhamos a realizar para os outros" (Emmanuel, Chico Xavier).}

Ao Instituto de Pesquisas Energéticas e Nucleares (IPEN) por possibilitar a realização deste trabalho.

Ao Msc. Jair Mengatti, Diretor da Radiofarmácia pela oportunidade concedida e pelo apoio sempre presente.

À Msc. Neuza T. O. Fukumori, Gerente do Controle de Qualidade, minha querida chefe, pelo apoio, oportunidade, paciência, compreensão, doçura e todo o carinho nestes anos.

À Dra. Margareth M. N. Matsuda, pela amizade, apoio, ensinamentos, paciência, e pelo seu tempo.

Aos mais que queridos companheiros e amigos do Controle de Qualidade: Ademar C. Filho, Antônio Carlos Freire, Carlos F. Felgueiras, Claudia Regina Pereira, Edson "Pipa" Vieira Alves, Irene Vicente, José Alcides S. Lima, Laércio da Silva, Natanael Gomes da Silva, Vivian Mendonça, em especial ao Domingos Gomes de Campos pela realização das fotos.

Aos amigos do coração: José Luiz da Silva, Marcelo P. de Souza Ramos, Ideli Morais de Oliveira, Antônio Carlos "Biquinho" Gomes.

Agradeço a presença de todos vocês em minha vida, em meu dia-a-dia. Agradeço à amizade, o apoio, a paciência, os galhos quebrados, os ensinamentos, as diferenças, e o que nos aproxima. Agradeço por tudo. Todos vocês foram e são muito importantes, não só na realização deste trabalho como em todos estes meus anos de IPEN.

Ao Renato Arthur Benvenutti, Ana Lúcia V. P. Lima, Cléo de S. Batista, Msc. Luís Alberto P. Dias e também ao Msc. Marcos O. Damasceno, pelos ensinamentos transmitidos relacionados ao tema deste trabalho, por todas as facilidades oferecidas, 
pela amizade e por toda prontidão em colaborar sempre que necessitei.

Ao Dr. Haroldo Taurian Gasiglia pela colaboração e sugestões fundamentais e oportunas desde o início deste trabalho. Agradeço por acreditar neste trabalho e me ensinar seu valor e sua importância.

Ao Dr. Valdir Sciani, Gerente do Centro de Aceleradores Cíclotron, ao Dr. Hylton Matsuda e aos demais funcionários do CAC pela contribuição, pela gentileza e por todas as facilidades oferecidas com as irradiações necessárias na execução deste trabalho.

Aos funcionários e amigos do Grupo de Moléculas Marcadas: Rosana Herrerias, Adriano A. de Souza, Edmilson Bambalas, Geraldo M. de Azevedo, João A. dos Santos, José A. T. "Pi" Pires, Orlando O. da Silva, em especial ao Wilson A. Bruzinga, a quem eu mais atormentei. A todos vocês, pela gentileza e pela prontidão em me auxiliar sempre que precisei com o vai-e-vem dos alvos do ciclotron.

Aos funcionários e amigos da Divisão de Garantia da Qualidade Fabio Lazzarutti e Renato Brito pela amizade e colaboração sempre presente.

Aos funcionários da Proteção Radiológica Msc. Eduardo Gerullis, Evandro A. de Almeida, Olavo P. da Silva, Jurandyr S. de Carvalho, Christovam R. R. Filho e aos demais funcionários deste grupo por toda colaboração.

A Dra. Fátima M. S. de Carvalho, Dra. Renata C. Nieto, Dra. Deborah I. T. Favaro e ao Dr. Fábio L. N. Marques pela gentileza em participarem da Comissão Julgadora deste trabalho.

Ao Dr. José Martinelli e a Flávia R. de O. Silva pela gentileza e pelo auxílio com as micrografias de MEV.

Aos funcionários e amigos Msc. Marycel R. F. F. de Barboza, Dra. Elaine B. de Araújo, Dra. Maria Tereza Colturato, Fátima das N. Gilli, Neli P. da Silva, Enócles Melo de Oliveira, Geraldo A. Pereira, Benedito Aragão de A. Dias, Roberto T. Yamashita, Rubens F. Millan, Sandra R. F. Alves, Tonisson L. de Azevedo, Wagner Nieto, Wellington C. de Carvalho, Jorge A. da S. Rego, Peterson Lima Squair, Francisca Salete, Ilze C. Puglia, pela amizade e auxílio em diversos momentos e das mais diversas formas.

A Dra. Josiane Zini pela amizade e pelos conhecimentos transmitidos.

A Dra. Bluma L. Faintuch, Dra. Emiko Muramoto e Dra. Nilda P. S. de Pereira minha gratidão pelos ensinamentos de vida, pelos conhecimentos transmitidos, pelo exemplo, pelas oportunidades, pela amizade, pelo carinho, pela contribuição em minha formação profissional e pessoal, pela presença em minha vida.

As amigas Dra. Dulcila M. L. Bernardes, Dra. Vanessa Moraes, Dra. Tatiana Lavinas (in memoriam), Dra. Priscilla B. Pujatti, Dra. Carla R. de B. R. Dias, Dra. Kátia N. Suzuki, Msc. Tânia de P. Brambilla, Msc. Graciela Barrio, Dra. Renata F. Costa, Msc. Renata M. Couto, Dra. Josefina da S. Santos. A todas, pela amizade, pelo estimulo constante, pela parceria, pelo apoio, de tantas formas e em vários momentos.

As amigas Msc. Elisiane de G. Monteiro, Msc. Marcela F. Caetanoso, Msc. Adriana V. F. Massicano, Msc. Erika V. de Almeida, Camila Zanette, Msc. Larissa Carvalho, Msc. Angélica B. Barbezan, Stella Benedetti, Angélica T. Tavares, Sofia Caumo, Rebeca G. 
Moura, Juliana G. Lima e ao amigo Samuel de B. Levindo, pelo apoio e pela ajuda sempre gentil.

Às cavaleiras Fabiana C. Biondo Lário e Andréa Tubor Froenher por fazerem parte da minha vida desde um tempo imemorial, por me oferecerem uma amizade genuína e por não me deixarem esquecer que sonhos valem a pena.

Aos familiares de todas as partes: Andradas, Bueno Brandão, Belo Horizonte, Porto Alegre, São Paulo. 
"As coisas mais importantes são as mais difíceis de expressar. São coisas das quais você se envergonha, pois as palavras as diminuem - as palavras reduzem as coisas que pareciam ilimitáveis quando estavam dentro de você à mera dimensão normal quando são reveladas. Mas é mais que isso, não? As coisas mais importantes estão muito perto de onde seu segredo está enterrado, como pontos de referência para um tesouro que seus inimigos adorariam roubar. E você pode fazer revelações que Ihe são muito difíceis e as pessoas o olharem de maneira esquisita, sem entender nada do que você disse nem por que eram tão importantes que você quase chorou quando estava falando. Isso é pior, eu acho. Quando o segredo fica trancado lá dentro não por falta de um narrador, mas de alguém que compreenda." 


\title{
DESENVOLVIMENTO DE MÉTODO PARA SEPARAÇÃO QUÍMICA DE GÁLIO-67 PELA TÉCNICA DE DIFUSÃO TÉRMICA
}

\author{
Patricia de Andrade Martins
}

\section{RESUMO}

Radioisótopos de gálio são estudados e avaliados para aplicações médicas desde 1949. Nos últimos 50 anos ${ }^{67} \mathrm{Ga}$ tem sido amplamente utilizado no diagnóstico de diversas patologias, incluindo lesões inflamatórias crônicas e agudas, bacterianas ou estéreis e diversos tipos de tumores. No Brasil 30\% das clinicas que prestam serviços de Medicina Nuclear utilizam o Citrato de ${ }^{67}$ Ga com uma demanda de distribuição no IPEN-CNEN/SP de $37 \mathrm{GBq}(1 \mathrm{Ci})$ por semana. $0{ }^{67} \mathrm{Ga}$ apresenta meia-vida física de 3,26 dias (78 horas) e decai $100 \%$ por captura eletrônica para $0{ }^{67} \mathrm{Zn}$ estável. Seu decaimento inclui a emissão de raios $\gamma$ com energias de 93,3 keV (37\%), 184,6 keV (20,4\%), 300,2 keV (16,6\%) e 888 keV (26\%). No IPEN o ${ }^{67} \mathrm{Ga}$ era produzido a partir da reação ${ }^{68} \mathrm{Zn}(p, 2 n)^{67} \mathrm{Ga}$. Após a irradiação, o alvo era totalmente dissolvido em $\mathrm{HCl}$ concentrado e a solução percolada em resina catiônica DOWEX 50W-X8, 200-400 mesh, condicionada em $\mathrm{HCl} 10$ mol L-1. Zinco, níquel e cobre eram eluídos em $\mathrm{HCl} 10 \mathrm{~mol} \mathrm{~L}^{-1}$ e o ${ }^{67} \mathrm{Ga}$ em HCl 3,5 $\mathrm{mol} \mathrm{L}^{-1}$. O produto final era obtido na forma de citrato de ${ }^{67} \mathrm{Ga}$. Este trabalho apresenta um método inédito, rápido, direto e eficiente de separação química e obtenção de ${ }^{67} \mathrm{GaCl}_{3}$ a partir da difusão térmica (aquecimento do alvo) aliada à extração em ácido acético concentrado. $\mathrm{A}$ purificação foi realizada por cromatografia de troca iônica. Realizou-se a eletrodeposição do zinco natural em placas de cobre niquelado como substrato e os depósitos de zinco obtidos foram aderentes ao substrato, levemente brilhantes e uniformes. Os alvos foram irradiados com prótons de $26 \mathrm{MeV}$ e corrente integrada de $10 \mu \mathrm{A}$.h. Após a irradiação, os alvos foram aquecidos a $300{ }^{\circ} \mathrm{C}$ por 2 horas e colocados em contato com ácido acético concentrado por 1 hora. O rendimento médio de extração de ${ }^{67} \mathrm{Ga}$ obtido foi de

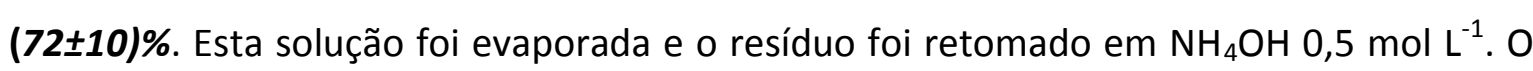


${ }^{67} \mathrm{Ga}$ foi purificado em resina catiônica Dowex 50WX8 em meio de $\mathrm{NH}_{4} \mathrm{OH}$. A recuperação obtida foi de (98 \pm 2$) \%$, de ${ }^{67} \mathrm{Ga}$. O eluido foi evaporado e retomado em $\mathrm{HCl} 0,1 \mathrm{~mol} \mathrm{~L}^{-1}$. A pureza química foi verificada por ICP-OES encontrando-se $(2 \pm 1) \mu g \mathrm{~mL}^{-1}$ de zinco. As concentrações de ferro, cobre e níquel foram inferiores ao limite de detecção do método e aos limites de utilização de ${ }^{67} \mathrm{Ga}$. A pureza radionuclídica foi verificada por espectroscopia- $\gamma$ utilizando um detector de germânio Hiper-Puro encontrando-se valor superior a $\left(\mathbf{9 9 , 9 \% )}\right.$. Este método inédito permite a obtenção de ${ }^{67} \mathrm{Ga}$ com alta pureza química, radioquímica e radionuclídica em condições de processamento menos agressivas e corrosivas que o método comumente utilizado. 


\title{
DEVELOPMENT OF METHOD TO CHEMICAL SEPARATION OF GALLIUM-67 BY THERMAL DIFFUSION TECHNIQUE
}

\section{Patricia de Andrade Martins}

\begin{abstract}
Radioisotopes of gallium have been studied and evaluated for medical applications since 1949. Over the past 50 years ${ }^{67} \mathrm{Ga}$ has been widely used in the diagnosis of various diseases, including acute and chronic inflammatory lesions, bacterial or sterile and several types of tumors. In Brazil 30\% of clinics that provide services for Nuclear Medicine use ${ }^{67} \mathrm{Ga}$ citrate and the demand for ${ }^{67} \mathrm{Ga}$ at IPEN-CNEN/SP is $37 \mathrm{GBq}(1 \mathrm{Ci}) /$ week. The ${ }^{67} \mathrm{Ga}$ presents physical half-life of 3.26 days ( 78 hours) and decays $100 \%$ by electron capture to stable ${ }^{67} \mathrm{Zn}$. Its decay includes the emission of $\gamma$ rays with energies of $93.3 \mathrm{keV}(37 \%)$, $184.6 \mathrm{keV}(20.4 \%), 300.2 \mathrm{keV}(16.6 \%)$ and $888 \mathrm{keV}(26 \%)$. In the past ${ }^{67} \mathrm{Ga}$ was produced by the reaction ${ }^{68} \mathrm{Zn}(\mathrm{p}, 2 \mathrm{n}){ }^{67} \mathrm{Ga}$ at IPEN-CNEN/SP. After irradiation, the target was dissolved in concentrated $\mathrm{HCl}$ and the solution percolated through a cationic resin DOWEX 50W-X8, 200-400 mesh, conditioned with $10 \mathrm{~mol} \mathrm{~L}^{-1} \mathrm{HCl}$. Zinc, nickel and copper were eluted in $10 \mathrm{~mol} \mathrm{~L}^{-1} \mathrm{HCl}$ and ${ }^{67} \mathrm{Ga} 3.5 \mathrm{~mol} \mathrm{~L}^{-1} \mathrm{HCl}$. The final product was obtained as ${ }^{67} \mathrm{Ga}$ citrate. This work presents a new, fast, direct and efficient method for the chemical separation of ${ }^{67} \mathrm{Ga}$ by thermal diffusion (heating of the target) combined with concentrated acetic acid extraction. Purification was performed by ion exchange chromatography. Natural zinc electrodeposition was performed on nickel/copper plates as substrate and the zinc deposits were adherent to the substrate, slightly shiny and uniform. The targets were irradiated with $26 \mathrm{MeV}$ protons and integrated current of 10 $\mu$ A.h. After irradiation, the targets were heated at $300{ }^{\circ} \mathrm{C}$ for 2 hours and placed in contact with concentrated acetic acid for 1 hour. The average yield of extraction of ${ }^{67} \mathrm{Ga}$ was $(72 \pm \mathbf{1 0}) \%$. This solution was evaporated and the residue was taken up in $0.5 \mathrm{~mol} \mathrm{~L}^{-1}$ $\mathrm{NH}_{4} \mathrm{OH}$. The ${ }^{67} \mathrm{Ga}$ was purified on cationic resin Dowex $50 \mathrm{WX} 8$ in $\mathrm{NH}_{4} \mathrm{OH}$ medium. The
\end{abstract}


${ }^{67} \mathrm{Ga}$ recovery was $(98 \pm 2) \%$. This solution was evaporated and taken up in $0.1 \mathrm{~mol} \mathrm{~L}^{-1}$ $\mathrm{HCl}$. The chemical purity was evaluated by ICP-OES that resulted in $(2 \pm 1) \mu g \mathrm{~mL}^{-1}$ of zinc. The concentration of iron, copper and nickel was lower than the detection limits and also than the utilization limits for ${ }^{67} \mathrm{Ga}$. The radionuclidic purity was greater than (99.9\%). This method showed to be suitable to obtain high purity ${ }^{67} \mathrm{Ga}$ in less aggressive chemical conditions than before. 


\section{SUMÁRIO}

Página

1 INTRODUÇÃO

1.1 Um pouco de história 1

1.2 Produção de radionuclídeos 2

1.2.1 Produção de radionuclídeos em cíclotron 4

1.2.2 Preparo de alvos para irradiação 6

1.2.3 Preparo de alvos por eletrodeposição 7

$\begin{array}{lll}1.3 & 10\end{array}$

1.4 Produção de radioisótopos no Brasil 13

1.5 Boas práticas de fabricação de radiofármacos 15

1.6 Produção do ${ }^{67}$ Ga no IPEN/CNEN-SP 16

2 OBJETIVOS 19

3 REVISÃO DA LITERATURA

3.1 Utilização do ${ }^{67} \mathrm{Ga}$ em Medicina nuclear 20

3.2 Histórico, descoberta e ocorrência do gálio 26

3.3 Propriedades químicas e físico-químicas do gálio 26

3.4 Propriedades físicas e nucleares do gálio 29

3.5 Métodos de separação do ${ }^{67} \mathrm{Ga}$ dos materiais alvos 34

3.5.1 Métodos utilizando a extração por solventes 34

3.5.2 Métodos utilizando a cromatografia 37

3.5.2.1 Processos de separação por cromatografia de extração 37

3.5.2.2 Processos de separação por cromatografia de adsorção 38

3.5.2.3 Processos de separação por cromatografia de troca iônica 39

3.5.3 Métodos utilizando a difusão térmica 44

$4 \quad$ MATERIAIS E MÉTODOS

4.2 Métodos 46

4.2.1 Fluxograma dos experimentos 46

4.2.2 Preparo de alvos por eletrodeposição 47

4.2.3 Estudos de difusão térmica com placas não irradiadas 50

4.2.4 Análise química das soluções obtidas nos ensaios com placas não 52 irradiadas

4.2.5 Irradiações no Cyclone-30 53

4.2.6 Ensaios de difusão térmica com placas irradiadas 53

4.2.7 Separação química em resina aniônica Dowex 1X8 54

4.2.7.1 Comportamento de $\mathrm{Cu}, \mathrm{Ni}$ e $\mathrm{Zn} \quad 56$

4.2.7.2 Comportamento do ${ }^{67} \mathrm{Ga}$ 
4.2.7.3 Separação química de ${ }^{67} \mathrm{Ga} / \mathrm{Zn}$ nas placas irradiadas $\quad 57$

4.2.8 Separação química de ${ }^{67} \mathrm{Ga} / \mathrm{Zn}$ em resina catiônica Dowex 50WX8 57

4.2.9 Análise química das soluções obtidas com a purificação em resina de 59 troca iônica

4.2.10 Determinação da pureza radioquímica do ${ }^{67} \mathrm{Ga}$

4.2.11 Determinação da pureza radionuclídica do ${ }^{67} \mathrm{Ga} \quad 60$

4.2.12 Preparação de citrato de ${ }^{67} \mathrm{Ga} \quad 61$

4.2.13 Análise estatística 62

5 RESULTADOS E DISCUSSÕES

5.1 Preparo de alvos por eletrodeposição 63

5.2 Resultados da difusão térmica em placas de cobre, placas de cobre 69 niquelada e placas contendo depósito de zinco não irradiadas

5.3 Análise química das soluções obtidas nos ensaios com placas não 74 irradiadas

5.4 Irradiações no Cyclone $30 \quad 77$

5.5 Resultados da Difusão Térmica em Placas Irradiadas 80

5.6 Comportamento de $\mathrm{Cu}, \mathrm{Ni}, \mathrm{Zn}$ e ${ }^{67} \mathrm{Ga}$ em Resina Aniônica Dowex $1 \times 8 \quad 81$

5.7 Separação Química de ${ }^{67} \mathrm{Ga} / \mathrm{Zn}$ em Resina Aniônica Dowex 1 X8 83

5.8 Separação Química de ${ }^{67} \mathrm{Ga} / \mathrm{Zn}$ em Resina Catiônica Dowex 50WX8 85

5.9 Pureza Radioquímica do ${ }^{67} \mathrm{Ga} \quad 87$

5.10 Pureza Radionuclídica do ${ }^{67} \mathrm{Ga} \quad 87$

5.11 Pureza Radioquímica do Citrato de ${ }^{67} \mathrm{Ga}$

$5.12 \quad$ Fluxograma do Método Proposto 89

6 CONCLUSÕES 90

$7 \quad$ REFERÊNCIAS BIBLIOGRÁFICAS 92 


\section{LISTA DE TABELAS}

Tabela

Página

TABELA 1 Vias de produção de radionuclídeos 4

TABELA 2 Características físicas dos radionuclídeos utilizados em diagnóstico 12

TABELA 3 Características físicas dos radionuclídeos utilizados em terapia 12

TABELA 4 Especificações do ${ }^{67}$ Ga importado da empresa NORDION 17

TABELA 5 Gálio-67: aplicações em medicina nuclear 25

TABELA 6 Propriedades físico-químicas do gálio 28

TABELA 7 Radioisótopos de gálio 30

TABELA 8 Emissão de elétrons produzidos pelo decaimento do ${ }^{67} \mathrm{Ga}$

TABELA 9 Emissão de fótons produzidos pelo decaimento do ${ }^{67} \mathrm{Ga}{ }^{(73)} 32$

TABELA 10 Reações nucleares para produção de ${ }^{67} \mathrm{Ga}$

TABELA 11 Recursos utilizados na execução do trabalho 45

TABELA 12 Características das placas utilizadas e condições de eletrodeposição 48

TABELA 13 Radionuclídeos provenientes da irradiação de alvos de ${ }^{\text {nat }} \mathrm{Zn}$ em 61 substrato de cobre niquelado

TABELA 14 Resultados da eletrodeposição de Zn em placas para difusão 64

TABELA 15 Resultados da eletrodeposição de Zn em placas para irradiação 65

TABELA 16 Análise da espessura da camada de Zn eletrodepositado em placas 67 para irradiação

TABELA 17 Diferença de massa nas placas de cobre $(\mathrm{Cu})(\mathrm{n}=3)$

TABELA 18 Diferença de massa nas placas de cobre niquelada $(\mathrm{Ni} / \mathrm{Cu})(\mathrm{n}=3)$

TABELA 19 Diferença de massa nas placas contendo depósito de zinco 71 $(\mathrm{Zn} / \mathrm{Ni} / \mathrm{Cu})(\mathrm{n}=3)$

TABELA 20 Massa de alvos de ${ }^{67}$ Ga após irradiação 77

TABELA 21 Resultados para produção de ${ }^{67} \mathrm{Ga} \quad 79$

TABELA 22 Resultados obtidos na extração do ${ }^{67} \mathrm{Ga}$ em ácido acético 80

TABELA 23 Resultados obtidos na purificação do ${ }^{67}$ Ga eluído 83 


\section{LISTA DE FIGURAS}

Figura

Página

FIGURA 1 Esquema do cíclotron 5

FIGURA 2 Estrutura química do citrato de ${ }^{67} \mathrm{Ga}$

FIGURA 3 Planos coronal (A), sagital (B) e axial (C) de imagem SPECT/CT (Skylight, 24 Philips) obtidas após 48 horas de administração de $150 \mathrm{MBq}$ de citrato de ${ }^{67} \mathrm{Ga}$. A região indicada mostra infecção da prótese da válvula aórtica pósoperatória

FIGURA 4 SPECT/CT de citrato de ${ }^{67} \mathrm{Ga}$, planos coronal (A), sagital (B) e axial (C), obtidas após o tratamento com antibióticos, indicando o fim da infecção

FIGURA 5 Esquema de decaimento do ${ }^{67} \mathrm{Ga}$

FIGURA 6 Função de excitação para a reação ${ }^{67} \mathrm{Zn}(p, n){ }^{67} \mathrm{Ga}$

FIGURA 7 Função de excitação para a reação ${ }^{68} \mathrm{Zn}(p, 2 n){ }^{67} \mathrm{Ga}$

FIGURA 8 Fluxograma dos experimentos

FIGURA 9 Cuba de eletrodeposição e seus componentes: (1) ânodo de platina; (2) cuba de acrílico; (3) eletrólito; (4) placa de cobre niquelado; (5) cátodo de ferro

FIGURA 10 Cuba de eletrodeposição de ${ }^{\text {nat }} \mathrm{Zn}$ para preparo de Alvos para irradiação

FIGURA 11 Aparato de vidro para extração do ${ }^{67} \mathrm{Ga}$ em HAc

FIGURA 12 Estação de irradiação para alvos sólidos do Cyclone-30

FIGURA 13 Curva de adsorção para o níquel e o cobre em ácido acético

FIGURA 14 Curva de adsorção para o zinco e o gálio em ácido acético

FIGURA 15 Placa Contendo Zn eletrodepositado para estudos de difusão $(12 \times 3 \mathrm{~cm})$

FIGURA 16 Alvo de Zn eletrodepositado para irradiação $(7 \times 2,7 \mathrm{~cm})$

FIGURA 17 Micrografia de Zn com ampliação de 25 vezes

FIGURA 18 Micrografia de Zn com ampliação de 1000 vezes

FIGURA 19 Diferença de massa a $25^{\circ} \mathrm{C}$ 
FIGURA 21 Diferença de massa a $200{ }^{\circ} \mathrm{C}$

FIGURA 22 Concentração de $\mathrm{Cu}$, Ni e Zn a $25^{\circ} \mathrm{C}$, em placas de cobre, placa de cobre niquelada e placa contendo depósito de zinco

FIGURA 23 Concentração de $\mathrm{Cu}, \mathrm{Ni}$ e $\mathrm{Zn}$ a $100^{\circ} \mathrm{C}$, em placas de cobre, placa de cobre 75 niquelada e placa contendo depósito de zinco

FIGURA 24 Concentração de $\mathrm{Cu}$, Ni e $\mathrm{Zn}$ a $200{ }^{\circ} \mathrm{C}$, em placas de cobre, placa de cobre 76 niquelada e placa contendo depósito de zinco

FIGURA 25 Separação química de Zn, Ni e Cu em resina aniônica Dowex 1 X8 $(n=3)$

FIGURA 26 Separação química de ${ }^{67} \mathrm{Ga}$ em resina aniônica Dowex 1X8 (n=3)

FIGURA 27 Curva de eluição do ${ }^{67} \mathrm{Ga}^{+3}$ em resina aniônica Dowex $1 X 8(n=5)$ 85

FIGURA 28 Curva de eluição do ${ }^{67} \mathrm{Ga}$ em resina catiônica Dowex $50 \mathrm{WX} 8(n=5)$ 86

FIGURA 29 Cromatograma do citrato de ${ }^{67} \mathrm{Ga}(\mathrm{n}=5)$ 88

FIGURA 30 Obtenção de ${ }^{67}$ Ga por difusão térmica e extração em ácido acético 89 


\section{1}

\section{INTRODUÇão}

\subsection{Um pouco de história (1)}

A história da medicina nuclear começou com as descobertas da radioatividade natural por Henri Becquerel, em 1896, e de elementos radioativos naturais por Marie e Pierre Curie, em 1898. Entretanto, foi o "princípio do traçador", proposto pelo químico húngaro George de Hevesy, em 1913, que realmente forneceu o fundamento biológico para a especialidade. Ele confirmou o princípio através de experiências com nitrato de chumbo-201, mostrando sua absorção e distribuição em plantas.

Em 1927, Herrmann L. Blumgart e Soma Weiss realizaram a primeira medida da velocidade sanguínea, mediante a injeção de uma solução de radônio em um braço e a verificação da sua chegada no outro braço, utilizando uma câmara de Wilson.

Em 1932, a invenção e a construção do cíclotron, por Ernest O. Lawrence e M. Stanley Livingstone, possibilitaram a produção de radionuclídeos artificiais, através do bombardeamento de núcleos-alvos por prótons acelerados.

Entretanto, a produção de quantidades suficientes de radionuclídeos para uso médico só se iniciou com o advento dos reatores nucleares, desenvolvidos durante a Segunda Guerra Mundial. O reator de Oak Ridge, nos Estados Unidos, iniciou sua produção em escala comercial em 1946, e o de Harwell, no Reino Unido, em 1947.

Inicialmente, existiam poucos radionuclídeos adequados para as aplicações médicas, e grande parte dos estudos clínicos enfocava a avaliação da glândula tireóide e suas disfunções, com o uso do ${ }^{131}$ I (lodo-131) na forma de iodeto de sódio. O principal detector usado era o contador Geiger-Müller, que indicava e media a presença do radioisótopo, sem, contudo, distinguir a energia da radiação gama detectada e sem 
produzir imagens da distribuição do composto.

Em 1951, Benedict Cassen desenvolveu o mapeador linear e deu início à era de diagnóstico por imagens utilizando radionuclídeos.

Em 1958, Hal Anger desenvolveu a câmara de cintilação cujas informações adquiridas eram transformadas em imagens e exibidas por um tubo de raios catódicos, de modo que podiam ser registradas em filmes ou chapas fotográficas. As modernas câmaras usadas hoje são derivadas da câmara Anger.

O grande poder diagnóstico da Medicina Nuclear se firmou quando Paul Harper e sua equipe introduziram o radionuclídeo ${ }^{99 \mathrm{~m}} \mathrm{Tc}$ (Tecnécio-99m) como marcador. Esse nuclídeo emite um fóton único com energia de $140 \mathrm{keV}$, bastante adequado para a câmara de Anger, e possui meia-vida física de 6 horas, possibilitando estudos em intervalos de tempo razoáveis. É produzido pelo sistema gerador ${ }^{99} \mathrm{Mo} /{ }^{99 \mathrm{~m}} \mathrm{Tc}$ (Molibdênio-99 / Tecnécio-99m) e consegue se ligar a inúmeras moléculas orgânicas, tornando possíveis estudos de diversos órgãos e sistemas do corpo humano.

Nas décadas de 1960 e 1970, com novos avanços em computação foi possível adquirir, armazenar, processar e programar métodos de reconstrução de imagens obtidas a partir da realização de Tomografias por Emissão de Fótons Únicos (single photon emission computed tomography, SPECT) e da realização de Tomografias por Emissão de Pósitrons (positron emission tomography, PET).

Associada ao desenvolvimento farmacológico, a pesquisa para melhorar a instrumentação, com o uso de detectores mais eficientes e de eletrônica mais rápida, tem impulsionado a modalidade SPECT e PET em suas aplicações.

Estima-se que exista mais de 100 procedimentos diferentes em Medicina Nuclear para fins diagnósticos que utilizam radiofármacos específicos, que cobrem um número considerável de estudos sobre a fisiologia dos sistemas orgânicos do corpo.

\subsection{Produção de radionuclídeos (2)}

Os radionuclídeos usados em Medicina Nuclear para diagnóstico e terapia são produzidos artificialmente em reatores, aceleradores de partículas ou podem, ainda, ser acessíveis através de geradores de radioisótopos. 
Capítulo $1 \mid 3$

Introdução

Os radionuclídeos que decaem por emissão de partículas $\beta^{-}$são geralmente produzidos em reator, por fissão do ${ }^{235} U$ (Urânio-235) ou por reações de captura de nêutrons $(n, \gamma$ ou $n, p)$ numa amostra alvo.

Os radionuclídeos que decaem por captura eletrônica ou emissão de partículas $\beta^{+}$, em geral são produzidos em cíclotrons. Nestas reações, partículas de elevada energia interagem com núcleos estáveis de alvos apropriados, originando produtos deficientes em prótons. Neste processo, as partículas que interagem com as amostras alvo podem ser prótons, deutêrons, partículas $\alpha$ ou ${ }^{3} \mathrm{He}$ (Hélio-3).

Os geradores de radionuclídeos permitem obter um radionuclídeo de tempo de meia-vida física $\left(t_{1 / 2}\right)$ curto a partir de um radionuclídeo de tempo de meia-vida física longo. As propriedades químicas dos dois radionuclídeos têm que ser distintas para que sejam facilmente separados. Os geradores podem ser constituídos por uma coluna de alumina, ou por uma resina de troca iônica, na qual se fixa o radionuclídeo "pai" de $t_{1 / 2}$ longo. Por decaimento deste último, forma-se o radionuclídeo "filho", que é separado por eluição, em eluente adequado. O eluído pode ser utilizado diretamente em aplicações clínicas, constituindo, neste caso, a substância radiofarmacêutica, ou pode servir para preparar radiofármacos mais complexos. O eluído deve ser obtido na forma estéril e isenta de pirogênios. Um gerador ideal deverá ter uma proteção de chumbo para minimizar a exposição à radiação do experimentador, deverá ser simples, rápido de utilizar e originar eluídos isentos do radionuclídeo "pai", do material que constitui a coluna, assim como isento de outros possíveis radionuclídeos contaminantes.

Na TAB. 1 apresentam-se alguns dos radionuclídeos mais utilizados em Medicina Nuclear e suas vias de produção. 
TABELA 1 - Vias de produção de radionuclídeos ${ }^{(2)}$

\begin{tabular}{|c|c|c|}
\hline Fonte & Radionuclídeo & Reação Nuclear \\
\hline \multirow[t]{6}{*}{ REATOR } & ${ }^{131}$ I (lodo-131) & ${ }^{235} U(n, f){ }^{131} I$ \\
\hline & & ${ }^{130} \mathrm{Te}(\mathrm{n}, \gamma){ }^{131} \mathrm{Te} \stackrel{\beta-}{\rightarrow}{ }^{131} \mathrm{I}$ \\
\hline & ${ }^{177}$ Lu (Lutécio-177) & ${ }^{176} \mathrm{Lu}(\mathrm{n}, \gamma){ }^{177} \mathrm{Lu}$ \\
\hline & ${ }^{153}$ Sm (Samário-153) & ${ }^{152} \mathrm{Sm}(\mathrm{n}, \gamma){ }^{153} \mathrm{Sm}$ \\
\hline & ${ }^{99}$ Mo (Molibdênio-99) & ${ }^{235} \mathrm{U}(\mathrm{n}, \mathrm{f}){ }^{99} \mathrm{Mo}$ \\
\hline & & ${ }^{98} \mathrm{Mo}(\mathrm{n}, \gamma){ }^{99} \mathrm{Mo}$ \\
\hline \multirow[t]{5}{*}{ ACELERADOR } & ${ }^{123}$ I (lodo-123) & ${ }^{124} \mathrm{Xe}(\mathrm{p}, 2 \mathrm{n}){ }^{123} \mathrm{Cs} \rightarrow{ }^{123} \mathrm{Xe} \rightarrow{ }^{123} \mathrm{I}$ \\
\hline & ${ }^{67}$ Ga (Gálio-67) & ${ }^{68} \mathrm{Zn}(p, 2 n){ }^{67} \mathrm{Ga}$ \\
\hline & ${ }^{201}$ TI (Tálio-201) & ${ }^{203} \mathrm{Tl}(p, 3 n){ }^{201} \mathrm{~Pb} \rightarrow{ }^{201} \mathrm{Tl}$ \\
\hline & ${ }^{111}$ In (Índio-111) & ${ }^{112} \mathrm{Cd}(p, 2 n)^{111} \operatorname{In}$ \\
\hline & ${ }^{18}$ F (Flúor-18) & ${ }^{18} \mathrm{O}(\mathrm{p}, \mathrm{n}){ }^{18} \mathrm{~F}$ \\
\hline \multirow{3}{*}{ GERADOR } & ${ }^{99 m}$ Tc (Tecnécio-99m) & ${ }^{99} \mathrm{Mo} \stackrel{\beta-}{\rightarrow}{ }^{99 \mathrm{~m}} \mathrm{Tc}$ \\
\hline & ${ }^{68} \mathrm{Ga}$ (Gálio-68) & ${ }^{68} \mathrm{Ge} \stackrel{\mathrm{CE}}{\rightarrow}{ }^{68} \mathrm{Ga}$ \\
\hline & ${ }^{90} \mathrm{Y}$ (Ítrio-90) & ${ }^{235} U(n, f){ }^{90} S r \stackrel{\beta-}{\rightarrow}{ }^{90} Y$ \\
\hline
\end{tabular}

CE - captura eletrônica; $f$ - fissão; $n$ - nêutron; $p$ - próton.

\subsubsection{Produção de radionuclídeos em cíclotron (2)}

O cíclotron é o tipo mais comum de acelerador para produção de radioisótopos e tem como base o eletromagnetismo. Quando uma partícula carregada é inserida em um campo magnético uniforme, em ambiente de vácuo, esta partícula se moverá em círculos e com frequência de movimento determinada pela força do campo magnético, pela sua massa e carga, independentemente de sua velocidade e energia. A FIG. 1 apresenta de modo esquemático um cíclotron.

No cíclotron, as partículas a serem aceleradas são ionizadas por uma fonte de íons (S) que se encontra entre dois eletrodos na forma de "dês" (A e B) e um campo magnético. A aceleração é feita por alternância de voltagem (V) e a partícula é acelerada toda vez que passa pelo espaço entre os dois eletrodos, movimentando-se em forma de espiral. No final de seu trajeto, a partícula é defletida (D) e direcionada para atingir o alvo. 


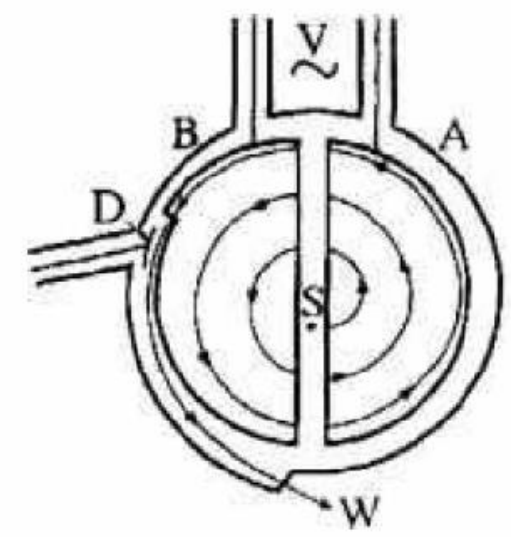

FIGURA 1 - Esquema do cíclotron ${ }^{(2)}$

O processo de produção de radioisótopos em cíclotrons pode ser dividido em: preparo do alvo; irradiação do alvo, tratamento físico e físico-químico do alvo após irradiação, para separação do radioisótopo produzido e controle de qualidade do radioisótopo produzido. Em cada uma das etapas é importante considerar o rendimento de produção, a pureza do produto final e os aspectos econômicos e de segurança. Uma prática comum é o uso de alvos enriquecidos no isótopo estável, o que encarece o processo, tornando necessária a recuperação dos alvos.

Um conceito importante na produção de radioisótopos é a interpretação da interação de partículas com o alvo, a seção de choque, $\sigma$, que expressa a probabilidade de uma determinada reação nuclear ocorrer. Quanto maior a seção de choque, maior a probabilidade de interação da partícula com o núcleo e de ocorrer a reação nuclear para produção do radioisótopo. A seção de choque é normalmente expressa em barn, onde 1 barn equivale a $10^{-24} \mathrm{~cm}^{2}$.

Uma curva representando a seção de choque para uma reação nuclear em função da energia das partículas incidentes é chamada de curva ou função excitação. Como várias reações nucleares podem ocorrer, a curva de excitação permite calcular os rendimentos de reação para um intervalo de energia e auxilia na escolha da energia apropriada para a produção do radioisótopo desejado. 


\subsubsection{Preparo de alvos para irradiação}

Um dos aspectos importantes a se considerar na produção de radioisótopos é o desenvolvimento de sistemas adequados para as irradiações ${ }^{(3)}$.

Os alvos usados para irradiação em cíclotron podem ser classificados em três grupos: alvos sólidos; alvos líquidos e alvos gasosos. Os alvos gasosos são vantajosos para a produção de radioisótopos de meia-vida física curta, como ${ }^{11} \mathrm{C}$ (Carbono-11) e ${ }^{15} \mathrm{O}$ (Oxigênio-15). Os alvos líquidos devem apresentar alto ponto de ebulição e serem estáveis em altas temperaturas ${ }^{(3)}$.

Embora os alvos gasosos tenham preferência em algumas aplicações, a maioria dos alvos empregados para produção de radioisótopos em cíclotrons é sólida, podendo ser na forma de folhas metálicas ou então na forma de óxidos, sais, ligas, preparados por eletrodeposição, laminação de metais, soldagem em suporte, fusão em suporte metálico e compressão de pós para produção de pastilhas. Os suportes normalmente utilizados são de alumínio, cobre e platina ${ }^{(3)}$.

No preparo de alvos sólidos, devem-se escolher metais com boas propriedades térmicas, alto ponto de fusão e alta condutividade térmica, devido ao calor gerado durante o bombardeamento do alvo por partículas carregadas. É importante também existir um sistema adequado de resfriamento nos aceleradores ${ }^{(3)}$.

Por esses motivos, o alvo sólido é preferencialmente irradiado em posição inclinada em relação ao feixe, para haver uma melhor dissipação do calor gerado ${ }^{(3)}$.

Em virtude do alcance das partículas no alvo ser baixo, de apenas algumas centenas de mícrons, um alvo sólido fino pode representar uma espessura de "alvo grosso". Diz-se que um alvo é grosso quando o número de núcleos presentes é suficiente para diminuir a energia das partículas do feixe incidente, abaixo dos valores da energia limiar da reação ${ }^{(3)}$.

O rendimento de uma reação nuclear aumenta com a energia das partículas incidentes. No entanto, para certos radioisótopos é preferível não se exceder a energia das partículas para uma melhora de rendimento, de forma a se evitar a produção de impurezas radionuclídicas indesejáveis, que são geradas em altas energias ${ }^{(3)}$.

Uma maneira de se evitar reações nucleares indesejadas e para que haja um maior rendimento na produção é a utilização de alvos enriquecidos isotopicamente.

Após a irradiação, os alvos são dissolvidos em ácidos fortes concentrados, como o 
ácido clorídrico ou ácido nítrico, que são corrosivos e agressivos aos componentes da cela de processamento. O radioisótopo de interesse é então separado e purificado por troca iônica ou extração por solventes ${ }^{(3)}$.

Vários requisitos devem ser observados no desenvolvimento de um alvo para irradiação ${ }^{(4)}$ :

1) Composição de alta pureza química;

2) Facilidade de preparação;

3) Resistência química e mecânica;

4) Espessura uniforme;

5) Capacidade do material em resistir a altas correntes e em realizar uma eficiente transferência de calor durante a irradiação;

6) Conhecimento dos dados nucleares para obtenção dos melhores rendimentos de produção;

7) Facilidade de separação química dos produtos radioativos obtidos;

8) Facilidade de recuperação do material alvo quando necessário;

9) Alta atividade específica do produto obtido;

10) Obtenção de altas atividades do radionuclídeo de interesse;

11) Preço do alvo.

\subsubsection{Preparo de alvos por eletrodeposição}

Há na literatura vários métodos descritos para a preparação de alvos sólidos, sendo a eletrodeposição um método muito utilizado.

O termo eletrodeposição ou deposição eletrolítica refere-se ao processo de produção de depósitos de um metal a partir de uma reação eletroquímica. Mediante a transferência de carga através de uma interface entre um eletrodo e um eletrólito ocorrem reações químicas resultando em um material sólido depositado na superfície de substratos ${ }^{(5)}$.

Reações onde ocorrem transferência de carga elétrica são chamadas de reações de óxido-redução. Uma célula eletroquímica é um dispositivo que utiliza reações de óxido-redução para conversão de energia química em elétrica. Uma célula eletroquímica consiste em dois condutores chamados eletrodos. O cátodo é o eletrodo no qual ocorre a 
redução (com ganho de elétrons) e o ânodo é o eletrodo no qual ocorre a oxidação (com perda de elétrons) ${ }^{(6)}$.

Existem dois tipos de células eletroquímicas: as células galvânicas e as células eletrolíticas. As células galvânicas ou voltaicas armazenam energia elétrica. As baterias são geralmente feitas de várias dessas células conectadas em série para produzir voltagens mais elevadas que aquelas produzidas por uma única célula. Nessas células, as reações que ocorrem nos eletrodos tendem a prosseguir espontaneamente e produzem um fluxo de elétrons do ânodo para o cátodo através de um condutor externo ${ }^{(6)}$.

Uma célula eletrolítica, em contraste com uma célula voltaica, requer uma fonte externa de energia elétrica para sua operação. As cargas podem se movimentar no sentido de corrente catódica, estimulando a redução das espécies, ou correntes anódicas, envolvendo a oxidação das espécies ${ }^{(6)}$.

Na eletrodeposição, a incorporação de um átomo na rede cristalina de um substrato a partir dos íons em solução pode ser desmembrada em uma sequência de etapas que explicam como se forma o depósito neste processo. A eletrodeposição pode ser descrita por uma série de etapas, citadas a seguir, em forma consecutiva de acontecimento ${ }^{(5)}$.

1 - Difusão dos íons da solução para perto da superfície do eletrodo;

2 - Transferência de elétrons do eletrodo para os íons em solução;

3 - Absorção e perda da solvatação dos átomos na superfície do eletrodo constituindo "adátomos";

4 - Difusão do "adátomo" ao longo da superfície do eletrodo (substrato);

5 - Incorporação dos "adátomos" e crescimento de uma camada na superfície do substrato.

Momentos antes de ocorrer o processo de formação dos filmes finos, os íons metálicos que chegam à superfície do substrato são íons envolvidos por uma camada de moléculas de água, denominada camada de solvatação, e quando envolvidos por outros íons, denomina-se camada de complexação. As camadas de solvatação são mais fracamente ligadas que as camadas de complexação. A eletrodeposição implica na perda dessa camada circundante e a captura de um ou vários elétrons do substrato ${ }^{(5)}$.

O processo inicia-se quando estes íons solvatados chegam até a superfície e 
recebem elétrons desta, originando a formação de adátomos caracterizados pelo estado intermediário entre o estado iônico da solução e o estado metálico no depósito. A difusão de adátomos pela superfície forma um aglomerado ou núcleos de crescimento que serão úteis para a consequente formação da camada sólida ${ }^{(5)}$.

O controle de alguns parâmetros - densidade de corrente, tensão aplicada, composição do banho, temperatura e tempo de processo - durante a eletrodeposição é fundamental para obtenção de filmes com as características desejadas.

Estes parâmetros influem no depósito, modificando, por exemplo, a morfologia superficial, o tamanho do grão, a aderência e a textura ${ }^{(5)}$.

Os processos em que ocorrem transferências de elétrons através da interface eletrodo/eletrólito, mediado por reação de óxido-redução são governados pelas leis de Faraday e são ditos faradaicos ${ }^{(7)}$.

As Leis de Faraday estabelecem que as quantidades de substâncias liberadas ou acumuladas nos eletrodos de uma célula são proporcionais aos seus equivalentes químicos,

$$
m=\frac{M Q}{n F}
$$

onde $\boldsymbol{m}$ é a massa (em gramas) da substância de massa molar $\boldsymbol{M}, \boldsymbol{n}$ é o número de elétrons envolvidos na reação redox, $\boldsymbol{F}$ é a constante de Faraday (96.500 C) e $\boldsymbol{Q}$ é a quantidade de carga que flui pela célula quando uma corrente $\boldsymbol{i}$ (em Ampère) é mantida por um tempo $\boldsymbol{t}$ (em segundos) ${ }^{(7)}$ :

$$
Q=i . t
$$

Ao se realizar um processo de deposição, espera-se que toda a corrente aplicada seja utilizada para a eletrodeposição do material de interesse. Se uma fração desta corrente for utilizada para algum processo que ocorra em paralelo, ela é considerada desperdiçada. De uma maneira geral isto ocorre, principalmente devido à redução paralela do hidrogênio ${ }^{(7)}$. 
A Eficiência de Corrente, ou Eficiência Catódica é definida como a porcentagem total da corrente que foi utilizada na deposição catódica do metal ${ }^{(7)}$ :

$$
\%=\frac{\underline{\mathrm{Q}}_{\text {processo }}}{\mathrm{Q}_{\text {teórico }}} \times 100=\frac{\underline{\mathrm{m}}_{\text {depositado }}}{\mathrm{m}_{\text {teórico }}} \times 100
$$

Na preparação de alvos sólidos por eletrodeposição, a Agência Internacional de Energia Atômica (AIEA) ${ }^{(8)}$ estabelece alguns pré-requisitos que demonstrem uma preparação bem sucedida de um alvo sólido. Estes pré-requisitos estão listados abaixo:

1 - A camada deve ser homogênea sobre toda a superfície, com desvio-padrão na espessura média em $\pm 5 \%$;

2 - A camada deve aderir fortemente ao substrato;

3 - A camada não deve ser esponjosa;

4 - A camada deve ser isenta de qualquer aditivo orgânico ou íons tóxicos (agentes complexantes, surfactantes, cianetos);

5 - O processo deve ser reprodutível, no mínimo, em 10 lotes;

6 - Tratamentos pós-eletrodeposição devem ser excluídos.

\subsection{Medicina nuclear}

Uma importante aplicação dos radioisótopos é sua contribuição para a Medicina Nuclear.

A medicina nuclear é uma especialidade médica que utiliza os radiofármacos para fins de diagnóstico e terapia de diversas doenças. Os radiofármacos são compostos, sem ação farmacológica, que têm na sua composição um radionuclídeo ${ }^{(1,9)}$.

A riqueza da capacidade diagnóstica em medicina nuclear reside na diversidade dos radiofármacos disponíveis que retratam a fisiologia ou a fisiopatologia do sistema em estudo. Radiofármacos tem a propriedade de não perturbar a função, ao contrario de outros tipos de drogas diagnósticas, incluindo os meios de contrastes iodados, que causam efeitos quando administrados por via intravascular.

A maioria dos radiofármacos é uma combinação de um componente radioativo que permite a detecção externa ligado a uma molécula biologicamente ativa responsável 
pela biodistribuição.

A ação da maioria dos radiofármacos é derivada de dois componentes: um componente não radioativo (ligante) e um componente radioativo (radionuclídeo) ${ }^{(10)}$.

Os mecanismos que promovem a ligação do radiofármaco ao sítio alvo podem ser diversos, envolvendo desde uma simples perfusão sanguínea do composto pelos órgãos de interesse, até a ligação a receptores celulares específicos ou participação em uma via metabólica ou processo bioquímico ${ }^{(10)}$.

A escolha de um radionuclídeo para o desenvolvimento de um radiofármaco para aplicação em diagnóstico ou terapia em Medicina Nuclear depende das suas características físicas: o tipo de emissão nuclear, o tempo de meia-vida física ( $t_{1 / 2}$ ) e a energia das partículas e/ou radiação eletromagnética emitida ${ }^{(2)}$.

Certas características são desejáveis em um radiofármaco. Do ponto de vista do marcador radioativo, temos o fóton gama com energia e quantidade adequada para detecção externa. A energia deve estar entre 100 e 300 keV para uma ótima eficiência de detecção. Raios $\gamma$ com energia inferior a $100 \mathrm{keV}$ são absorvidos pelos tecidos e não são detectados exteriormente. Por outro lado, quando a sua energia é superior a $300 \mathrm{keV}$ a eficiência dos detectores atuais é menor, resultando em imagens de baixa qualidade. A meia-vida efetiva deve ser longa o bastante para a aplicação desejada, e os marcadores ideais não devem emitir radiações de partículas ( $\alpha$ ou $\beta^{-}$). A atividade especifica deve ser alta $^{(2,11,12)}$.

Do ponto de vista do fármaco, as características ideais incluem biodistribuição adequada para atingir o objetivo, ausência de toxicidade ou efeitos secundários. Quando administrado intravenosamente, deve ser estéril e livre de pirogênios. Os radiofármacos não devem sofrer dissociação in vitro ou in vivo, devem estar facilmente disponíveis, ser fáceis de marcar e de custo razoável ${ }^{(2,11,12)}$.

Na TAB. 2 são apresentadas as características físicas de alguns dos radionuclídeos utilizados em radiodiagnóstico ${ }^{(2)}$. 
TABELA 2 - Características físicas dos radionuclídeos utilizados em diagnóstico ${ }^{(2)}$

\begin{tabular}{cccccc}
\hline Radionuclídeo & \multicolumn{1}{c}{$\mathbf{t}_{\mathbf{1 / 2}}$} & $\begin{array}{c}\text { Modo de } \\
\text { Decaimento }\end{array}$ & $\begin{array}{c}\text { Energia Raios } \gamma \\
(\mathbf{k e V})\end{array}$ & $\begin{array}{c}\text { Abundância da } \\
\text { Emissão (\%) }\end{array}$ \\
\hline & ${ }^{\mathbf{9 9 m}} \mathbf{T c}$ & 6 horas & $\mathrm{TI}$ & 140 & 89 \\
& ${ }^{131} \mathbf{I}$ & 8 dias & $\beta^{-}$ & 364 & 81 \\
SPECT & ${ }^{123} \mathbf{I}$ & 13 horas & $\mathrm{CE}$ & 159 & 83 \\
& ${ }^{\mathbf{6 7}} \mathbf{G a}$ & 78 horas & $\mathrm{CE}$ & $93,184,300,394$ & $31,20,17,5$ \\
& ${ }^{111} \mathrm{In}$ & 67 horas & $\mathrm{CE}$ & 171,245 & 90,94 \\
\hline & ${ }^{18} \mathbf{F}$ & 110 minutos & $\beta^{+}$ & 511 & 96,9 \\
\hline
\end{tabular}

TI - transição isomérica; CE - captura eletrônica.

A radioterapia pode ser dividida em: terapia com feixe externo ou Teleterapia; terapia com fontes radioativas seladas ou Braquiterapia e terapia com fontes não-seladas que são os Radiofármacos Injetáveis ou Endoterapia ${ }^{(12)}$.

$\mathrm{Na}$ endoterapia, os radionuclídeos que emitem partículas ionizantes (partículas $\alpha$, $\beta^{-}$, elétrons Auger) são indicados para tratamento de tumores. O tipo de partícula a se utilizar depende do tamanho do tumor, da distribuição intratumoral e farmacocinética do radiofármaco.

$\mathrm{Na}$ TAB. 3 são apresentados os principais radionuclídeos com potencial terapêutico.

TABELA 3 - características físicas dos radionuclídeos utilizados em terapia ${ }^{(2)}$

\begin{tabular}{cccccc}
\hline Radionuclídeo & $\begin{array}{c}\mathbf{t}_{1 / 2} \\
\text { (dias) }\end{array}$ & $\begin{array}{c}\text { Modo de } \\
\text { Decaimento }\end{array}$ & $\begin{array}{c}\text { Energia Máxima } \\
\boldsymbol{\beta}^{-}(\mathrm{MeV})\end{array}$ & $\begin{array}{c}\text { Energia Raios } \\
\gamma(\mathrm{MeV})\end{array}$ & $\begin{array}{c}\text { Alcance } \\
\text { Tecidual (mm) }\end{array}$ \\
\hline${ }^{131} \mathrm{I}$ & 8 & $\beta^{-}$ & 0,81 & $0,364(81 \%)$ & 2,4 \\
\hline${ }^{177} \mathrm{Lu}$ & 6,7 & $\beta^{-}$ & 0,50 & $0,113(6,4 \%)$ & - \\
\hline${ }^{153} \mathrm{Sm}$ & 1,9 & $\beta^{-}$ & 0,80 & $0,103(29 \%)$ & 3,0 \\
\hline${ }^{90} \mathrm{Y}$ & 2,7 & $\beta^{-}$ & 2,27 & - & 12,0 \\
\hline
\end{tabular}


A escolha da técnica a ser utilizada no diagnóstico está relacionada ao tipo de emissão do radionuclídeo durante seu decaimento radioativo, podendo a tomografia ser transversal ou longitudinal.

A tomografia longitudinal, ou SPECT, utiliza radiofármacos, preferencialmente constituídos por radioisótopos emissores de fótons simples, raios $\mathrm{X}$ e raios $\gamma$, com energia entre 80-300 keV e com $t_{1 / 2}$ relativamente curto (de horas a poucos dias). Exemplos de radioisótopos utilizados para diagnóstico por SPECT são mostrados na TAB. 2.

As imagens de SPECT são obtidas utilizando-se gama câmaras, associadas a computadores que fazem a aquisição e o tratamento de dados, bem como a um sistema que permite visualizar e registrar as imagens.

Esta técnica produz uma imagem tomográfica, que mostra a distribuição da radiação no corpo do paciente, à medida que o detector vai rodando até $180^{\circ}$ ou $360^{\circ}$ à sua volta. É possível a obtenção de imagens nos diversos planos anatômicos.

A tomografia transversal, ou PET, utiliza radionuclídeos emissores de pósitrons (partículas $\beta^{+}$). Exemplos de radioisótopos utilizados para diagnóstico por PET são mostrados na TAB. 2.

Os pósitrons reagem instantaneamente com elétrons, emitindo dois fótons $\gamma$ com energia de $511 \mathrm{keV}$ cada um, na mesma direção, mas com sentidos opostos, que são recolhidos externamente num detector circular, originando imagens tridimensionais. $A$ detecção simultânea dos fótons que têm sentidos opostos evita a presença de um colimador para limitar o campo de deteç̧ão. O sistema PET usa detectores múltiplos distribuídos em círculo, cada um ligado ao que se encontra na posição oposta.

A imagem cintilográfica obtida permite conhecer a distribuição do radiofármaco no organismo e quantificar a sua fixação em vários órgãos ou tecidos, permitindo o diagnóstico clínico.

\subsection{Produção de radioisótopos no Brasil (13)}

O Instituto de Pesquisas Energéticas e Nucleares (IPEN-CNEN/SP), por meio do seu antigo Departamento de Processamento de Material Radioativo (TP), atual Diretoria de Radiofarmácia (DIRF), foi a Instituição pioneira na produção de radioisótopos e radiofármacos no Brasil.

O IPEN-CNEN/SP é uma autarquia estadual, vinculada à Secretaria de Ciência, 
Tecnologia e Desenvolvimento Econômico do Governo do Estado de São Paulo, gerido técnica e administrativamente pela Comissão Nacional de Energia Nuclear (CNEN) do Ministério da Ciência e Tecnologia e Inovação. O IPEN-CNEN/SP está instalado no campus da Cidade Universitária em São Paulo e é ligado à Universidade de São Paulo por seu programa de pós-graduação.

A produção experimental de radioisótopos foi iniciada em 1959 com o ${ }^{131}$ I. Usado para diagnóstico e terapia de doenças da tireóide, o ${ }^{131}$ I foi fundamental para a viabilização e consolidação da Medicina Nuclear no país.

No final de 1980, o IPEN-CNEN/SP iniciou um programa de desenvolvimento e trabalhos experimentais com ${ }^{99}$ Mo importado do Canadá e em 1981, iniciou o atendimento aos hospitais e clínicas do país com geradores de ${ }^{99} \mathrm{Mo} /{ }^{99 \mathrm{~m}} \mathrm{Tc}$, preparados com tecnologia nacional, atendendo a uma demanda inicial de 10 geradores por semana. Esta demanda vem crescendo anualmente, chegando atualmente à distribuição de 360 geradores semanais.

Outros radiofármacos foram desenvolvidos, produzidos e distribuídos pelo IPENCNEN/SP, como o cloreto de ${ }^{201} \mathrm{TI}$ (estudo da viabilidade cardíaca), o citrato de ${ }^{67} \mathrm{Ga}$ (diagnóstico de tumores específicos, focos de inflamação e infecção), ${ }^{131 / 131}$ I-MIBG(terapia e diagnóstico de feocromocitomas e neuroblastomas), ${ }^{153}$ Sm-EDTMP (paliativo das dores provenientes de metástases óssea).

Em 1999 foi iniciada a produção e distribuição de ${ }^{18}$ F-FDG para estudo da viabilidade miocárdica e localização de tumores. $\mathrm{O}{ }^{18} \mathrm{~F}$ foi o primeiro radioisótopo para uso na técnica de PET produzido no País.

A partir de 1995, o IPEN-CNEN/SP iniciou um programa de nacionalização, com objetivo de passar a produzir parte dos radioisótopos importados. Esse programa se consolidou com o aumento da potência do Reator IEA-R1, possibilitando a produção local de ${ }^{131} \mathrm{I}$ e ${ }^{153} \mathrm{Sm}$ e com a instalação do cíclotron de $30 \mathrm{MeV}$, responsável pela produção nacional de ${ }^{201} \mathrm{TI},{ }^{67} \mathrm{Ga},{ }^{123} \mathrm{I}$ e ${ }^{18} \mathrm{~F}$.

Em 2005 o IPEN-CNEN/SP produziu 100\% da necessidade anual do mercado nacional de ${ }^{201} \mathrm{TI},{ }^{67} \mathrm{Ga}$ e cerca de $60 \%$ de ${ }^{131} \mathrm{I}$.

O programa de nacionalização, associado ao desenvolvimento constante de novos produtos, tem propiciado ao IPEN-CNEN/SP produzir e distribuir para todo o território nacional, diversos produtos radioativos para diagnóstico e tratamentos, entre eles, 
radioisótopos primários, moléculas marcadas e reagentes liofilizados para pronta marcação com ${ }^{99 m} \mathrm{Tc}$.

A Diretoria de Radiofarmácia do IPEN-CNEN/SP conquistou em 1999 a certificação ISO-9001-2000 para produção e distribuição de radiofármacos por meio de um programa de qualidade.

A Diretoria de Radiofarmácia tem por missão aperfeiçoar suas instalações, equipamentos, recursos humanos e atualizar as tecnologias envolvidas, para atender ao crescimento da Medicina Nuclear no país.

\subsection{Boas práticas de fabricação de radiofármacos $(10,14,15)$}

Todo produto a ser administrado em humanos deve reunir requisitos de qualidade, segurança e eficácia.

Boas Práticas de Fabricação (BPF) é um sistema designado para garantir que os fármacos sejam consistentemente produzidos e controlados de acordo com padrões de qualidade, visando eliminar riscos envolvidos na produção. O cumprimento das BPF está direcionado para minimizar os riscos presentes na produção farmacêutica, que não podem ser detectados com a análise do produto final: contaminação cruzada, contaminação com material particulado ou alteração ou mistura de produtos.

As BPF no Brasil são publicadas na Resolução RDC 210 de 04 de agosto de 2003, da Agência Nacional de Vigilância Sanitária (ANVISA) do Ministério da Saúde.

A produção de radiofármacos além de cumprir os requisitos exigidos na RDC 210/2003, deve estar de acordo com a resolução sobre Boas Práticas de Fabricação de Radiofármacos (Resolução RDC 63/2009, ANVISA).

Instalações especiais são necessárias para manipulação de elementos radioativos de modo a prevenir a contaminação do meio ambiente por materiais radioativos liberados durante a manipulação e processamento e para proteção do operador. O processamento de materiais radioativos requer um sistema fechado, blindado, dotado de exaustão e ventilação controlada, denominado "hot cell" (célula quente) ou cela de processamento.

Laboratórios para manipulação de materiais radioativos devem ser especificamente planejados, levando em consideração aspectos de proteção radiológica de limpeza e esterilidade. A ventilação da instalação produtiva e a blindagem da cela 
devem atingir requerimentos para prevenir a contaminação de produtos e a exposição do trabalhador à radiação.

Áreas com pressão positiva são requeridas para processamento de produtos estéreis. Em contrapartida, elementos radioativos são geralmente manipulados em ambientes sob pressão negativa. De acordo com as recomendações da Organização Mundial da Saúde (OMS), o processamento de radiofármacos poderá ser realizado em ambiente com pressão negativa, rodeado por ambiente de pressão positiva, cuja qualidade requerida do ar seja atingida.

As celas construídas para produção de radiofármacos devem atingir os requisitos estabelecidos para um isolador de pressão negativa. As paredes da cela devem ser lisas, impermeáveis, não quebradiças e com cantos arredondados. Aço inox com a superfície polida e o acrílico são recomendados como material de construção.

A pureza do ar das celas deve atingir as recomendações aplicadas para salas limpas de acordo com a regulamentação das BPF.

Deve ser evitada a instalação de componentes de difícil limpeza e a utilização de reagentes que degradem a cela.

Visto isto, é recomendável que o método de produção de um radioisótopo/radiofármaco contribua para o atendimento das regulamentações de BPF utilizando-se de reagentes não corrosivos aos componentes da cela de processamento e que seja passível de automação para facilitar a produção, permitindo assim a classificação do ambiente da cela de produção.

\subsection{Produção do ${ }^{67}$ Ga no IPEN/CNEN-SP}

O Centro de Aceleradores Cíclotron (CAC) iniciou suas atividades na década de 70, com o nome de Divisão de Danos de Radiação ${ }^{(16)}$.

Com a instalação do cíclotron CV-28 (The Cyclotron Corporation - USA), foram realizados os primeiros experimentos para produção dos radioisótopos ${ }^{67} \mathrm{Ga},{ }^{123} \mathrm{I},{ }^{201} \mathrm{Tl} \mathrm{e}$ ${ }^{111} \ln { }^{(16)}$.

O ${ }^{67}$ Ga veio a ser produzido rotineiramente a partir de 1987 , através da irradiação de ${ }^{68} \mathrm{Zn}$ (Zinco-68) enriquecido, pela reação ${ }^{68} \mathrm{Zn}(\mathrm{p}, 2 \mathrm{n}){ }^{67} \mathrm{Ga}{ }^{(16)}$.

Os limites operacionais exigidos durante a irradiação para a produção do ${ }^{67} \mathrm{Ga}$ 
levou a uma grande desgaste do cíclotron $C V-28$ e fez com que fosse interrompida a produção deste radioisótopo, e o ${ }^{67} \mathrm{GaCl}_{3}$ começou a ser importado da empresa NORDION (Canadá) ${ }^{(16)}$.

Em 1998 foi adquirido um novo cíclotron, o Cyclone 30 (IBA - Ion Beam Applications - Bélgica), capaz de acelerar prótons com energias entre 15-30 MeV e corrente de feixe de até $350 \mu \mathrm{A}^{(16)}$.

Em 2002 retomou-se a produção semanal do ${ }^{67} \mathrm{Ga}$ que voltou a ser interrompida devido à demanda crescente de ${ }^{18} \mathrm{~F}$ e $0{ }^{67} \mathrm{GaCl}_{3}$ voltou a ser importado da empresa NORDION ${ }^{(16)}$.

A TAB. 4 apresenta as características do ${ }^{67} \mathrm{Ga}$ importado pelo IPEN/CNEN-SP, fornecido pela empresa NORDION ${ }^{(17)}$.

TABELA 4 - Especificações do ${ }^{67}$ Ga importado da empresa NORDION ${ }^{(17)}$

\begin{tabular}{|l|l|}
\hline & \multicolumn{1}{|c|}{ Especificação } \\
\hline Reação Nuclear & ${ }^{68} \mathrm{Zn}(p, 2 n){ }^{67} \mathrm{Ga}$ \\
\hline Forma Química & ${ }^{67} \mathrm{GaCl}_{3}$ em HCl 0,1 mol L \\
\hline Pureza Radionuclídica & $\begin{array}{l}{ }^{67} \mathrm{Ga} \geq 99,4 \% \\
66\end{array}$ \\
& Outros $\leq 0,1 \%$ \\
\hline Pureza Química & $\begin{array}{l}\mathrm{Fe} \leq 0,2 \mu \mathrm{g} / \mathrm{mCi}^{67} \mathrm{Ga} \\
\mathrm{Zn} \leq 0,2 \mu \mathrm{g} / \mathrm{mCi}^{67} \mathrm{Ga} \\
\mathrm{Cu} \leq 0,2 \mu \mathrm{g} / \mathrm{mCi}{ }^{67} \mathrm{Ga}\end{array}$ \\
\hline
\end{tabular}

Em $2011{ }^{\circ}{ }^{67} \mathrm{Ga}$ passou a ser fornecido pela empresa ISORAD (Israel) na forma de Citrato de ${ }^{67} \mathrm{Ga}$, para fracionamento direto, com Pureza Radionuclídica e Radioquímica superiores a $95 \%{ }^{(18)}$.

Quando produzido pelo IPEN-CNEN/SP o ${ }^{67} \mathrm{Ga}$ foi preparado como se segue: preparo de alvos enriquecidos de ${ }^{68} \mathrm{Zn}$ por eletrodeposição em substrato de cobre niquelado; irradiação; dissolução total do alvo em $13 \mathrm{~mL}$ de $\mathrm{HCl}$ concentrado; percolação da solução em resina catiônica DOWEX 50W-X8, 200-400 mesh, condicionada em HCl 10 
$\mathrm{mol} \mathrm{L}^{-1}$; eluição de zinco, níquel e cobre em $\mathrm{HCl} 10 \mathrm{~mol} \mathrm{~L}^{-1}$; eluição de ferro em $\mathrm{HCl} \mathrm{3,5}$ mol L ${ }^{-1}$; eluição de ${ }^{67} \mathrm{Ga}$ em $\mathrm{HCl} 3,5 \mathrm{~mol} \mathrm{~L}^{-1}$. O processo apresentava rendimento de $80 \%{ }^{(19)}$.

Uma vez na forma de ${ }^{67} \mathrm{GaCl}_{3}$, a preparação do citrato era feita como se segue: solução de ${ }^{67} \mathrm{GaCl}_{3}$ levada à secura; adição de $2 \mathrm{~mL}$ de peróxido de hidrogênio $30 \%$, para remoção do resíduo orgânico; nova secura; adição de $3 \mathrm{~mL}$ de água purificada; nova secura; adição de citrato de sódio 3,8\%; fracionamento da solução de Citrato de ${ }^{67} \mathrm{Ga}$; esterilização em autoclave a $121^{\circ} \mathrm{C}$ por 20 minutos ${ }^{(19)}$.

Por se tratar de alvo enriquecido em ${ }^{68} \mathrm{Zn}$, de custo elevado, a solução resultante da percolação com $\mathrm{HCl} 10$ mol. $\mathrm{L}^{-1}$ deve ser recuperada a partir de uma nova eletrodeposição do ${ }^{68} \mathrm{Zn}{ }^{(19)}$.

O Controle de Qualidade envolve vários ensaios específicos que asseguram a pureza, potência, identidade do produto, segurança biológica e eficácia dos radiofármacos. Todos os procedimentos de controle de qualidade que são aplicados aos fármacos não radioativos - como esterilidade, apirogenicidade, $\mathrm{pH}$, características organolépticas, pureza química - são igualmente aplicados aos radiofármacos, com o acréscimo dos ensaios de pureza radioquímica e radionuclídica.

Conforme a Farmacopéia Americana [United State Pharmacopeia (USP)] a solução final de citrato de ${ }^{67} \mathrm{Ga}$ deve ser estéril, apirogênica, apresentar pureza radioquímica superior a $97 \%$ e pureza radionuclídica superior a $99 \%{ }^{(20)}$. 


\section{OBJETIVOS}

O objetivo geral deste trabalho é apresentar uma nova metodologia de obtenção de ${ }^{67} \mathrm{Ga}$, com pureza adequada para utilização na marcação de moléculas para uso em radiodiagnóstico.

O trabalho apresenta como contribuição inédita o desenvolvimento de um método de separação do ${ }^{67} \mathrm{Ga}$ do material alvo a partir da técnica de difusão térmica e sua extração em ácido acético concentrado, sem a necessidade da dissolução total do alvo processo este não descrito na literatura.

O trabalho foi dividido da seguinte maneira:

1) Estudos de difusão térmica e solubilidade em ácido acético concentrado ;

2)Preparação de alvos de zinco natural por eletrodeposição;

3) Irradiações no Cyclone-30;

4) Separação química e purificação do $\operatorname{par}{ }^{67} \mathrm{Ga} / \mathrm{Zn}$;

5) Controle químico, radionuclídico e radioquímico do produto final obtido. 


\section{REVISÃO DA LITERATURA}

\subsection{Utilização do ${ }^{67} \mathrm{Ga}$ em Medicina nuclear}

Os mecanismos pelos quais o gálio é transportado e distribuído no organismo são fundamentais para o entendimento de suas atividades biológicas. Há um conhecimento extensivo sobre o uso do gálio para o diagnóstico de doenças ${ }^{(21)}$.

A primeira utilização do gálio para fins terapêuticos data de 1931, quando LEVADITI e col. estudaram o potencial terapêutico na forma de tartarato de gálio natural para o tratamento de sífilis em coelhos ${ }^{(21)}$.

Após a descoberta do ${ }^{72} \mathrm{Ga}$ (Gálio-72) em produtos de fissão, DUDLEY em 1948 procurou determinar sua presença em materiais biológicos. Ele injetou lactato de ${ }^{72} \mathrm{Ga}$ em ratos e coelhos e observou sua biodistribuição por 60 dias após a administração. Verificou-se acúmulo nos ossos, sugerindo-se o uso para estudos do metabolismo ósseo, excreção renal e a fixação de uma pequena quantidade no fígado e nos rins após 30 $\operatorname{dias}^{(22)}$

Em 1950, DUDLEY preparou o ${ }^{72} \mathrm{Ga}$ na forma de citrato mais facilmente que o lactato. Os experimentos em animais na forma de citrato demonstraram menor captação óssea do que com o lactato de ${ }^{72} \mathrm{Ga}{ }^{(22)}$.

Em 1953 BRUNER e col., HARTMAN e HAYES produziram ${ }^{67} \mathrm{Ga}$ em cíclotron e realizaram experimentos para a melhoria do citrato de ${ }^{67} \mathrm{Ga}$ como traçador ósseo. Observou-se que a concentração de ${ }^{67} \mathrm{Ga}$ nos ossos somente aumentava quando o plasma estava saturado com gálio. Quando o citrato de ${ }^{67} \mathrm{Ga}$ livre de carregador foi administrado, ele foi totalmente captado pelo plasma e não houve captação óssea ${ }^{(22)}$.

Em 1969, EDWARD e HAYES observaram, acidentalmente, que o citrato de ${ }^{67} \mathrm{Ga}$ concentrava-se em tumores de tecidos moles e em locais de inflamação e infecção, 
incluindo sítios de inflamação granulomatosa e sinovite associada com artrite reumatóide ${ }^{(22)}$.

Nos últimos 50 anos $0{ }^{67} \mathrm{Ga}$ tem sido amplamente empregado na técnica de radiodiagnóstico por SPECT.

O principal interesse clínico deriva da observação que as propriedades metabólicas do gálio são similares às do ferro. Ambos apresentam raios iônicos comparáveis e demonstram quase a mesma capacidade de ligação com as proteínas plasmáticas $^{(23)}$.

Os mais importantes carreadores do ferro, transferrina e lactoferrina, não distinguem gálio do ferro, portanto todo gálio no sangue está presente no plasma na forma de complexos com estas proteínas. Sob circunstâncias normais, cerca de um terço das cavidades de transferrina que ligam o ferro são preenchidas, e um grande número de sítios não ocupados estão disponíveis para ligação com o gálio ${ }^{(23)}$.

A lactoferrina apresenta afinidade mais alta com o gálio do que a transferrina. Seu precursor, a apolactoferrina (não contendo átomo metálico), de atividade antibacteriana, está concentrada em muitas secreções epiteliais como leite, fluido seminal, lágrima e secreção nasal. Em focos de inflamação e infeç̧ão, o gálio concentra-se particularmente nos neutrófilos granulosos e leucócitos polimorfonucleares ${ }^{(23)}$.

Uma vasta literatura compartilha o conceito que o complexo ferro (gálio)transferrina é internalizado pelo processo da endocitose. A oxiredutase da membrana plasmática reduz o ferro ligado a transferrina do estado de $\mathrm{Fe}^{3+}$ para $\mathrm{Fe}^{2+}$, facilitando a remoção do ferro da proteína. Como o gálio não existe no estado de valência $2+$, ele não pode seguir o caminho do ferro na célula. A única suposição é a formação do íon pentahidroxi-oxi-gálio $\left[\mathrm{Ga}\left(\mathrm{H}_{2} \mathrm{O}\right)_{5}(\mathrm{OH})\right]^{2+}$, que semelhante ao ferro bivalente é capaz de seguir o mesmo modo de transporte dos íons $\mathrm{Fe}^{2+(23)}$.

Uma vez dentro do citoplasma celular, o gálio liga-se às ferritinas, grandes proteínas que apresentam uma variação de estrutura específica em respeito aos tecidos, dependendo da combinação de suas subunidades. A maior parte da ferritina está concentrada nas células de Kupfer no fígado. Os agregados das moléculas de ferritina com o tempo formam clusters, os quais são degradados após terem sido fagocitados pelos lisossomos. O produto final deste processo, a hemosiderina, é um aglomerado amorfo de proteína desnaturada e lipídeos com intercalações do hidróxido de gálio e seus 
polímeros $^{(23)}$.

Muitos fatores contribuem para a acumulação e retenção do citrato de ${ }^{67} \mathrm{Ga}$ tanto em lesões inflamatórias/infecciosas quanto em diversos tipos de tumores ${ }^{(24,25)}$.

Os dois processos são caracterizados por vasodilatação, aumento do fluxo sanguíneo, aumento da permeabilidade capilar com exsudação de plasma e migração de leucócitos neutrófilos. Quando na circulação, $0{ }^{67} \mathrm{Ga}$ se liga à transferrina circulante na forma iônica, formando um complexo Transferrina $-{ }^{67} \mathrm{Ga}$, chegando ao foco lesionado pelo aumento da permeabilidade capilar ${ }^{(24,25)}$.

Nos processos inflamatórios o ${ }^{67} \mathrm{Ga}$ liga-se à lactoferrina excretada in loco por leucócitos e a sideróforos, produtos de baixo peso molecular produzidos pelas bactérias e com alta afinidade pelo ferro ${ }^{(24,25)}$.

A captação em infecções crônicas é atribuída à afinidade do complexo Lactoferrina- ${ }^{67} \mathrm{Ga}$ por macrófagos e ao tempo de residência relativamente alto do ${ }^{67} \mathrm{Ga}$ no plasma circulante. Outros mecanismos de captação do citrato de gálio em infecções são as ligações em tecidos não específicos resultantes da ruptura da integridade dos tecidos inflamados ${ }^{(24,25)}$.

Em diversos tipos de processos inflamatórios, infecciosos e quadros de febre de origem desconhecida (abdominal, renal, pulmonar, endocardite, osteomielite, infecções pós-transplantes, policrondite, microorganismos) ${ }^{(24,26-35)}$ o radiodiagnóstico com citrato de ${ }^{67} \mathrm{Ga}$ é utilizado para determinar a duração apropriada da terapia antimicrobial e a necessidade de biópsia (com posterior identificação histopatológica) quando aplicável. Em pacientes com leucopenia, ${ }^{67} \mathrm{Ga}$ apresenta melhor sensibilidade que leucócitos marcados com ${ }^{99 \mathrm{~m}} \mathrm{Tc}$.

A cintilografia com citrato de ${ }^{67} \mathrm{Ga}$ mostra-se uma ótima ferramenta na distinção entre a miocardite aguda e o início de um infarto agudo do miocárdio, para que seja estabelecido o tratamento correto o mais rápido possível ${ }^{(36)}$. Em casos de sarcoidose cardíaca associada à taquicardia ventricular a utilização de citrato de ${ }^{67} \mathrm{Ga}$ também colabora para a terapia adequada ${ }^{(37)}$.

A FIG. 2 apresenta a estrutura química do citrato de ${ }^{67} \mathrm{Ga}$. 


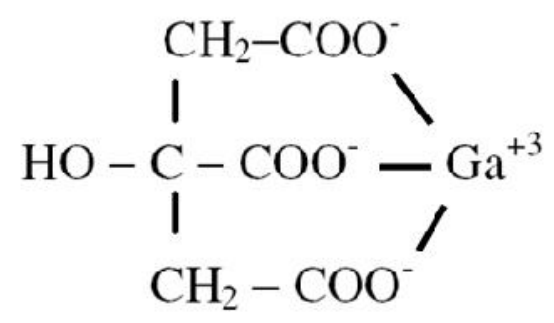

FIGURA 2. Estrutura química do citrato de ${ }^{67} \mathrm{Ga}{ }^{(38)}$

A combinação da cintilografia com citrato de ${ }^{67} \mathrm{Ga}$ e a tomografia computadorizada fornece um diagnóstico completo antes e depois da quimioterapia. A tomografia computadorizada fornece informações sobre a localização e o tamanho do tumor, mas não diferencia as mudanças do pós-tratamento, como fibrose, necrose e inflamações do tumor residual ou recorrente. É utilizado na cintilografia de pacientes com diversos tipos de tumores malignos e benignos, doença de Hodgkin's e linfomas Não-Hodgkin's (25, 39-50).

A endocardite prostética está associada às altas taxas de mortalidade, sendo muitas vezes um desafio seu diagnóstico ${ }^{(34)}$. A FIG. 3 mostra as imagens obtidas por equipamento de SPECT/CT em um paciente que apresentou infecção por Staphylococcus sepsis após cirurgia da válvula aórtica e implante permanente de marca-passo. Após tratamento adequado com antibióticos a infeç̧ão foi erradicada, como mostra a FIG. 4. 


\section{Capítulo $3 \mid 24$ \\ Revisão da Literatura}

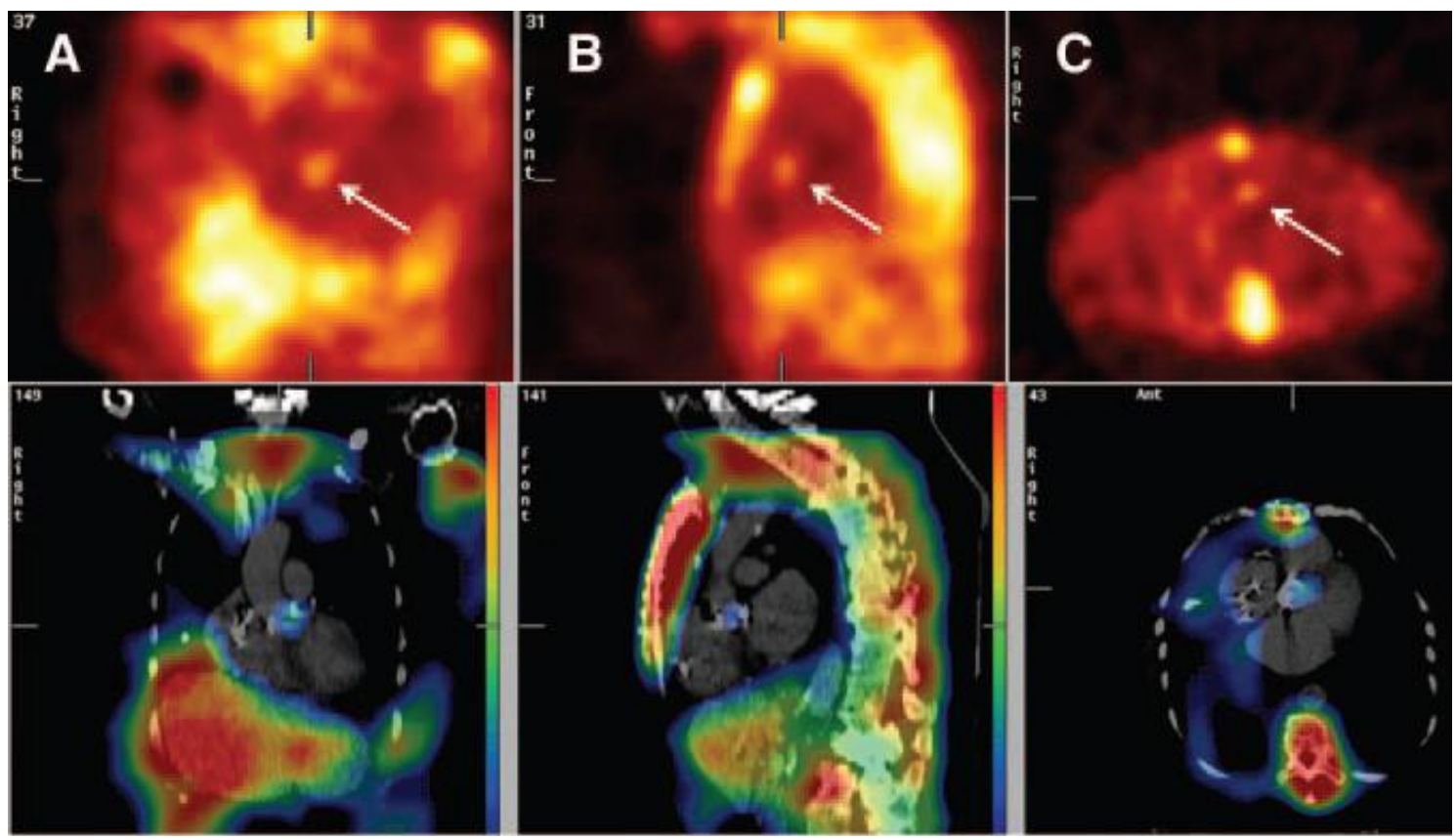

FIGURA 3. Planos coronal (A), sagital (B) e axial (C) de imagem SPECT/CT (Skylight, Philips) obtidas após 48 horas de administração de $150 \mathrm{MBq}$ de citrato de ${ }^{67} \mathrm{Ga}$. A região indicada mostra infecção da prótese da válvula aórtica pós-operatória ${ }^{(34)}$

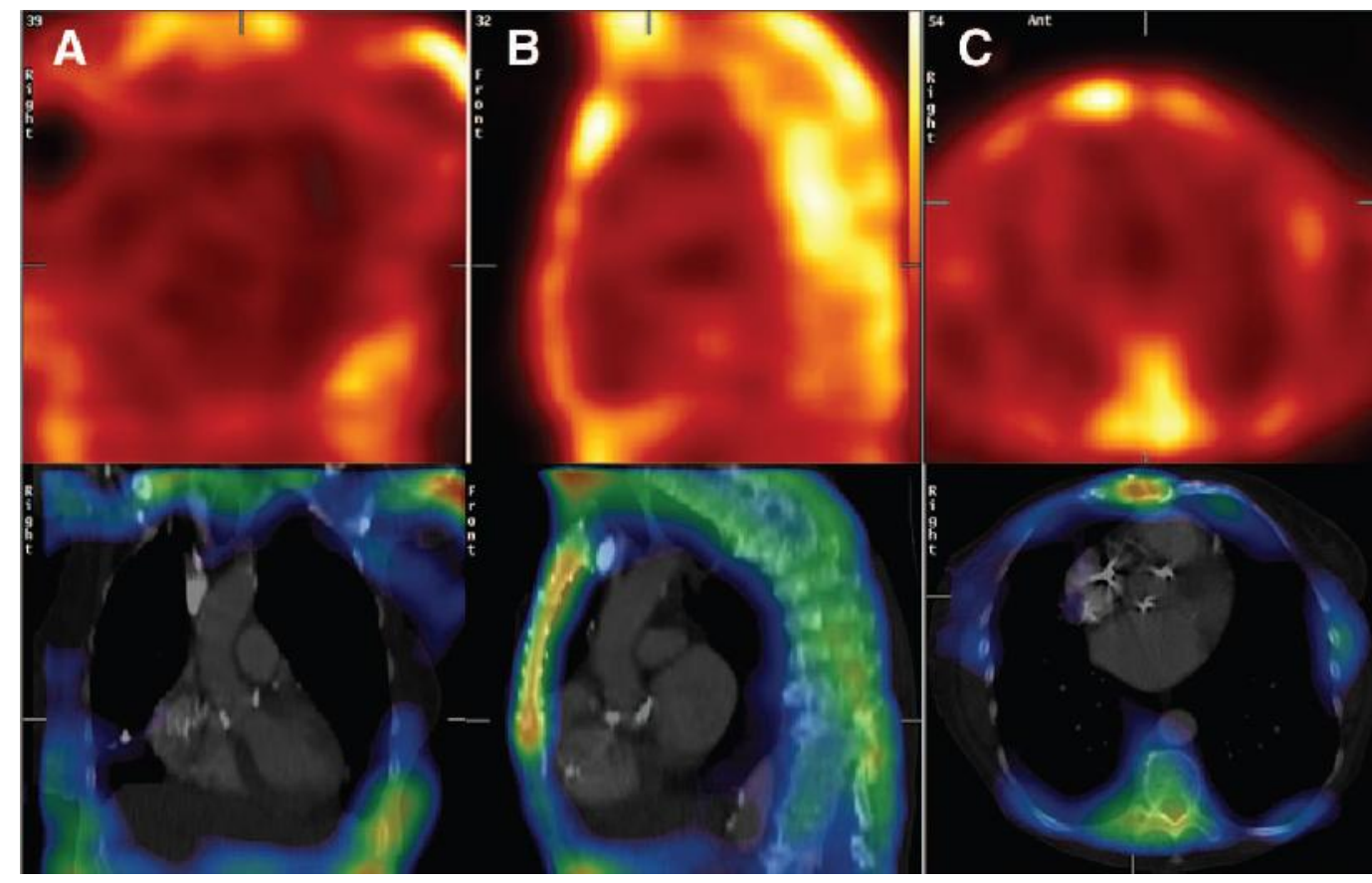

FIGURA 4. SPECT/CT de citrato de ${ }^{67} \mathrm{Ga}$, planos coronal (A), sagital (B) e axial (C), obtidas após o tratamento com antibióticos, indicando o fim da infecção ${ }^{(34)}$ 
Muitas moléculas não se ligam diretamente aos radioisótopos como o ${ }^{67} \mathrm{Ga}$, sendo necessária a utilização de agentes quelantes que sirvam de ligação entre a molécula e o radioisótopo. Estes agentes quelantes são moléculas que contém um grupo funcional capaz de se ligar ao ${ }^{67} \mathrm{Ga}$ ou a outro radiometal e realizar a ponte de ligação com a biomolécula de interesse.

Vários agentes quelantes para marcação com ${ }^{67} \mathrm{Ga}$ tem sido desenvolvidos. Suas propriedades dependem de sua estrutura, carga e lipofilicidade dos complexos formados.

$\mathrm{Na}$ TAB. 5 apresentam-se os principais compostos de ${ }^{67} \mathrm{Ga}$ desenvolvidos e suas utilizações no radiodiagnóstico por SPECT de diversas patologias do organismo humano.

TABELA 5 - Gálio-67: aplicações em medicina nuclear

\begin{tabular}{llc}
\hline \multicolumn{1}{c}{ Produto } & \multicolumn{1}{c}{ Patologia } & Referência \\
\hline${ }^{67}$ Ga-3-Hidroxi-4-Pirididona & Tumores e infecções ósseas & 50,51 \\
${ }^{67}$ Ga-Acetilacetato- & Fibrosarcoma & 52,53 \\
Bis(Tiosemicarbazone) & & 54 \\
${ }^{67}$ Ga-B-Gonadotropina & Tumores de próstata e câncer de mama & \\
${ }_{\text {Corionico Humano }}$ & & $55-57$ \\
${ }^{67}$ Ga-Maltolato, ${ }^{67}$ Ga-N & Carcinoma hepatocelular, linfomas & \\
& Não-Hodgkin's & 58 \\
${ }^{67}$ Ga-DOTA-Bz-Folato & Doenças Inflamatórias & 59 \\
${ }^{67}$ Ga-Lipossomas & Linfoma de Dalton & 60 \\
${ }^{67}$ Ga-Carvão-Ativado & Determinação do Tempo do & \\
& Trânsito Colônico & 61 \\
\hline${ }^{67}$ Ga-DOTA-Bifosfonato & Cintilografia óssea & 62,63 \\
${ }^{67}$ Ga-DOTA-LAN/DOTA-TOC/ & Tumores Neuroendócrinos & 64 \\
${ }^{67}$ Ga - DOTA-Anti-CD20 & Tumores do linfoma Não-Hodgkin & 65 \\
${ }^{67}$ Ga-Anexina5-DOTA & Apoptose & \\
\hline
\end{tabular}




\subsection{Histórico, descoberta e ocorrência do gálio (66-68)}

Previsto e descrito em 1870 por Mendeléev como eka-alumínio, o elemento gálio, foi descoberto em 1875, pelo químico francês Paul-Émile Lecoq de Boisbaudran. A análise espectroscópica de concentrados de blenda (sulfeto de zinco) revelou novas linhas de emissão cuja posição correspondia à prevista para o elemento que faltava na tabela de Mendeléev e que ficava entre o alumínio e o índio. No mesmo ano, foi isolado por Lecoq através da eletrólise do hidróxido de gálio.

Ao novo elemento, Lecoq deu o nome de gálio em honra à sua terra natal, a França, que em latim se denomina Gallia. O descobridor também utilizou um jogo de palavras com seu próprio nome para nomear o elemento: coq em francês significa galo.

É um elemento pouco abundante. A dificuldade de obtê-lo se deve a sua baixa ocorrência em concentrados minerais naturais. Ocorre, em forma de traços, na germanita (minério de germânio, $\mathrm{Cu}_{13} \mathrm{Fe}_{2} \mathrm{Ge}_{2} \mathrm{~S}_{16}$, contendo gálio, zinco e molibdênio como impurezas), na galita (sulfeto de cobre e gálio), no diásporo (hidróxido de alumínio), na blenda (sulfeto de zinco), na bauxita (principal minério do alumínio) e no carvão mineral. A fuligem da queima de alguns tipos de carvão pode ter até 1,5\% de gálio.

\subsection{Propriedades químicas e físico-químicas do gálio}

O gálio é um elemento de propriedades diversificadas. Fisicamente, são conhecidas suas propriedades mecânicas, sua estrutura cristalina (polimorfismo) e suas propriedades termodinâmicas, elétricas, magnéticas e óticas ${ }^{(67,68)}$.

Quimicamente, o elemento gálio é classificado como um metal da família 13 (IIIA) da tabela periódica, entre o alumínio e o índio. O gálio apresenta número atômico 31 e massa atômica $69,72 \mathrm{u}^{(67,68)}$.

Seu estado de oxidação mais estável é $0+3$, porém, identificaram-se estados de oxidação menor, como o +2 e +1 . O gálio metálico é dissolvido lentamente em ácidos e bases e seus sais sofrem hidrólise formando sais básicos, neste aspecto, semelhante ao alumínio ${ }^{(67,68)}$.

$\mathrm{O}$ íon $\mathrm{Ga}^{3+}$ é um ácido forte, e se liga às bases de Lewis fortes, particularmente à hidroxila $\mathrm{OH}^{-}$. Assim, o gálio apresenta uma forte tendência para formação de quelatos através de ligações com oxigênio ${ }^{(23,69)}$. 
A hidrólise do gálio é representada pelas equações de 4 a $8^{(23,69)}$.

$$
\begin{aligned}
& {\left[\mathrm{Ga}\left(\mathrm{H}_{2} \mathrm{O}\right)_{6}\right]^{3+}+\mathrm{H}_{2} \mathrm{O} \leftrightarrow\left[\mathrm{Ga}\left(\mathrm{H}_{2} \mathrm{O}\right)_{5}(\mathrm{OH})\right]^{2+}+\mathrm{H}_{3} \mathrm{O}^{+}} \\
& {\left[\mathrm{Ga}\left(\mathrm{H}_{2} \mathrm{O}\right)_{5}(\mathrm{OH})\right]^{2+}+\mathrm{H}_{2} \mathrm{O} \leftrightarrow\left[\mathrm{Ga}\left(\mathrm{H}_{2} \mathrm{O}\right)_{4}(\mathrm{OH})_{2}\right]^{+}+\mathrm{H}_{3} \mathrm{O}^{+}} \\
& {\left[\mathrm{Ga}\left(\mathrm{H}_{2} \mathrm{O}\right)_{4}(\mathrm{OH})_{2}\right]^{+}+\mathrm{H}_{2} \mathrm{O} \leftrightarrow \mathrm{Ga}(\mathrm{OH})_{3}(\mathrm{~s})+\mathrm{H}_{3} \mathrm{O}^{+}+3 \mathrm{H}_{2} \mathrm{O}} \\
& {\left[\mathrm{Ga}\left(\mathrm{H}_{2} \mathrm{O}\right)_{4}(\mathrm{OH})_{2}\right]^{+}+\mathrm{H}_{2} \mathrm{O} \leftrightarrow \mathrm{Ga}(\mathrm{OH})_{3}\left(\mathrm{H}_{2} \mathrm{O}\right)_{3}^{+}+\mathrm{H}_{3} \mathrm{O}^{+}} \\
& \mathrm{Ga}(\mathrm{OH})_{3}(\mathrm{aq})+\mathrm{H}_{2} \mathrm{O} \leftrightarrow\left[\mathrm{Ga}(\mathrm{OH})_{4}\right]^{-}
\end{aligned}
$$

O íon $\mathrm{Ga}^{3+}$ “livre” apresenta coordenação octaédrica, com 6 moléculas de água. As moléculas de água são substituídas, em etapas, pelos grupos $\mathrm{OH}^{-}$, com simultânea produção de íons hidrônio, resultando em uma solução ácida. O cátion $\left[\mathrm{Ga}\left(\mathrm{H}_{2} \mathrm{O}\right)_{6}\right]^{3+}$ pode atuar como doador de próton resultando em $\left[\mathrm{Ga}\left(\mathrm{H}_{2} \mathrm{O}\right)_{5}(\mathrm{OH})\right]^{2+},\left[\mathrm{Ga}\left(\mathrm{H}_{2} \mathrm{O}\right)_{4}(\mathrm{OH})_{2}\right]^{+}$, etc. Em $\mathrm{pH} 2$, uma fase amorfa de $\mathrm{Ga}(\mathrm{OH})_{3}$ precipita (equação 6) e o gálio remanescente, segue a via de hidrólise (equação 7) ${ }^{(23,69)}$.

Com o aumento gradual do $\mathrm{pH}$, a desprotonação das espécies mononucleares leva a precipitação do hidróxido, $\mathrm{Ga}(\mathrm{OH})_{3}$, e um aumento maior do $\mathrm{pH}$ permite a formação do $\mathrm{GaO}(\mathrm{OH})$ cristalino. Esta forma cristalina é solúvel em soluções básicas com a formação do íon gallato, $\left[\mathrm{Ga}(\mathrm{OH})_{4}\right]^{-}$. Em pH 7,4, 98,4\% do gálio aquoso está nesta forma ${ }^{(69)}$.

Assim existem duas formas iônicas de gálio adequadas para processos bioquímicos metabólicos: $\left[\mathrm{Ga}\left(\mathrm{H}_{2} \mathrm{O}\right)_{5}(\mathrm{OH})\right]^{2+}$ em meio ácido fraco e $\left[\mathrm{Ga}(\mathrm{OH})_{4}\right]^{-}$em soluções alcalinas e neutras ${ }^{(23)}$.

O raio iônico do $\mathrm{Ga}^{+3}$ em coordenação tetraédrica é 61 pm e 76 pm em coordenação octaédrica, então é um análogo do $\mathrm{Fe}^{+3}(69 \mathrm{pm})$ e do $\mathrm{Al}^{+3}(67,5 \mathrm{pm})$, particularmente em combinação com o fósforo. A afinidade do gálio com o fósforo é tão alta que os fosfatos de gálio são compostos altamente estáveis ${ }^{(22)}$. As principais propriedades físico-químicas do gálio estão relacionadas na TAB. $6^{(70)}$. 
TABELA 6 - Propriedades físico-químicas do gálio ${ }^{(70)}$

\begin{tabular}{|c|c|}
\hline PROPRIEDADES & \\
\hline Número atômico & 31 \\
\hline Massa atômica & $69,723 \mathrm{~g} \cdot \mathrm{mol}^{-1}$ \\
\hline Configuração eletrônica & {$[A r] 4 s^{2} 3 d^{10} 4 p^{1}$} \\
\hline Densidade $\left(0^{\circ} \mathrm{C}\right)$ & $904 \mathrm{~kg} \cdot \mathrm{m}^{-3}$ \\
\hline Ponto de fusão & $29,76^{\circ} \mathrm{C}$ \\
\hline Ponto de ebulição & $2403^{\circ} \mathrm{C}$ \\
\hline Resistividade elétrica $\left(20^{\circ} \mathrm{C}\right)$ & $14 \mathrm{~m} \Omega \mathrm{cm}$ \\
\hline Estrutura cristalina $\left(20^{\circ} \mathrm{C}\right)$ & Ortorrômbica \\
\hline Raio atômico empírico & $130 \mathrm{pm}$ \\
\hline Raio iônico & Tetraédrica - $61 \mathrm{pm}$ \\
\hline & Octaédrica - 76 pm \\
\hline Energia de ionização & 1 a $578,8 \mathrm{~kJ} \mathrm{~mol}^{-1}$ \\
\hline & 2 a $1979,3 \mathrm{~kJ} \mathrm{~mol}^{-1}$ \\
\hline & 3a $2963{\mathrm{~kJ} . \mathrm{mol}^{-1}}^{-1}$ \\
\hline & 4a $6180 \mathrm{~kJ}^{\mathrm{a}} \mathrm{mol}^{-1}$ \\
\hline Dureza & 1,5 \\
\hline Eletronegatividade & 1,81 Pauling \\
\hline Condutividade térmica & $29 \mathrm{~W} \cdot \mathrm{m}^{-1} \cdot{ }^{\circ} \mathrm{C}^{-1}$ \\
\hline Calor específico (20 ㄷ) & $371 \mathrm{~J} \cdot \mathrm{kg}^{-1} \cdot{ }^{\circ} \mathrm{C}^{-1}$ \\
\hline Entalpia de fusão & $5,59 \mathrm{~kJ}_{\mathrm{mol}}^{-1}$ \\
\hline Entalpia de vaporização & $256{\mathrm{~kJ} . \mathrm{mol}^{-1}}^{-1}$ \\
\hline Entalpia de atomização & $277 \mathrm{~kJ} \cdot \mathrm{mol}^{-1}$ \\
\hline Estados de oxidação & $+3,+2,+1$ \\
\hline
\end{tabular}

O gálio metálico apresenta propriedades físicas particulares. Ele funde a $29,75{ }^{\circ} \mathrm{Ce}$ seu ponto de ebulição é alto, $2403{ }^{\circ} \mathrm{C}$. Diante desta propriedade, o seu uso em termômetros foi a primeira aplicação encontrada, devido à extensa faixa de temperatura em que permanece líquido. No entanto, seu uso deve ser associado aos capilares de 
quartzo, para que possa ser utilizado em altas temperaturas ${ }^{(67)}$.

O gálio, diferente de outros metais, se expande quando se solidifica $(3,4 \%$ de expansão), mostrando os cuidados necessários quanto ao seu armazenamento ${ }^{(67)}$.

Um dos usos mais comuns se deve as suas propriedades termodinâmicas, podendo ser empregado como um fluido eficiente de transmissão de calor ${ }^{(67)}$.

O gálio associado ao arsênio, antimônio e fósforo, forma uma liga intermetálica semicondutora, com grande e variada faixa de propriedades, desde as metálicas até as isolantes ${ }^{(67)}$.

Os semicondutores de gálio, principalmente o arseneto de gálio, são amplamente utilizados na indústria eletrônica, no desenvolvimento de lasers de alta eficiência aplicados em telecomunicações, no desenvolvimento de componentes para supercomputadores, na fabricação de transistores de alta temperatura e baterias solares $^{(67)}$.

\subsection{Propriedades físicas e nucleares do gálio}

O gálio natural consiste em uma mistura de dois isótopos estáveis: gálio-69 $(60,4 \%)$ e gálio-71 $(39,6 \%)^{(70)}$.

São conhecidos 25 radioisótopos de gálio, com números de massa entre 60 e 86 . Destes, apenas ${ }^{66} \mathrm{Ga},{ }^{67} \mathrm{Ga}$ e ${ }^{68} \mathrm{Ga}$ apresentam características físicas e decaimento favorável com interesse clínico ${ }^{(71,72)}$.

Radioisótopos de gálio são estudados e avaliados desde 1946 quando se descobriu $\mathrm{o}^{72} \mathrm{Ga}$ em produtos de fissão ${ }^{(22)}$.

Em 1953, BRUNER e col. observaram duas desvantagens do ${ }^{72} \mathrm{Ga}$ : a produção do radionuclídeo em reator apresentava baixa atividade específica, com alta concentração de ${ }^{71} \mathrm{Ga}$ como carregador e o $\mathrm{t}_{1 / 2}$ de 14 horas, o que não permitia estudos mais tardios. Preparou-se $0{ }^{67} \mathrm{Ga}$, livre de carregador, em cíclotron, pelo bombardeamento de zinco natural com prótons de $25 \mathrm{MeV}^{(22)}$.

$\mathrm{Na}$ TAB. 7 apresentam-se os radioisótopos conhecidos de gálio, suas massas, $\mathrm{t}_{1 / 2} \mathrm{e}$ tipo de decaimento ${ }^{(71)}$. 
TABELA 7 - Radioisótopos de gálio ${ }^{(71)}$

\begin{tabular}{|c|c|c|c|c|}
\hline Símbolo & Massa & $\begin{array}{c}\text { Meia-Vida } \\
\text { Física }\end{array}$ & Decaimento & $\begin{array}{l}\text { Produto de } \\
\text { Decaimento }\end{array}$ \\
\hline \multirow[t]{2}{*}{${ }^{60} \mathrm{Ga}$} & 59,9571 & $70 \mathrm{~ms}$ & $\beta^{+}$ & ${ }^{60} \mathrm{Zn}$ \\
\hline & & & $\beta^{+}, p$ & ${ }^{59} \mathrm{Cu}$ \\
\hline${ }^{61} \mathrm{Ga}$ & 60,9495 & $0,15 \mathrm{~s}$ & $\beta^{+}$ & ${ }^{61} \mathrm{Zn}$ \\
\hline${ }^{62} \mathrm{Ga}$ & 61,9442 & $116,18 \mathrm{~ms}$ & $\beta^{+}$ & ${ }^{62} \mathrm{Zn}$ \\
\hline${ }^{63} \mathrm{Ga}$ & 62,9393 & $32,4 \mathrm{~s}$ & $\beta^{+}$ & ${ }^{63} \mathrm{Zn}$ \\
\hline${ }^{64} \mathrm{Ga}$ & 63,9368 & $2,63 \mathrm{~min}$ & $\beta^{+}$ & ${ }^{64} \mathrm{Zn}$ \\
\hline${ }^{65} \mathrm{Ga}$ & 64,9394 & $15,2 \mathrm{~min}$ & $\beta^{+}$ & ${ }^{65} \mathrm{Zn}$ \\
\hline${ }^{66} \mathrm{Ga}$ & 65,9316 & $9,5 \mathrm{~h}$ & $\beta^{+}$ & ${ }^{66} \mathrm{Zn}$ \\
\hline${ }^{67} \mathrm{Ga}$ & 66,9282 & $3,26 d$ & CE & ${ }^{67} \mathrm{Zn}$ \\
\hline${ }^{68} \mathrm{Ga}$ & 67,9280 & $1,13 \mathrm{~h}$ & $\beta^{+}$ & ${ }^{68} \mathrm{Zn}$ \\
\hline${ }^{69} \mathrm{Ga}$ & 68,9256 & Estável & - & \\
\hline \multirow[t]{2}{*}{${ }^{70} \mathrm{Ga}$} & 69,9260 & $21,1 \mathrm{~min}$ & CE & ${ }^{70} \mathrm{Zn}$ \\
\hline & & & $\beta^{-}$ & ${ }^{70} \mathrm{Ge}$ \\
\hline${ }^{71} \mathrm{Ga}$ & 70,9247 & Estável & - & \\
\hline${ }^{72} \mathrm{Ga}$ & 71,9264 & $14,1 \mathrm{~h}$ & $\beta^{-}$ & ${ }^{72} \mathrm{Ge}$ \\
\hline${ }^{73} \mathrm{Ga}$ & 72,9252 & $4,87 \mathrm{~h}$ & $\beta^{-}$ & ${ }^{73} \mathrm{Ge}$ \\
\hline${ }^{74} \mathrm{Ga}$ & 73,9269 & $8,12 \mathrm{~min}$ & $\beta^{-}$ & ${ }^{74} \mathrm{Ge}$ \\
\hline${ }^{75} \mathrm{Ga}$ & 74,9265 & $126 \mathrm{~s}$ & $\beta^{-}$ & ${ }^{75} \mathrm{Ge}$ \\
\hline${ }^{76} \mathrm{Ga}$ & 75,9288 & $32,6 \mathrm{~s}$ & $\beta^{-}$ & ${ }^{76} \mathrm{Ge}$ \\
\hline${ }^{77} \mathrm{Ga}$ & 76,9292 & $13,2 \mathrm{~s}$ & $\beta^{-}$ & ${ }^{77} \mathrm{Ge}$ \\
\hline${ }^{78} \mathrm{Ga}$ & 77,9316 & $5,09 \mathrm{~s}$ & $\beta^{-}$ & ${ }^{78} \mathrm{Ge}$ \\
\hline${ }^{79} \mathrm{Ga}$ & 78,9329 & $2,85 \mathrm{~s}$ & $\beta^{-}$ & ${ }^{79} \mathrm{Ge}$ \\
\hline \multirow[t]{2}{*}{${ }^{80} \mathrm{Ga}$} & 79,9365 & $1,70 \mathrm{~s}$ & $\beta^{-}$ & ${ }^{80} \mathrm{Ge}$ \\
\hline & & & $\beta^{-}, \mathrm{n}$ & ${ }^{79} \mathrm{Ge}$ \\
\hline \multirow[t]{2}{*}{${ }^{81} \mathrm{Ga}$} & 80,9378 & $1,22 \mathrm{~s}$ & $\beta^{-}$ & ${ }^{81} \mathrm{Ge}$ \\
\hline & & & $\beta, n$ & ${ }^{80} \mathrm{Ge}$ \\
\hline
\end{tabular}




\begin{tabular}{ccccc}
${ }^{82} \mathrm{Ga}$ & 81,9430 & $0,60 \mathrm{~s}$ & $\beta^{-}$ & ${ }^{82} \mathrm{Ge}$ \\
& & $\beta^{-}, \mathrm{n}$ & ${ }^{81} \mathrm{Ge}$ \\
${ }^{83} \mathrm{Ga}$ & 82,9470 & $308 \mathrm{~ms}$ & $\beta^{-}$ & ${ }^{83} \mathrm{Ge}$ \\
& & $\beta^{-}, \mathrm{n}$ & ${ }^{82} \mathrm{Ge}$ \\
${ }^{84} \mathrm{Ga}$ & 83,9527 & $85 \mathrm{~ms}$ & $\beta^{-}$ & ${ }^{84} \mathrm{Ge}$ \\
& & & $\beta^{-}, \mathrm{n}$ & ${ }^{83} \mathrm{Ge}$ \\
${ }^{85} \mathrm{Ga}$ & 84,9570 & $50 \mathrm{~ms}$ & & \\
${ }^{86} \mathrm{Ga}$ & 85,9631 & $30 \mathrm{~ms}$ & & \\
\hline
\end{tabular}

O ${ }^{67} \mathrm{Ga}$ decai $100 \%$ por captura eletrônica para $0{ }^{67} \mathrm{Zn}$ estável. Seu decaimento inclui a emissão de raios $\gamma$ com energias de 93,3 keV (37\%), 184,6 keV (20,4\%), 300,2 keV $(16,6 \%)^{(73)}$, conforme ilustrado na FIG. $5^{(74)}$.

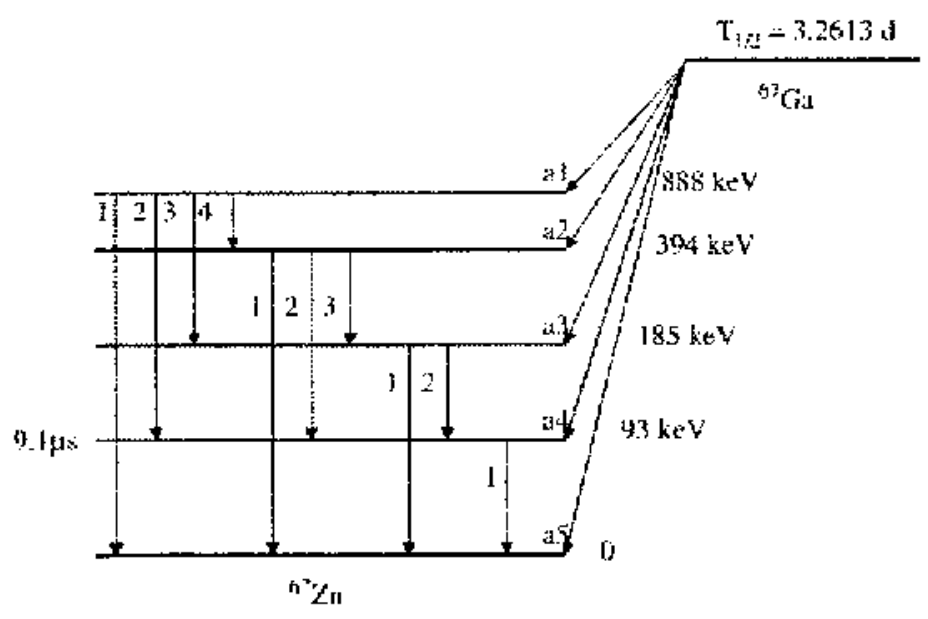

FIGURA 5 - Esquema de decaimento do ${ }^{67} \mathrm{Ga}{ }^{(74)}$

Na TAB. 8 e na TAB. 9 são apresentadas as energias dos elétrons e dos fótons emitidos pelo decaimento do ${ }^{67} \mathrm{Ga}{ }^{(73)}$. 
TABELA 8 - EMISSÃO DE ELÉTRONS PRODUZIDOS PELO DECAIMENTO DO ${ }^{67} \mathrm{GA}{ }^{(73)}$

\begin{tabular}{cc}
\hline Fração & Energia (keV) \\
\hline 0,010853 & 93,175 \\
0,032844 & 92,117 \\
0,268110 & 83,652 \\
0,602060 & 7,530 \\
1,648900 & 0,099 \\
\hline
\end{tabular}

TABELA 9 - Emissão de fótons produzidos pelo decaimento do ${ }^{67} \mathrm{Ga}{ }^{(73)}$

\begin{tabular}{cc}
\hline Fração & Energia (keV) \\
\hline 0,022420 & 208,950 \\
0,028560 & 91,266 \\
0,044768 & 393,530 \\
0,065838 & 9,570 \\
0,159940 & 300,220 \\
0,164720 & 8,616 \\
0,197060 & 184,580 \\
0,322970 & 8,639 \\
\hline 0,357000 & 93,311 \\
\hline
\end{tabular}

$\mathrm{O}^{67} \mathrm{Ga}$ é produzido em cíclotron a partir do bombardeamento de alvos de ${ }^{\text {nat }} \mathrm{Zn}$ (Zinco Natural), ${ }^{64,66,68} \mathrm{Zn}$ (Zinco-64, 66, 68), ${ }^{65} \mathrm{Cu}$ (Cobre-65), ${ }^{\text {nat }}$ Ge (Germânio Natural) ou ${ }^{59} \mathrm{Co}$ (Cobalto-59) com prótons, dêuterons, partículas $\alpha,{ }^{11} \mathrm{~B}$ (Boro-11) ou ${ }^{12} \mathrm{C}$ (Carbono12). As principais reações nucleares para sua produção estão relacionadas na TAB. 10. 
TABELA 10 - Reações nucleares para produção de ${ }^{67} \mathrm{Ga}$

\begin{tabular}{lcc}
\hline \multicolumn{1}{c}{ Reação Nuclear } & Energia Incidente (MeV) & Referência \\
\hline${ }^{67} \mathrm{Zn}(p, n){ }^{67} \mathrm{Ga}$ & $12-100$ & $22,72,79,81$ \\
${ }^{68} \mathrm{Zn}(p, 2 n){ }^{67} \mathrm{Ga}$ & $18-100$ & $22,72,75,81,82$ \\
${ }^{n a t} \mathrm{Ge} /{ }^{\text {nat }} \mathrm{Zn}(p, 2 n){ }^{67} \mathrm{Ga}$ & $30-100$ & 77 \\
${ }^{67} \mathrm{Zn}(d, 2 n){ }^{67} \mathrm{Ga}$ & $8-19$ & $22,72,75,80$ \\
${ }^{66} \mathrm{Zn}(d, n){ }^{67} \mathrm{Ga}$ & $8-16$ & $22,72,75,80$ \\
${ }^{68} \mathrm{Zn}(d, 3 n){ }^{67} \mathrm{Ga}$ & 19 & 80 \\
${ }^{65} \mathrm{Cu}(\alpha, 2 n){ }^{67} \mathrm{Ga}$ & $16-30$ & $22,72,79$ \\
${ }^{64} \mathrm{Zn}(\alpha, p){ }^{67} \mathrm{Ga}$ & $13-40$ & 76 \\
${ }^{66} \mathrm{Zn}(\alpha, p 2 n){ }^{67} \mathrm{Ga}$ & 40 & 72 \\
${ }^{64} \mathrm{Zn}(\alpha, n){ }^{67} \mathrm{Ge} \rightarrow{ }^{67} \mathrm{Ga}$ & $13-21$ & 78 \\
${ }^{59} \mathrm{Co}\left({ }^{11} \mathrm{~B}, 3 n\right){ }^{67} \mathrm{Ge} \rightarrow{ }^{67} \mathrm{Ga}$ & 55 & 78 \\
${ }^{59} \mathrm{Co}\left({ }^{12} \mathrm{C}, 3 n\right){ }^{67} \mathrm{As} \rightarrow{ }^{67} \mathrm{Ge} \rightarrow{ }^{67} \mathrm{Ga}$ & 75 & 76 \\
\hline
\end{tabular}

Nas FIG. 6 e FIG. 7 apresentam-se os gráficos das funções de excitação, com as seções de choque em função da energia dos prótons, para as reações nucleares ${ }^{67} \mathrm{Zn}(p$, $n)^{67} \mathrm{Ga} \mathrm{e}{ }^{68} \mathrm{Zn}(p, 2 n){ }^{67} \mathrm{Ga}$, respectivamente ${ }^{(73)}$.

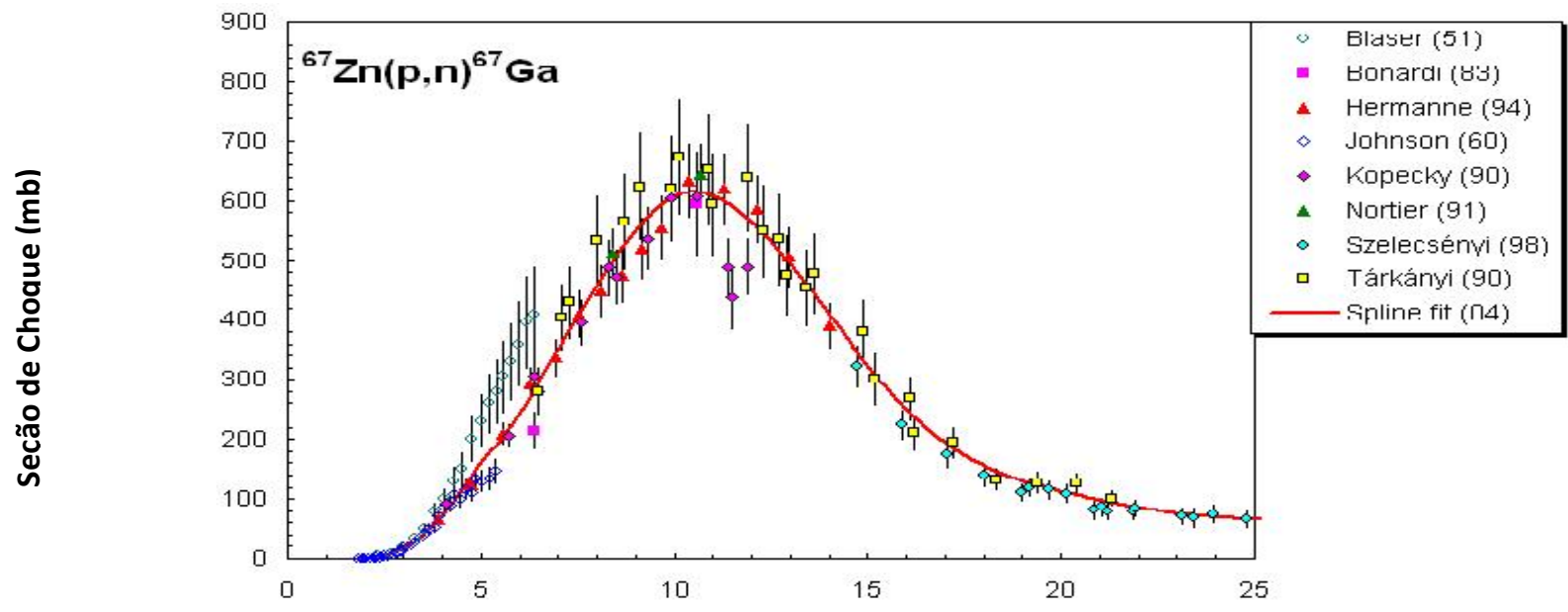

Energia (MeV)

FIGURA 6 - Função de excitação para a reação ${ }^{67} \mathrm{Zn}(p, n){ }^{67} \mathrm{Ga}{ }^{(73)}$ 


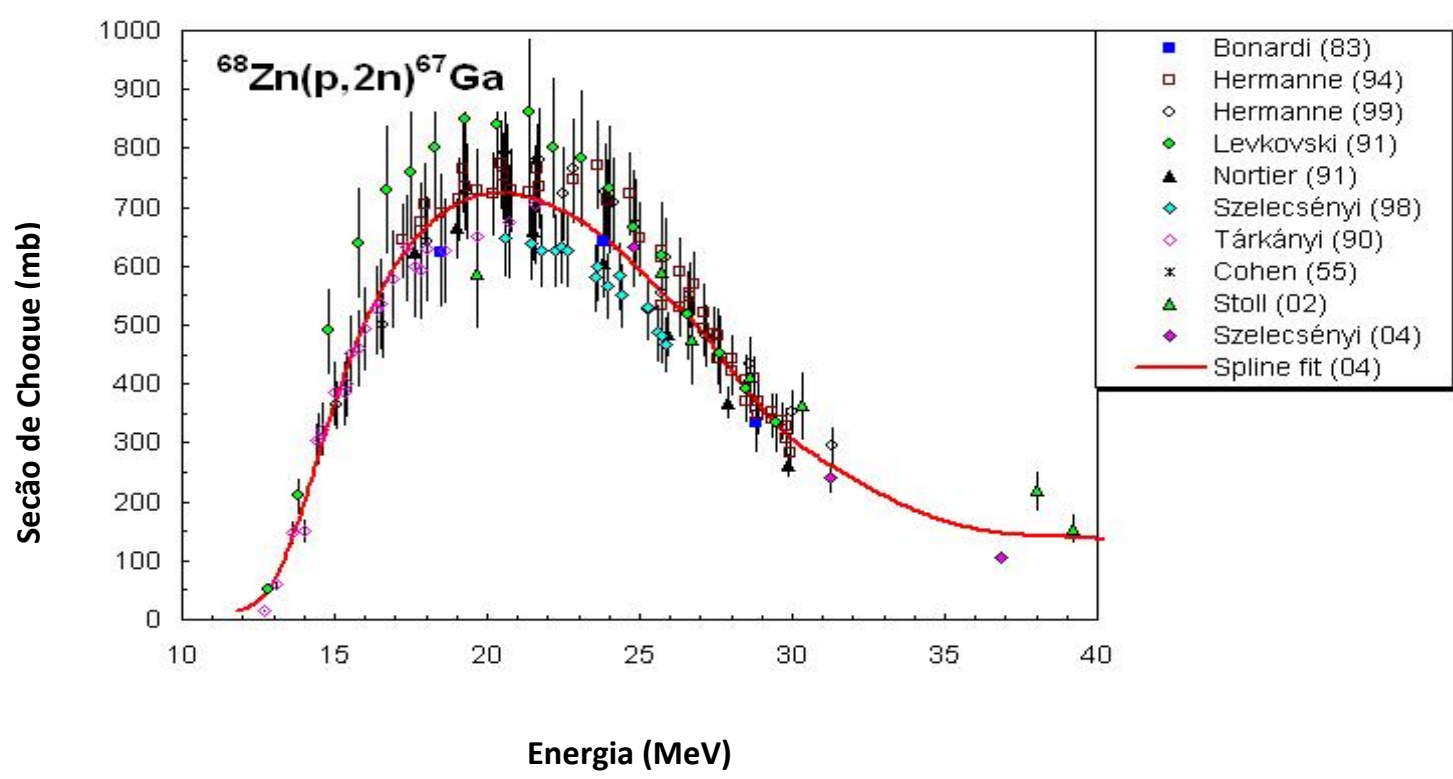

FIGURA 7 - Função de excitação para a reação ${ }^{68} \mathrm{Zn}(p, 2 n){ }^{67} \mathrm{Ga}{ }^{(73)}$

As duas reações nucleares mais largamente utilizadas para produzir ${ }^{67} \mathrm{Ga}$ mostradas acima, apresentam energias limiares diferentes. O rendimento máximo de produção ocorre para energias entre 10 e $20 \mathrm{MeV}$ para a reação $(p, n)$ e entre 15 e 30 MeV para a reação $(p, 2 n)$.

A reação $(p, 2 n)$ tem uma seção de choque maior, de modo que a quantidade de ${ }^{67} \mathrm{Ga}$ produzida é maior, sendo esta reação a mais empregada para a produção rotineira de ${ }^{67} \mathrm{Ga}$.

\subsection{Métodos de separação do ${ }^{67}$ Ga dos materiais alvos}

Os processos utlizados para separação do ${ }^{67} \mathrm{Ga}$ dos materiais alvos e sua purificação para utilização em Medicina Nuclear são descritos a seguir.

\subsubsection{Métodos utilizando a extração por solventes}

Um dos métodos clássicos para extração de radioisótopos dos alvos de irradiação é a extração por solventes. Nesta técnica, o alvo é totalmente dissolvido em uma solução 
ácida ou básica, e o radioisótopo é extraído utilizando um solvente orgânico. Alguns processos de extração por solventes são altamente específicos, com a transferência do composto de interesse preferencialmente da fase aquosa para a fase orgânica ${ }^{\left({ }^{(8)}\right.}$.

É possível alterar as condições do sistema de extração por solvente de modo que o elemento a ser separado retorne para a fase aquosa. Esta "reversão" pode atuar tanto no aumento da especificidade da operação de extração, como para retornar a substância de interesse para um meio mais conveniente para purificação adicional ${ }^{(8)}$.

Em 1970, HUPF e BEAVER ${ }^{(83)}$ produziram ${ }^{67} \mathrm{Ga}$ pela reação ${ }^{68} \mathrm{Zn}(p, 2 n){ }^{67} \mathrm{Ga}$, a partir de alvos de zinco na forma de tubo e na forma eletrodepositada em placas de prata/cobre. Após a irradiação, os alvos foram dissolvidos em $\mathrm{HCl} 5 \mathrm{~mol} \mathrm{~L}^{-1}$. A extração do ${ }^{67} \mathrm{Ga}$ foi realizada como segue: lavagem da solução de dissolução do alvo com 3 porções de metil-isobutil-cetona, lavagem da fase orgânica com 3 porções de $\mathrm{HCl} 6 \mathrm{~mol} \mathrm{~L}^{-1}$ (para remoção do zinco), lavagem da fase orgânica com 3 porções de água para extração do ${ }^{67} \mathrm{Ga}$ e redução do volume para $5 \mathrm{~mL}$ da solução de ${ }^{67} \mathrm{Ga}$. A solução foi carregada em uma coluna de troca aniônica Bio-Rad AG-1X2 e o ${ }^{67} \mathrm{Ga}$ foi eluído em solução de $\mathrm{HCl} 2 \mathrm{~mol} \mathrm{~L}^{-1}$ enquanto os traços de zinco permaneceram retidos na resina. Este processamento durou 12 horas e a recuperação do ${ }^{67} \mathrm{Ga}$ foi de aproximadamente $90 \%$. A análise química apresentou 8 e $6 \mu \mathrm{g} \mathrm{mL}^{-1}$ de ferro e zinco, respectivamente.

BROWN ${ }^{(84)}$ em 1971, produzindo ${ }^{67} \mathrm{Ga}$ do mesmo modo que HUPF e BEAVER, melhorou a purificação do ${ }^{67} \mathrm{Ga}$, tanto em relação à pureza do produto final, quanto em relação ao tempo de processamento químico que passou de 12 horas para 2 horas. Este procedimento utilizou $\mathrm{HCl} 7 \mathrm{~mol} \mathrm{~L}^{-1}$ e extração por solvente com éter diisopropílico, que demonstrou ser mais específico para extração do ${ }^{67} \mathrm{Ga}$. Foi excluída a utilização de coluna de troca aniônica para retenção do zinco. A concentração de ferro e zinco foi inferior a 1 $\mu \mathrm{g} \mathrm{mL} \mathrm{L}^{-1}$.

Em 1972, DAHL e TILBURY ${ }^{(85)}$ produziram ${ }^{67} \mathrm{Ga}$ a partir da reação ${ }^{67} \mathrm{Zn}(d, 2 n){ }^{67} \mathrm{Ga}$, utilizando alvos de zinco eletrodepositados em prata/cobre. O alvo foi processado como segue: dissolução do alvo em HCl $8 \mathrm{~mol} \mathrm{~L}^{-1}$, extração do ${ }^{67} \mathrm{Ga}$ com 3 porções de $25 \mathrm{~mL}$ de éter diisopropílico, reversão com $\mathrm{HCl} 8 \mathrm{~mol} \mathrm{~L}^{-1}$ e 2 porções de $7,5 \mathrm{~mL}$ de água purificada para extração do ${ }^{67} \mathrm{Ga}$. A solução aquosa foi evaporada e o resíduo foi retomado em citrato de sódio $3 \%$.

BROWN e colab. ${ }^{(86)}$ em 1973, utilizaram alvos de ${ }^{68} \mathrm{Zn}$ eletrodepositados em 
níquel, em substrato de cobre $\left[{ }^{68} \mathrm{Zn}(p, 2 n){ }^{67} \mathrm{Ga}\right]$. A difusão do níquel sobre o cobre impede a formação da liga metálica $\mathrm{Zn}-\mathrm{Cu}$, evitando a contaminação da câmara de vácuo onde fica o porta-alvo, facilitando a separação e purificação do ${ }^{67} \mathrm{Ga}$ produzido e impedindo a reação ${ }^{65} \mathrm{Cu}(p, n){ }^{65} \mathrm{Zn}$, que contamina o ${ }^{67} \mathrm{Ga}$ e o ${ }^{68} \mathrm{Zn}$.

A purificação do ${ }^{67} \mathrm{Ga}$ utilizando éter diisopropílico implementada pelo próprio BROWN ${ }^{(84)}$ foi modificada. Após a irradiação, o alvo foi dissolvido com $100 \mathrm{~mL}$ de $\mathrm{HCl} 7$ mol $L^{-1}$ e antes da extração por solvente, algumas alterações foram feitas: limpeza em ultra-som para acelerar a dissolução, adição de 5 gotas de peróxido de hidrogênio $30 \%$ ao $\mathrm{HCl} 7 \mathrm{~mol} \mathrm{L^{-1 }}$ para acelerar a dissolução dos sólidos e aquecimento da solução final para decomposição do peróxido de hidrogênio.

VLATKOVIC e colab. ${ }^{(75)}$ em 1975 , obtiveram ${ }^{67} \mathrm{Ga}$ com as reações ${ }^{67} \mathrm{Zn}(d, 2 n){ }^{67} \mathrm{Ga}$ e ${ }^{66} \mathrm{Zn}(d, n){ }^{67} \mathrm{Ga}$. A purificação foi realizada 2-3 dias após a produção para decaimento do ${ }^{66} \mathrm{Ga}$. O alvo foi lavado em água purificada, acetona e tetraclorometano, dissolvido em $\mathrm{HNO}_{3}$ concentrado, evaporado até a secura, adicionado $\mathrm{HCl}$ concentrado e evaporado novamente até a secura. $\mathrm{O}$ resíduo foi dissolvido em uma mistura de $\mathrm{HCl} 2 \mathrm{~mol} \mathrm{~L}^{-1}, \mathrm{NH}_{4} \mathrm{Cl}$ (cloreto de amônio) $1 \mathrm{~mol} \mathrm{~L}-1, \mathrm{H}_{2} \mathrm{SO}_{4}$ (ácido sulfúrico) $2 \mathrm{~mol} \mathrm{~L}{ }^{-1}$ e $\left(\mathrm{NH}_{4}\right)_{2} \mathrm{SO}_{4}$ (sulfato de amônio) $2 \mathrm{~mol} \mathrm{~L}^{-1}$. $\mathrm{O}^{67} \mathrm{Ga}$ foi extraído com 2 porções de metil-isobutil-cetona.

NAYAK e LAHIRI ${ }^{(78)}$ propuseram um método de produção de ${ }^{67} \mathrm{Ga}$ a partir das reações ${ }^{59} \mathrm{Co}\left({ }^{11} \mathrm{~B}, 3 \mathrm{n}\right){ }^{67} \mathrm{Ge} \rightarrow{ }^{67} \mathrm{Ga}$ e ${ }^{59} \mathrm{Co}\left({ }^{12} \mathrm{C}, 3 \mathrm{n}\right){ }^{67} \mathrm{As} \rightarrow{ }^{67} \mathrm{Ge} \rightarrow{ }^{67} \mathrm{Ga}$. O alvo foi dissolvido em $\mathrm{HCl}$ concentrado e $0{ }^{67} \mathrm{Ga}$ foi extraído desta solução utilizando trioctilamina $10^{-3} \mathrm{~mol} \mathrm{~L}^{-1}$ em ciclohexano, onde $100 \%$ do ${ }^{67} \mathrm{Ga}$ foi transferido para a fase orgânica. A reversão do ${ }^{67} \mathrm{Ga}$ foi realizada com solução de DTPA 0,1 mol L ${ }^{-1}$ em $\mathrm{NaOH} 1 \mathrm{~mol} \mathrm{~L}^{-1} \mathrm{e}$ EDTA $0,1 \mathrm{~mol} \mathrm{~L}^{-1}, \mathrm{pH} 8$.

A AIEA (Agência Internacional de Energia Atômica) ${ }^{(73)}$ recomenda a reação ${ }^{68} \mathrm{Zn}(p$, $2 n)^{67} \mathrm{Ga}$ e o seguinte processamento por extração por solventes: dissolução do alvo em $\mathrm{HCl} 7,5 \mathrm{~mol} \mathrm{~L}{ }^{-1}$, extração do ${ }^{67} \mathrm{Ga}$ com 3 porções de éter diisopropílico, lavagem da fase etérea com $\mathrm{HCl} 7,5 \mathrm{~mol} \mathrm{~L}^{-1}$, nova lavagem com éter diisopropílico, extração do ${ }^{67} \mathrm{Ga}$ com volume mínimo de água estéril e adição de citrato de sódio $2,5 \%$.

Apesar de ser um método clássico de separação, a extração por solventes apresenta algumas restrições. Por ser um método manual, sua automação em celas de processamento radioativo é difícil e desta maneira o operador ficaria exposto à radiação no momento da produção. 
O uso de ácidos fortes para dissolução total do alvo e solventes orgânicos danifica os componentes da cela. Deve-se também levar em consideração se o material é tóxico ou inflamável, por exemplo, devendo-se proceder à segregação deste tipo de rejeito.

\subsubsection{Métodos utilizando a cromatografia}

A cromatografia é um método físico-químico de separação dos componentes de uma mistura, realizada através da distribuição desses componentes em duas fases que estão em contato ${ }^{(87)}$.

Uma das fases permanece estacionária, enquanto a outra se move através dela. Durante a passagem da fase móvel pela fase estacionária, os componentes da mistura são distribuídos pelas duas fases de tal forma que cada um deles é seletivamente retido pela fase estacionária, o que resulta em migrações diferenciais ${ }^{(87)}$.

Existem várias formas de realizar o processo cromatográfico. Algumas destas maneiras utilizadas para obtenção e purificação do ${ }^{67} \mathrm{Ga}$ estão descritas a seguir.

\subsubsection{Processos de separação por cromatografia de extração}

A cromatografia de extração também pode ser denominada como cromatografia de partição líquido-líquido, na qual a fase estacionária sólida retém uma fase líquida (aquosa ou orgânica), que é o agente extrator. Neste modelo, o fracionamento se faz entre os elementos contidos na fase móvel e o agente extrator fixado no suporte poroso $^{(88)}$.

A cromatografia de extração funciona basicamente da mesma forma que a extração por solvente. A separação dos elementos químicos se dá pela transferência de espécies químicas organosolúveis da fase aquosa para a fase orgânica - que na cromatografia de extração encontra-se retida em um suporte sólido ou leito poroso causada pela diferença de solubilidade dentro das duas fases imiscíveis ${ }^{\left({ }^{(8)} \text {. }\right.}$

CHAMMA $^{\left({ }^{(8)}\right)}$ realizou a separação química gálio-zinco utilizando fosfato de tri-nbutila (TBP): Benzeno (1:3) retido em uma coluna de poli-fluoro-cloro-etileno. $O$ alvo foi dissolvido em $\mathrm{HCl} 8 \mathrm{~mol} \mathrm{~L}^{-1}$, o zinco foi eluído em $\mathrm{HCl} 6 \mathrm{~mol} \mathrm{~L}^{-1}$ e o gálio foi eluído em água. A solução foi levada à secura, retomada em água, filtrada, levada à secura novamente e retomada em citrato de sódio 3,8\%, com rendimento de $99 \%$. 
WEINREICH e col. ${ }^{(90)}$ realizaram a separação química gálio-zinco utilizando o TBP como agente extrator, em coluna inerte de poli-monocloro-trifluoro-metano. ${ }^{67} \mathrm{Ga}$ foi eluído com água e o zinco permaneceu retido na coluna. Após secura da solução eluída, o ${ }^{67} \mathrm{Ga}$ foi retomado em citrato de sódio. O rendimento foi de $99 \%$.

ARZUMANOV e colab. ${ }^{(91)}$ utilizaram alvos de zinco natural para produção do ${ }^{67} \mathrm{Ga}$. $\mathrm{O}$ alvo foi dissolvido em $\mathrm{HCl} 12 \mathrm{~mol} \mathrm{~L}^{-1}$ e a solução foi percolada em uma coluna contendo uma resina inerte de policromo com uma solução adsorvida de $0,2 \mathrm{~mol} \mathrm{~L}^{-1}$ de óxido trioctilfosfato (TOPO) em tolueno. Nestas condições, o ${ }^{67} \mathrm{Ga}$ foi separado do zinco em $\mathrm{HCL}$ $0,5 \mathrm{~mol} \mathrm{~L}^{-1}$, com rendimento de $97 \%$.

A cromatografia de extração é uma técnica de fácil execução, com ampla aplicação, mas com o uso de compostos orgânicos, muitas vezes tóxicos e inflamáveis, pode apresentar os problemas já descritos na extração por solvente convencional.

\subsubsection{Processos de separação por cromatografia de adsorção}

Também denominada cromatografia líquido - sólido, o processo de separação está fundamentado nas interações entre moléculas dos solutos da fase móvel líquida e a superfície da fase estacionária sólida. Essa adsorção é devida, principalmente, a atrações dipolares (forças de Van der Waals), ou coulômbicas, incluindo a formação de ligações de hidrogênio ${ }^{(87)}$.

Há uma grande disponibilidade de adsorventes para fins cromatográficos. Entre os adsorventes mais utilizados estão sílica, alumina, silicato de magnésio, oxido de magnésio, carvão, dextrana e polímeros de estireno (comercializado com o nome Amberlite XAD) ${ }^{(87)}$

KOPECKY e MUDROVÁ ${ }^{(92)}$ utilizaram alumina como adsorvente para separação de ${ }^{67} \mathrm{Ga}$ das impurezas de zinco, cobre, ferro e germânio. $\mathrm{O}$ alvo foi dissolvido em $\mathrm{HCl} 4 \mathrm{~mol}$ $\mathrm{L}^{-1}$ e diluído a $100 \mathrm{~mL}$. Esta solução foi percolada na coluna de alumina e o ${ }^{67} \mathrm{Ga}$ foi eluído em $\mathrm{HCl} \mathrm{0,1} \mathrm{mol} \mathrm{L}^{-1}$. A recuperação foi de $65 \%$.

BRITS e STRELOW ${ }^{(93)}$ realizaram a separação química gálio-zinco utilizando o adsorvedor orgânico Amberlite XAD-7 em solução de $\mathrm{HCl} 7 \mathrm{~mol} \mathrm{~L}^{-1}$. O alvo foi dissolvido em $\mathrm{HCl}$ concentrado, o zinco foi eluído com $\mathrm{HCl} 7 \mathrm{~mol} \mathrm{~L}^{-1}$ e o gálio com $\mathrm{HCl} 0,5 \mathrm{~mol} \mathrm{~L}^{-1}$. A recuperação do ${ }^{67} \mathrm{Ga}$ foi de $92 \%$.

SANTOS ${ }^{(94)}$ também utilizou o adsorvedor XAD-7 para a obtenção do ${ }^{67} \mathrm{Ga}$. Após a 
dissolução do alvo em $\mathrm{HCl}$ concentrado e percolação na coluna, ${ }^{6}{ }^{67} \mathrm{Ga}$ foi eluído com $\mathrm{HCl}$ $3,5 \mathrm{~mol} \mathrm{~L}^{-1}$ e a recuperação foi de $93 \%$.

NAYAK e colab. ${ }^{(95)}$ desenvolveram um método diferenciado com a adsorção do ${ }^{67} \mathrm{Ga}$ em esferas de alginato de cálcio e de alginato de cálcio-ferro condicionadas em $\mathrm{HCl}$. $\mathrm{O}$ alvo de cobalto foi dissolvido em $\mathrm{HCl}$ e esta solução foi colocada em contato com as esferas por 30 minutos, sob agitação. ${ }^{\circ}{ }^{67} \mathrm{Ga}$ foi removido da superfície das esferas com $\mathrm{HCl} 0,1 \mathrm{~mol} \mathrm{~L}^{-1}$.

\subsubsection{Processos de separação por cromatografia de troca iônica}

As primeiras observações referentes à troca iônica foram feitas por WAY e THOMPSON, em 1850. Eles descobriram a capacidade do solo em remover íons de amônia e potássio de soluções que o atravessavam. A partir destas observações, vários estudos foram realizados no sentido de produzir trocadores inorgânicos mais eficientes $^{(87)}$.

Em 1917, FOLIN e BELL descreveram a utilização da troca iônica na determinação do teor de amônio na urina. Por volta de 1935, começaram a ser produzidas resinas de troca iônica orgânicas mais eficientes, constituindo uma ferramenta valiosa em processos analíticos $^{(87)}$.

O Projeto Plutônio da Comissão de Energia Atômica, nos Estados Unidos, promoveu inúmeros avanços na separação de cátions e ânions por troca iônica, despertando o interesse para a utilização deste processo cromatográfico em outras áreas ${ }^{(87)}$.

Na cromatografia por troca iônica, a fase estacionária é altamente carregada, e os solutos com cargas de sinais contrários a esta são seletivamente adsorvidos da fase móvel. Os solutos adsorvidos podem ser eluídos pelo deslocamento com outros íons, com o mesmo tipo de carga, porém com maior força de interação com a fase estacionária ${ }^{(87)}$.

Os diferentes graus de afinidade eletrostática entre o trocador e os íons da fase móvel regem este tipo de cromatografia. A separação de materiais está baseada na adsorção reversível e diferencial dos íons da fase móvel pelo grupo trocador da matriz. A diferença de afinidade entre os íons é derivada das diferenças de cargas entre fase móvel, fase estacionária e solução teste, sendo possível controlá-la utilizando fatores como pH e 
força iônica ${ }^{(87)}$.

A matriz de um trocador é constituída por um material poroso, inerte, insolúvel em água e em solventes orgânicos, apresentando ligações covalentes a grupos trocadores iônicos. Dependendo do grupo trocador, as resinas podem ser classificadas como catiônicas ou aniônicas ${ }^{(87)}$.

Os trocadores aniônicos, como o próprio nome indica, trocam ânions e apresentam, portanto, grupos iônicos positivos ligados à matriz. Os trocadores catiônicos, inversamente, trocam cátions e apresentam grupos iônicos negativos ligados à matriz ${ }^{(87)}$.

Existem trocadores inorgânicos e orgânicos, naturais e artificiais.

Como exemplo de trocadores inorgânicos naturais, pode-se citar os minerais nativos do solo ou compostos de alumino-silicatos. Os trocadores inorgânicos sintéticos são preparados a partir de óxidos de metais do grupo IV (zircônio e tório) e ácidos dos grupos V e VI (fosfato de zircônio) ${ }^{(87)}$.

A lã, o cabelo, o couro (proteínas), a celulose e o ágar (polissacarídeos) são exemplos de trocadores orgânicos naturais e apresentam propriedades trocadoras muito baixas. Os aminoácidos das proteínas podem se comportar como cátions ou ânions, dependendo do $\mathrm{pH}$. Mediante tratamentos químicos simples (sulfonação) estes aminoácidos podem se tornar trocadores catiônicos ${ }^{(87)}$.

Os trocadores orgânicos sintéticos são resinas bastante insolúveis. A primeira resina foi produzida por ADAMS e HOLMES a partir da condensação de fenóis poliídricos com formaldeído, onde o grupo responsável pela troca iônica é o grupo $\mathrm{OH}^{-}$. Todavia, tais resinas apresentavam pequena capacidade de troca, pelo fato da baixa tendência do $\mathrm{H}^{+}$ se desligar do grupo $\mathrm{OH}^{-(87)}$.

Em 1942, D'ALELIO sintetizou resinas com base no estireno cruzado com divinilbenzeno. As resinas ácidas (trocadoras catiônicas) foram preparadas por sulfonação do anel benzênico com ácido sulfúrico concentrado, ou com ácido clorosulfônico ${ }^{(87)}$.

As unidades de divinilbenzeno estabelecem uniões com outras cadeias. O grau de ligações cruzadas (porosidade) é dado pela quantidade de divinilbenzeno presente na mistura polimerizante, e porcentagens típicas são de 1, 2, 4, 8, 12 e 16\%. A porosidade do material é consequência desse grau de ligações cruzadas e selecionada conforme o propósito a que se destina, sendo comumente designada por $\mathrm{X}-1, \mathrm{X}-2$, etc, em que o número indica a porcentagem em divinilbenzeno no polímero ${ }^{(87)}$. 
As resinas básicas (trocadores aniônicos) são preparadas por clorometilação do anel benzênico, seguida por uma reação com uma amina terciária ou outro reativo ${ }^{(87)}$.

As resinas disponíveis comercialmente são baseadas em poliestireno ou poliacrilato, sendo muito resistentes, apresentando grande estabilidade química e alta capacidade de troca em toda faixa de $\mathrm{pH}^{(87)}$.

Os tipos de grupos trocadores ligados a matriz são classificados em fortes, médios e fracos ${ }^{(87)}$.

Os trocadores iônicos fortes são completamente ionizados em grandes faixas de $\mathrm{pH}$. Os trocadores fracos ou médios possuem sua dissociação influenciada pelo $\mathrm{pH}$. Os trocadores iônicos possuem algumas propriedades, entre elas a capacidade, relacionada com a quantidade de troca de íons entre a matriz e a fase móvel, e a seletividade, que aumenta em função do grau das ligações cruzadas da matriz ${ }^{(87)}$

Um dos fatores que influenciam a cromatografia por troca iônica é a escolha do trocador, que deve ser orientada em função da finalidade a que se destina. Conhecendo o material a ser separado, escolhe-se o trocador conveniente (catiônico ou aniônico), com base da acidez ou basicidade. Outro fator é a seleção da fase móvel que pode ser constituída por soluções ácidas, básicas ou tamponadas, podem ser adicionados solventes orgânicos para aumentar a seletividade de um propósito. A temperatura ideal de operação de uma coluna cromatográfica de troca iônica deve ser determinada levando em conta a estabilidade da amostra, da matriz do trocador e as alterações de $\mathrm{pH}^{\left({ }^{(87)} \text {. }\right.}$

GRUVERMAN e KRUGER ${ }^{(96)}$ desenvolveram em 1955 vários métodos para a separação de radioisótopos produzidos em cíclotron. Para a produção de ${ }^{67} \mathrm{Ga}$ utilizaram as reações nucleares ${ }^{67} \mathrm{Zn}(d, 2 n){ }^{67} \mathrm{Ga}$ e ${ }^{66} \mathrm{Zn}(d, n){ }^{67} \mathrm{Ga}$. A separação química consistiu na dissolução do alvo de zinco em volume mínimo de $\mathrm{HCl}$ concentrado e diluição desta solução para $100 \mathrm{~mL}$, adição de $20 \mathrm{mg}$ de ferro e cobre, ajuste do pH para 5,5 com solução de amônia $25 \%$ e precipitação. O precipitado foi removido por centrifugação e o sobrenadante contendo $\left[{ }^{67} \mathrm{Ga}(\mathrm{OH})_{4}\right]^{-}$foi percolado em resina Dowex-1, onde ferro e cobre foram eluídos em $\mathrm{HCl} 3 \mathrm{~mol} \mathrm{~L}^{-1}$ e $80 \%$ do ${ }^{67} \mathrm{Ga}$ foi eluído em $\mathrm{HCl} \mathrm{0,2} \mathrm{mol} \mathrm{L}^{-1}$.

SILVESTER e THAKUR ${ }^{(97)}$ irradiaram alvos de cobre com partículas $\alpha$ e a obtenção do ${ }^{67} \mathrm{Ga}$ foi realizada com dissolução do alvo em $\mathrm{HNO}_{3}$ concentrado e aquecimento da solução em $\mathrm{HCl}$. A solução foi transferida para a coluna de troca catiônica Bio-Rad AG 
50W-X8. O cobre e o ${ }^{65} \mathrm{Zn}$ foram eluídos com $\mathrm{HCl}$ concentrado e o ${ }^{67} \mathrm{Ga}$ com $10 \mathrm{~mL}$ de $\mathrm{HCl}$ $3,5 \mathrm{~mol} \mathrm{~L}^{-1}$.

HELUS e MAIER-BORST ${ }^{(72)}$ produziram ${ }^{67} \mathrm{Ga}$ a partir do bombardeamento de alvos de zinco natural com deutêrons e partículas $\alpha$. O alvo foi dissolvido em $4 \mathrm{~mL}$ de $\mathrm{HCl} 1 \mathrm{~mol}$ $\mathrm{L}^{-1}$, esta solução foi percolada em uma coluna de troca aniônica Amberlite IRA-400, préequilibrada com $\mathrm{HCl} 1 \mathrm{~mol} \mathrm{~L}^{-1}$. O zinco permaneceu retido na coluna e gálio e germânio (proveniente de reações nucleares secundárias) foram eluídos. Esta solução foi percolada em uma segunda coluna de alumina ácida, onde o germânio permaneceu retido na coluna e o gálio foi eluído em solução de $\mathrm{HCl} 1 \mathrm{~mol} \mathrm{~L}^{-1}$. A quantidade de $\mathrm{Al}^{3+}$ no produto final foi inferior a $3 \mu \mathrm{g} \mathrm{mL} L^{-1}$.

NAGAME e colab. ${ }^{(76)}$ utilizaram partículas $\alpha$ para o bombardeamento de alvos de zinco natural para produção de ${ }^{67} \mathrm{Ga}$. A separação foi realizada com a dissolução do alvo em quantidade mínima de $\mathrm{HCl}$ concentrado e a passagem desta solução em coluna de troca aniônica Dowex $1 \times 8$, com eluição do ${ }^{67} \mathrm{Ga}$ em HCl 2 mol L ${ }^{-1}$.

CHATTOPADHYAY e colab. ${ }^{(98)}$ dissolveram o alvo de cobre em $20 \mathrm{~mL} \mathrm{HNO}_{3}$ concentrado e depois reverteram a solução para cloreto com $\mathrm{HCl}$ concentrado (10 e 35 $\mathrm{mL}$ ). Posteriormente, utilizaram a resina catiônica Dowex $50 \mathrm{~W}-\mathrm{X} 8$ e o ${ }^{67} \mathrm{Ga}$ foi obtido com eluição em $35 \mathrm{~mL}$ de $\mathrm{HCl}$ 3,5 $\mathrm{mol} \mathrm{L}^{-1}$.

NAIDOO e VAN der WALT ${ }^{(77)}$ estudaram a separação do ${ }^{67}$ Ga produzido a partir da irradiação de alvos de ${ }^{\text {nat }} \mathrm{Ge}-{ }^{\text {nat }} \mathrm{Zn}$ com prótons. O alvo de ${ }^{\text {nat }} \mathrm{Zn}$ foi dissolvido em $\mathrm{HCl} 10$ $\mathrm{mol} \mathrm{L}^{-1}$, contendo $5 \mathrm{~mL}$ de cloreto de titânio(III) 0,3\%. A solução foi percolada em coluna de resina catiônica Amberchorm TM CG-71cd. A resina contendo ${ }^{67}$ Ga foi eluída com 200 $\mathrm{mL}$ de $\mathrm{HCl} 7 \mathrm{~mol} \mathrm{~L}^{-1}$ para remoção de traços dos íons zinco e titânio. $\mathrm{O}^{67} \mathrm{Ga}$ foi eluído com $30 \mathrm{~mL}$ de $\mathrm{HNO}_{3} 0,5 \mathrm{~mol} \mathrm{~L}^{-1}$, a solução foi evaporada até a secura e o resíduo dissolvido em $2 \mathrm{~mL}$ de $\mathrm{HNO}_{3} 12 \mathrm{~mol} \mathrm{~L}$.. $\mathrm{OHNO}_{3}$ foi adicionado para conversão de cloretos em nitratos menos voláteis ao aquecimento. $\mathrm{O}$ excesso de ácido foi evaporado, adicionou-se $2 \mathrm{~mL}$ de água, levou-se a secura, dissolveu-se o resíduo de ${ }^{67} \mathrm{Ga}$ em $10 \mathrm{~mL}$ de citrato de sódio $2,6 \%$.

O alvo de germânio foi dissolvido em uma solução ácido fluorídrico (HF) 40\%: peróxido de hidrogênio $30 \%(1: 1)$ e aquecido até $100^{\circ} \mathrm{C}$. Adicionaram-se $50 \mathrm{~mL}$ de $\mathrm{HCl} 10$ mol L ${ }^{-1}, 5 \mathrm{~mL}$ de cloreto de titânio (III) 0,3\% e passou-se a solução na resina Amberchorm TM CG-71cd. O germânio foi eluído em uma mistura de $\mathrm{HCl} 6 \mathrm{~mol} \mathrm{~L}^{-1}$ e HF 0,5 mol L ${ }^{-1}$ e o 
${ }^{67} \mathrm{Ga}$ com $30 \mathrm{~mL}$ de $\mathrm{HNO}_{3} 0,5 \mathrm{~mol} \mathrm{~L}^{-1}$ sendo o tratamento a partir deste ponto realizado da mesma forma como para o alvo de zinco. A pureza radionuclídica do ${ }^{67} \mathrm{Ga}$ foi de $99 \%$. Não se encontrou ${ }^{69} \mathrm{Ge}$ e ${ }^{65} \mathrm{Zn}$.

EL-AZONY e colab. ${ }^{(99)}$ demonstraram o uso da resina aniônica Dowex $21 \mathrm{~K}$ para a separação do ${ }^{67} \mathrm{Ga}$ das impurezas ${ }^{65} \mathrm{Zn}$ e ${ }^{61} \mathrm{Cu}$, resultante da irradiação com prótons de alvo de zinco natural eletrodepositado em discos de cobre. 0 experimento mostrou que o cobre e o zinco ficaram fortemente ligados a resina, ${ }^{6}{ }^{67} \mathrm{Ga}$ foi eluído em tampão citrato de sódio $0,1 \mathrm{~mol} \mathrm{~L}^{-1}$ com pureza radionuclídica de $81 \%$.

A AIEA ${ }^{(73)}$ recomenda a reação ${ }^{68} \mathrm{Zn}(p, 2 n)^{67} \mathrm{Ga}$ e o seguinte processamento para obtenção do ${ }^{67} \mathrm{Ga}$ por troca iônica: dissolução do alvo em $\mathrm{HCl}$ concentrado, percolação da solução em resina Dowex 50W-X8, 200-400 mesh, condicionada com $\mathrm{HCl} 10 \mathrm{~mol} \mathrm{~L}^{-1}$. O zinco é eluído em $\mathrm{HCl} 10$ mol. $\mathrm{L}^{-1}$ e esta solução deve ser reservada para recuperação do ${ }^{68} \mathrm{Zn}$. $\mathrm{O}^{67} \mathrm{Ga}$ é eluído com $\mathrm{HCl} 3,5 \mathrm{~mol} \mathrm{~L}^{-1}$, a solução é levada próxima à secura, são adicionadas algumas gotas de $\mathrm{H}_{2} \mathrm{O}_{2} 30 \%$, a evaporação é terminada e o ${ }^{67} \mathrm{Ga}$ é retomado em citrato de sódio 2-4\%.

HASSAN ${ }^{(100)}$ verificou o comportamento do gálio, cobre e zinco em resina aniônica Amberlyst 21b. A solução de simulação foi formada por ${ }^{72} \mathrm{Ga}$ em $\mathrm{HCl} 7 \mathrm{~mol} \mathrm{~L}^{-1} \mathrm{e}$ quantidades conhecidas de cobre e zinco, adicionadas a solução do alvo dissolvido. 0 gálio foi eluído em tampão citrato de sódio $0,1 \mathrm{~mol} \mathrm{~L}^{-1}, \mathrm{pH} 6,0$.

As resinas de troca iônica podem ser consideradas um instrumento indispensável quando se refere à separação, purificação, preparação e recuperação de radioisótopos. É uma técnica que apresenta inúmeras vantagens: rápida, de fácil execução, as resinas são estáveis e insolúveis na maioria dos solventes orgânicos e podem ser utilizadas em larga escala de $\mathrm{pH}$. Uma vez em que se trate de material radioativo, é de fácil automação em celas de processamento.

Talvez sua única desvantagem seja o fato da utilização de ácidos fortes e corrosivos, normalmente $\mathrm{HCl}$ ou $\mathrm{HNO}_{3}$, cujos vapores causam inúmeros danos à cela de processamento, como desgaste das válvulas e corrosão dos componentes. Estes fatores levaram muitas vezes à perda da produção de ${ }^{67}$ Ga no IPEN/CNEN-SP devido ao material ficar retido nas conexões.

Como já comentado, as celas de produção de radioisótopos devem atender as recomendações das BPF. Vapores gerados pelos ácidos fortes podem resultar em uma 
classificação não adequada da área para a produção de um radiofármaco injetável.

\subsubsection{Métodos utilizando a difusão térmica}

A difusão térmica aplicada na separação de radioisótopos produzidos pela irradiação de alvos sólidos desempenha um papel importante em alguns métodos de separação radioquímica como a destilação, a destilação a seco e a volatilização. É um método de separação química simples e não-destrutivo e permite a separação do radioisótopo de interesse do alvo de modo direto ${ }^{(101)}$.

O método está fundamentado na diferença entre os pontos de fusão do material utilizado como alvo e do material produzido, trabalhando próximo ao ponto de fusão do material alvo.

Um radionuclídeo pode ser considerado como uma fase dissolvida no material alvo. Quando o ponto de fusão do elemento produzido é menor do que o do material alvo, os radionuclídeos tendem a se concentrar na superfície do alvo durante o aquecimento, sendo possível sua retirada com a extração em ácidos diluídos e sem a necessidade de dissolução total do alvo ${ }^{(101)}$.

LUNDQVIST e colab. ${ }^{(102)}$ produziram ${ }^{111}$ In pela reação ${ }^{112} \mathrm{Cd}(p, 2 n){ }^{111}$ In utilizando alvos de cobre niquelados. Após a irradiação, os alvos foram aquecidos a $300{ }^{\circ} \mathrm{C} \mathrm{e}$, após o resfriamento, imersos em ácido acético concentrado. O rendimento da separação foi de 56\%. A separação química do cádmio-índio foi realizada em resina aniônica Dowex 1X8 em meio de ácido acético. $\mathrm{O}^{111}$ In foi eluído em água com rendimento superior a $98 \%$.

LION ${ }^{(103)}$ repetindo os estudos de LUNDQVIST para separação química de cádmioíndio obteve $85 \%$ de rendimento na extração em ácido acético e $100 \%$ de recuperação após a purificação em resina aniônica.

TOLMACHEV e LUNDQVIST ${ }^{(104)}$ irradiaram folhas de zinco natural com prótons para produção de ${ }^{66} \mathrm{Ga}$ e ${ }^{68} \mathrm{Ga}$. Após a irradiação, os alvos foram aquecidos a $400{ }^{\circ} \mathrm{C}$ por 30 minutos e depois agitados vigorosamente em $\mathrm{HCl} 0,05 \mathrm{~mol}^{-1} \mathrm{~L}^{-1}$. A eficiência de separação do ${ }^{66} \mathrm{Ga}$ e do ${ }^{68} \mathrm{Ga}$ do material alvo foi de $60 \%$.

Não foram encontrados na literatura estudos utilizando este método para produção e separação do ${ }^{67} \mathrm{Ga}$. 


\section{4}

\section{MATERIAIS E MÉTODOS}

\subsection{Materiais, equipamentos e infraestrutura}

Este trabalho foi realizado na Diretoria de Radiofarmácia (DIRF, IPEN/CNEN-SP) que dispõe de toda infraestrutura necessária: instalações de laboratório, materiais, reagentes e equipamentos. Na TAB. 11 são apresentados os recursos utilizados na execução deste trabalho.

TABELA 11 - Recursos utilizados na execução do trabalho

\begin{tabular}{ll}
\hline \multicolumn{1}{c}{ RECURSO } & \multicolumn{1}{c}{ MODELO/MARCA } \\
\hline Reagentes analíticos, padrões ICP & Grau PA, Merck, Alemanha \\
${ }^{67} \mathrm{GaCl}_{3}$ & Nordion, Canadá \\
\hline Resina de troca aniônica & DOWEX 1X8 (100-200 mesh), Sigma-Aldrich, EUA \\
\hline Resina de troca catiônica & DOWEX 50WX8 (100-200 mesh), Sigma-Aldrich, \\
& EUA \\
\hline Placas de cobre & Alumb, Brasil \\
\hline Placa de cobre niquelada & Metalúrgica São João, Brasil \\
\hline Papel cromatográfico & Whatman 3MM, Whatman International Ltd, \\
& Reino Unido \\
Purificador de água & Elix 10, Millipore, E.U.A. \\
Acelerador cíclotron & Cyclone 30, IBA, Bélgica \\
\hline Balança analítica & AUW 220, Shimadzu, Japão \\
\hline Fonte de tensão estabilizada & TC-15-003XA1A, Tectrol, Brasil \\
\hline Forno mufla & FC 1.25, EDG, Brasil \\
\hline
\end{tabular}




\begin{tabular}{|c|c|}
\hline Estufa para secagem & NT 513M, Nova Tecnisa, Brasil \\
\hline Espectrofotômetro por emissão de plasma & ICP-OES, Vista MPX, Varian Inc., Austrália \\
\hline Contador gama tipo poço - cristal de Nal & $\begin{array}{l}\text { Cobra II, Packard Bioscience Company, Reino } \\
\text { Unido }\end{array}$ \\
\hline Contador linear & AR-2000, Bioscan, EUA \\
\hline Calibrador de doses & CRC-15C, Capintec Inc., EUA \\
\hline Detector de germânio Hiper-Puro & GX1518, Canberra Inc., EUA \\
\hline Micrômetro & MITUTOYO Micrometer BMD-25, Japão \\
\hline Microscópio eletrônico de varredura & PHILIPS, Modelo XL30, Holanda \\
\hline
\end{tabular}

\subsection{Métodos}

\subsubsection{Fluxograma dos experimentos}

A FIG. 8 representa o esquema das etapas dos experimentos realizados neste trabalho.

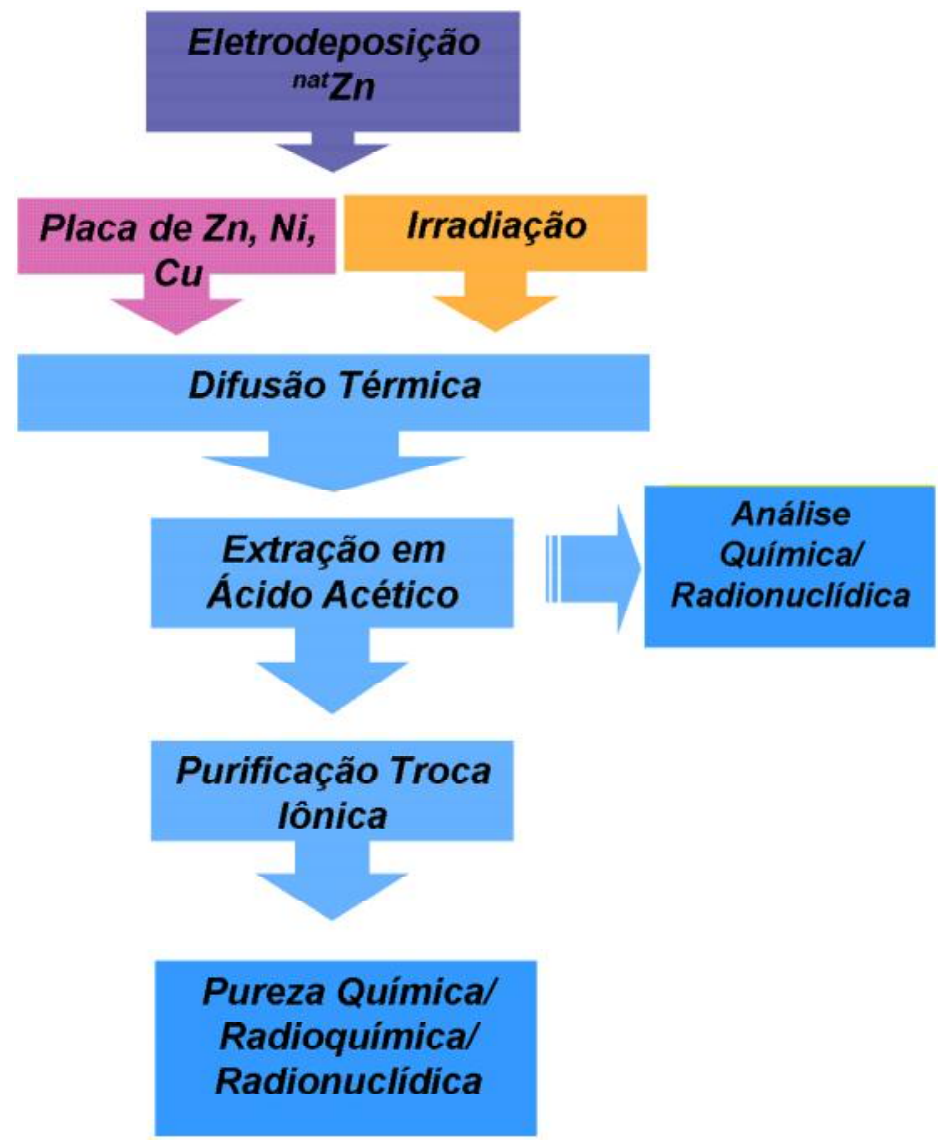

FIGURA 8. Fluxograma dos experimentos 
O ${ }^{67} \mathrm{Ga}$ foi obtido pela reação nuclear ${ }^{67} \mathrm{Zn}(p, n){ }^{67} \mathrm{Ga}$. Para isto, realizou-se a eletrodeposição do zinco natural em placas de cobre niquelado como substrato.

A base de separação do ${ }^{67} \mathrm{Ga}$ do material alvo foi pelo processo de difusão térmica (aquecimento do alvo) aliada à extração em ácido acético concentrado (HAc), de concentração $17,5 \mathrm{~mol} \mathrm{~L}^{-1}$.

Para a escolha das condições ideais de aquecimento e extração em HAc dos alvos irradiados, realizaram-se ensaios variando a temperatura, o tempo de aquecimento e o tempo de extração em HAc em placas contendo o depósito de zinco não irradiado, em placas de cobre niquelado e em placas de cobre.

Um alvo de zinco irradiado representa um sistema binário, contendo dois componentes com diferentes pontos de fusão. $\mathrm{O}$ ponto de fusão do zinco, $420{ }^{\circ} \mathrm{C}$ é mais alto que o do gálio, $29,7^{\circ} \mathrm{C}$. Quando o alvo é aquecido acima de $30^{\circ} \mathrm{C}$, os átomos de gálio criam uma nova "fase" na superfície do zinco. O gálio na superfície do alvo pode ser retirado com ácidos fracos ou soluções diluídas ${ }^{(104)}$

A solução de HAc contendo ${ }^{67} \mathrm{Ga}$ apresenta impurezas químicas provenientes do material alvo e dos reagentes utilizados. Dois métodos de troca iônica utilizando uma resina aniônica e uma resina catiônica foram estudados para obtê-lo com pureza química, radioquímica e radionuclídica adequada.

\subsubsection{Preparo de alvos por eletrodeposição}

Os alvos de zinco natural utilizados para estudos de difusão térmica e para as irradiações no Cyclone-30 foram preparados por eletrodeposição em placas de cobre niquelado.

O ânodo consistiu de uma malha retangular de platina acoplado à cuba de eletrodeposição. O zinco foi eletrodepositado sobre o cátodo, que consistiu da própria placa de cobre niquelado.

Antes da eletrodeposição, a superfície da placa foi limpa com detergente, polida com alumina $\left(\mathrm{Al}_{2} \mathrm{O}_{3}\right)$, limpa com tetracloreto de carbono, lavada com água purificada, seca em estufa e pesada. A placa não apresentou riscos profundos e se encaixou perfeitamente na cuba de eletrodeposição.

A placa de cobre niquelada foi centralizada no interior de uma placa de ferro. A cuba acrílica de eletrodeposição foi posicionada e parafusada por cima. 
As reações eletroquímicas envolvidas na eletrodeposição do Zn são ${ }^{(7)}$ :

(1) Geração de Hidrogênio $\rightarrow 2 \mathrm{H}^{+}(\mathrm{aq})+2 \mathrm{e}^{-} \rightarrow \mathrm{H}_{2}(\mathrm{~g}) \uparrow$

(2) Redução do oxigênio $\rightarrow \mathrm{O}_{2}(\mathrm{~g})+4 \mathrm{H}^{+}(\mathrm{aq})+4 \mathrm{e}^{-} \rightarrow 2 \mathrm{H}_{2} \mathrm{O}$

(3) Deposição do metal $\rightarrow \mathrm{Zn}^{+2}+2 \mathrm{e}^{-} \Leftrightarrow \mathrm{Zn}^{0} \downarrow$

Utilizaram-se placas com 2 geometrias diferentes. As irradiações no Cyclone-30 foram realizadas com placas de dimensões de 7 x 2,7 cm devido à disponibilidade deste tipo de porta-alvo. Para os estudos de difusão utilizaram-se placas de dimensões $12 \times 3$ $\mathrm{cm}$.

Para uma melhor descrição dos experimentos cada tipo de placa foi denominado de Placa para Difusão e Placa para Irradiação.

A TAB. 12 mostra as características de cada tipo de placa e as condições de eletrodeposição utilizadas para cada uma.

TABELA 12 - Características das placas utilizadas e condições de eletrodeposição

\begin{tabular}{|c|c|c|}
\hline & Placas para Difusão * & Placas para Irradiação \\
\hline Finalidade & Estudo de Difusão Térmica & Irradiações \\
\hline Dimensões da placa (cm) & $12 \times 3$ & $7 \times 2,7$ \\
\hline Dimensões da cuba $(\mathrm{cm})$ & $16 \times 11$ & $12 \times 6,5$ \\
\hline Área do ânodo de platina $\left(\mathrm{cm}^{2}\right)$ & 11,54 & 7,68 \\
\hline \multirow[t]{3}{*}{ Eletrólito } & $50 \mathrm{~mL}$ de $\mathrm{ZnSO}_{4} \cdot 7 \mathrm{H}_{2} \mathrm{O} 0,45$ & $35 \mathrm{~mL}$ de $\mathrm{ZnSO}_{4} .7 \mathrm{H}_{2} \mathrm{O} 0,45$ \\
\hline & $\mathrm{mol} \mathrm{L}^{-1}+100 \mathrm{~mL}$ de $\mathrm{H}_{2} \mathrm{SO}_{4}$ & $\mathrm{~mol} \mathrm{~L}^{-1}+80 \mathrm{~mL}$ de $\mathrm{H}_{2} \mathrm{SO}_{4}$ \\
\hline & $0,1 \mathrm{~mol} \cdot \mathrm{L}^{-1}$ & $0,1 \mathrm{~mol} \cdot \mathrm{L}^{-1}$ \\
\hline Densidade de corrente (mA) & 300 & 300 \\
\hline Tempo de processo (horas) & $2: 45$ & 4:00 e 2:00 \\
\hline Agitação da solução & $\mathrm{N}_{2}$ & Sem agitação \\
\hline
\end{tabular}

* Condições utilizadas na produção rotineira do IPEN ${ }^{(19)}$.

A FIG. 9 mostra de modo esquemático os componentes da cuba de eletrodeposição e a FIG. 10 ilustra a cuba onde se realizaram as eletrodeposições de zinco. 


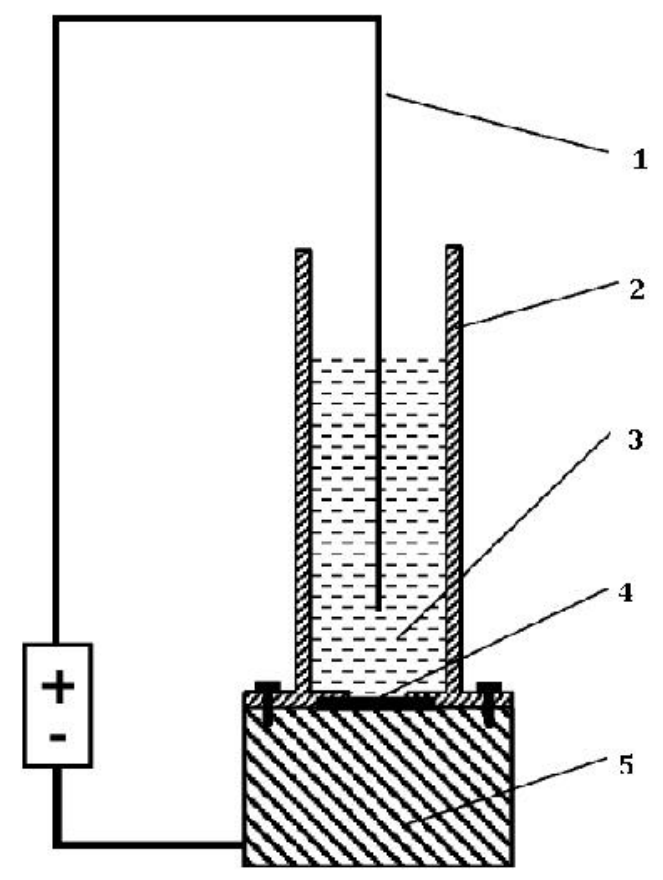

FIGURA 9. Cuba de eletrodeposição e seus componentes: (1) ânodo de platina; (2) cuba de acrílico; (3) eletrólito; (4) placa de cobre niquelado; (5) cátodo de ferro

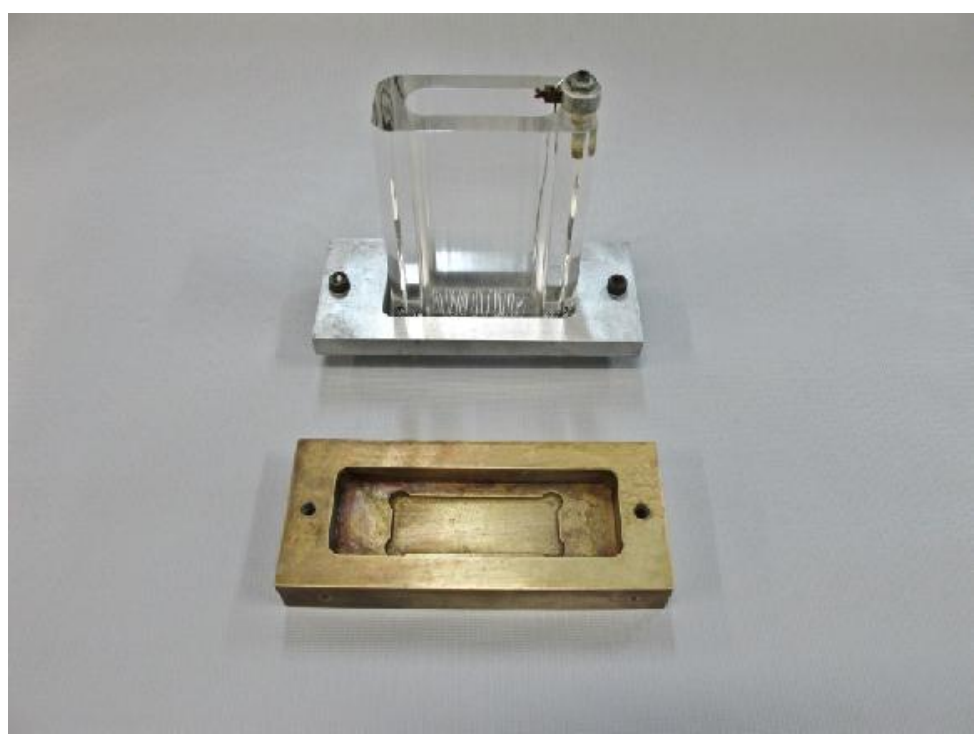

FIGURA 10. Cuba de eletrodeposição de ${ }^{\text {nat }} \mathrm{Zn}$ para preparo de Alvos para irradiação 
A avaliação do depósito obtido consistiu em:

1 - Análise visual, caracterizando a aparência e a aderência dos depósitos,

2 - Pesagem da placa para verificação da massa obtida,

3 - Espessura e homogeneidade do depósito, verificada com o auxílio de um micrometro, a partir de 6 medições distribuídas sobre a área eletrodepositada. Um desvio padrão de $\pm 5 \%$ na espessura média é aceitável ${ }^{(8)}$.

4 - Caracterização morfológica dos depósitos, realizada por Microscopia Eletrônica de Varredura (MEV), obtendo-se micrografia com ampliações de 25 e 1000 vezes para análise superficial.

\subsubsection{Estudos de difusão térmica com placas não irradiadas}

O comportamento dos metais perante o aumento de temperatura (difusão térmica) pode ser verificado observando sua condutividade térmica e seu comportamento de dissolução em ácidos pode ser verificado observando sua eletropositividade ${ }^{(105)}$.

A eletropositividade, ou caráter metálico, é a capacidade de um átomo perder elétrons, originando cátions. Os metais apresentam elevadas eletropositividades, com grande capacidade de perder elétrons. Para os metais em estudo neste trabalho, a capacidade de formação de cátions, ou sua capacidade de dissolução em ácidos, a eletropositividade ocorre nesta ordem: $\mathbf{G a}>\mathbf{Z n}>\mathbf{N i}>\mathbf{C u}^{(105)}$.

As propriedades de um sólido dependem da geometria do retículo cristalino, da natureza das unidades (átomos, íons, moléculas) e das forças que mantêm unidas estas unidades. Assim, os sólidos podem ser classificados em quatro tipos: iônico, molecular, covalente e metálico ${ }^{(105)}$.

Num sólido metálico as unidades que ocupam os pontos reticulares são íons positivos. Por exemplo, no metal sódio os íons $\mathrm{Na}^{+}$ocupam os pontos de um retículo cúbico de corpo centrado. Cada $\mathrm{Na}^{+}$pode ser considerado como sendo o resultado da perda de um elétron por átomo de sódio, e os elétrons de todos os átomos de sódio formam uma nuvem gigante de elétrons que se espalha por todo o retículo ${ }^{(105)}$.

Alguns metais são duros porque a ligação metálica é complementada por ligações covalentes entre cátions adjacentes no retículo. Estas ligações covalentes tendem a manter estes íons presos no lugar, prevenindo assim a deformação do retículo. O ponto 
de fusão de metais varia consideravelmente devido às diferenças no grau da ligação covalente complementar. Por exemplo, o ponto de fusão do sódio e do tungstênio são respectivamente 98 e $3410^{\circ} \mathrm{C}^{(105)}$.

Os elétrons livres num metal são responsáveis por suas características de condutividade elétrica e térmica.

Quando calor é adicionado a uma extremidade de um pedaço de metal, o resultado é um aumento na energia cinética dos íons e dos elétrons, que se movem mais rapidamente através do metal. A capacidade dos elétrons livres de transmitir energia rapidamente de uma extremidade do metal à outra é responsável pela alta condutividade térmica mostrada pela maioria dos metais ${ }^{(105)}$.

As condutividades térmicas do cobre, zinco, níquel e gálio são, respectivamente, $401,116,90,75$ e $40,6 \mathrm{~W} \mathrm{~m}^{-1}{ }^{\circ} \mathrm{K}^{-1}$. Desta maneira, para os metais em estudo o efeito da temperatura, com fornecimento de calor e aumento da energia cinética ocorre nesta ordem: $\mathbf{C u}>\mathbf{Z n}>\mathbf{N i}>\mathbf{G a}^{(70)}$.

Os ensaios de difusão térmica foram realizados em três tipos de placas não irradiadas:

1 - Placas contendo zinco natural eletrodepositado em cobre niquelado, com legenda $[\mathrm{Zn} / \mathrm{Ni} / \mathrm{Cu}]$ - para verificar o comportamento do zinco;

2 - Placas de cobre niquelado, com legenda $[\mathrm{Ni} / \mathrm{Cu}]$ - para verificar o comportamento do níquel, utilizado como subtrato para deposição do zinco;

3 - Placas de cobre, com legenda [Cu] - para verificar o comportamento do metal e sua utilização como subtrato para a deposição do zinco como descrito na literatura.

Estes ensaios tiveram o objetivo de verificar a liberação/dissolução dos metais e seus íons frente ao aquecimento e à extração com HAc e para escolha das melhores condições para o processamento dos alvos irradiados.

As placas de níquel e cobre foram limpas como as de zinco e pesadas antes da sua utilização.

Os parâmetros avaliados foram:

1 - Temperatura de aquecimento $-25^{\circ} \mathrm{C}, 100^{\circ} \mathrm{C}$ e $200^{\circ} \mathrm{C}$;

2 - Tempo de aquecimento - 30 minutos, 1 hora e 2 horas

3 - Tempo de extração em HAc - 30 minutos, 1 hora e 2 horas. 
A extração foi realizada após o resfriamento das placas, em dissolvedor de vidro, contendo $20 \mathrm{~mL}$ de HAc, como mostrado na FIG. 11.

Após o período de extração, as placas foram secas em estufa e pesadas novamente. Todos os ensaios foram realizados em triplicata.

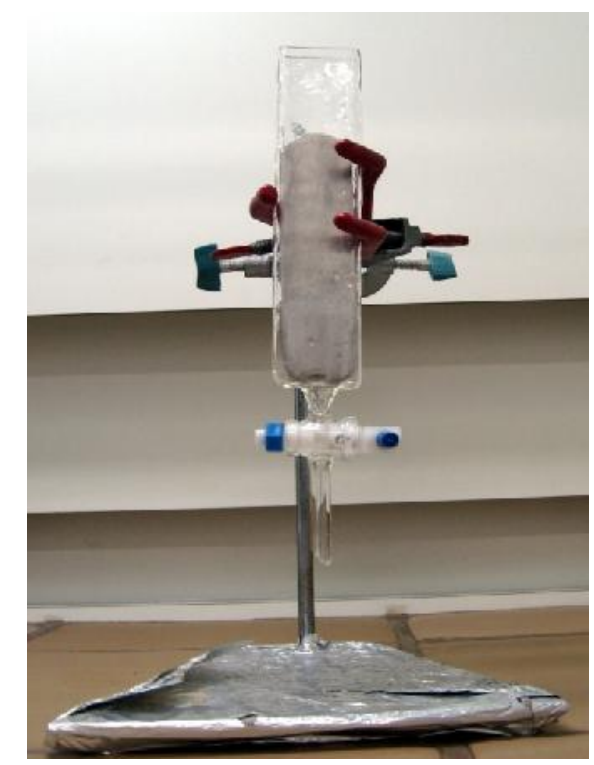

FIGURA 11. Aparato de vidro para extração do ${ }^{67} \mathrm{Ga}$ em HAc

\subsubsection{Análise química das soluções obtidas nos ensaios com placas não irradiadas}

Todas as amostras obtidas nas extrações com HAc nos ensaios descritos no item 4.2.3 tiveram cobre, níquel e zinco quantificados por ICP-OES.

A Espectrometria de Emissão Óptica com Plasma Acoplado Indutivamente (ICPOES) é uma técnica analítica eficiente e moderna para a determinação direta de metais em baixas concentrações e com alta sensibilidade. A maior vantagem do plasma acoplado é sua alta temperatura (5000-10000 K) capaz de atomizar a maioria dos elementos químicos, tornando possível uma análise multielementar de metais, em curto espaço de tempo ${ }^{(6)}$.

Utilizou-se água purificada para diluição das amostras, preparações do branco e dos padrões. As curvas de calibração foram construídas no intervalo de 2-10 $\mu \mathrm{g} \mathrm{mL}^{-1}$ a partir da diluição de padrões de $100 \mu \mathrm{gL}^{-1}$ de cada íon. 
As amostras foram diluídas na razão 1:100 e as quantidades de $\mathrm{Cu}$, Ni e $\mathrm{Zn}$ foram determinadas a 327,395; 230,299 e 213,857 nm, respectivamente. Os comprimentos de onda escolhidos são os mais sensíveis e que apresentam menores interferências espectrais para cada metal.

\subsubsection{Irradiações no Cyclone-30}

Os alvos contendo zinco eletrodepositado, como descrito no item 4.2.2, foram irradiados no cíclotron Cyclone-30.

A posição de irradiação foi inclinada, com ângulo de $6^{\circ}$ em relação ao feixe externo de prótons. Este ângulo de inclinação é para auxiliar no suporte do calor gerado na irradiação. A energia dos prótons foi de $26 \mathrm{MeV}$, com corrente integrada de $10 \mu \mathrm{A}$.h.

Na FIG. 12 tem-se a estação de irradiação para alvos sólidos do Cyclone-30.

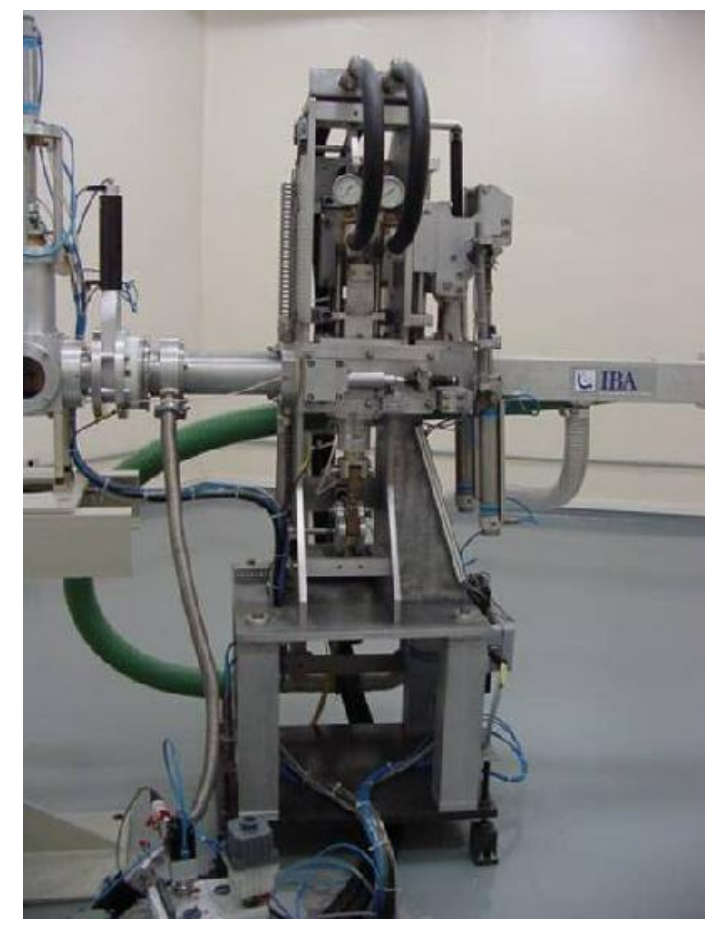

FIGURA 12. Estação de irradiação para alvos sólidos do Cyclone-30

\subsubsection{Ensaios de difusão térmica com placas irradiadas}

Os alvos irradiados foram processados 3 dias após o fim da irradiação (EOB - End Of Bombardment) para decaimento das impurezas radionuclídicas $\left({ }^{66} \mathrm{Ga}\right)$.

As placas foram primeiramente pesadas para verificar se houve perda de massa e a 
atividade foi cuidadosamente medida em calibrador de doses.

Os parâmetros avaliados foram:

1 - Temperatura de aquecimento $-100{ }^{\circ} \mathrm{C}, 200^{\circ} \mathrm{C}$ e $300^{\circ} \mathrm{C}$;

2 - Tempo de aquecimento - 1 hora e 2 horas

3 - Tempo de extração em HAc -1 hora.

Após o resfriamento das placas, a extração do ${ }^{67} \mathrm{Ga}$ foi realizada utilizando $15 \mathrm{~mL}$ de HAc, em dissolvedor de vidro (FIG. 11), por 1 hora.

Após a extração, a solução foi coletada e a atividade foi medida em calibrador de doses. Retiraram-se alíquotas para determinação da pureza química antes da fase de separação química.

Para avaliação do rendimento da extração de ${ }^{67} \mathrm{Ga}$ em HAc, após o processo de extração, o alvo de $\mathrm{Zn}$ foi dissolvido em $15 \mathrm{~mL}$ de $\mathrm{HCl}$ concentrado.

Alíquotas de $100 \mu \mathrm{L}$ e com até $370 \mathrm{kBq}(10 \mu \mathrm{Ci})$ das soluções provenientes da extração em HAc e da dissolução em HCl foram medidas em detector de Germânio Hiperpuro. Verificou-se o pico com energia de $184 \mathrm{keV}$ para quantificação do ${ }^{67} \mathrm{Ga}$ em cada tipo de amostra. O rendimento de extração em HAc foi calculado conforme a fórmula abaixo:

(\%) Extração ${ }^{67} \mathrm{Ga}_{\mathrm{HAc}}=$ Atividade ${ }_{\mathrm{HAc}} /$ Atividade $_{\mathrm{HAc}}+$ Atividade $_{\mathrm{HCl}} \times 100$

\subsubsection{Separação química em resina aniônica Dowex $1 \times 8$}

Esta fase tem por objetivo purificar o ${ }^{67} \mathrm{Ga}$ obtido por difusão térmica e obtê-lo na forma de ${ }^{67} \mathrm{GaCl}_{3}$.

Utilizou-se a resina Dowex $1 \times 8,100-200$ mesh, aniônica forte, forma $\mathrm{Cl}^{-}$. A resina foi preparada e condicionada em meio de $\mathrm{HCl} 0,1$ mol. $\mathrm{L}^{-1}$ e $\mathrm{NaOH} 0,1$ mol. $\mathrm{L}^{-1}$, permanecendo armazenada em $\mathrm{HCl} \mathrm{0,1} \mathrm{mol} \mathrm{L}^{-1}$.

A coluna cromatográfica foi preparada nas dimensões de $6 \times 2 \mathrm{~cm}$. Na parte inferior da coluna foi colocada uma camada de lã de vidro para evitar a perda da resina através do fluxo da solução. Colocou-se também uma camada na parte superior para evitar o espalhamento das partículas da resina pelas paredes da coluna. A coluna foi condicionada com $50 \mathrm{~mL}$ de HAc. O ácido acético utilizado sempre foi concentrado. 
Van den Winkel e colab. ${ }^{(106)}$ estudaram o comportamento de 65 elementos na resina aniônica Dowex 1X8 em meio de HAc.

As FIG. 13 e FIG. 14 apresentam as curvas de adsorção em ácido acético para o níquel, cobre, zinco e gálio, respectivamente.
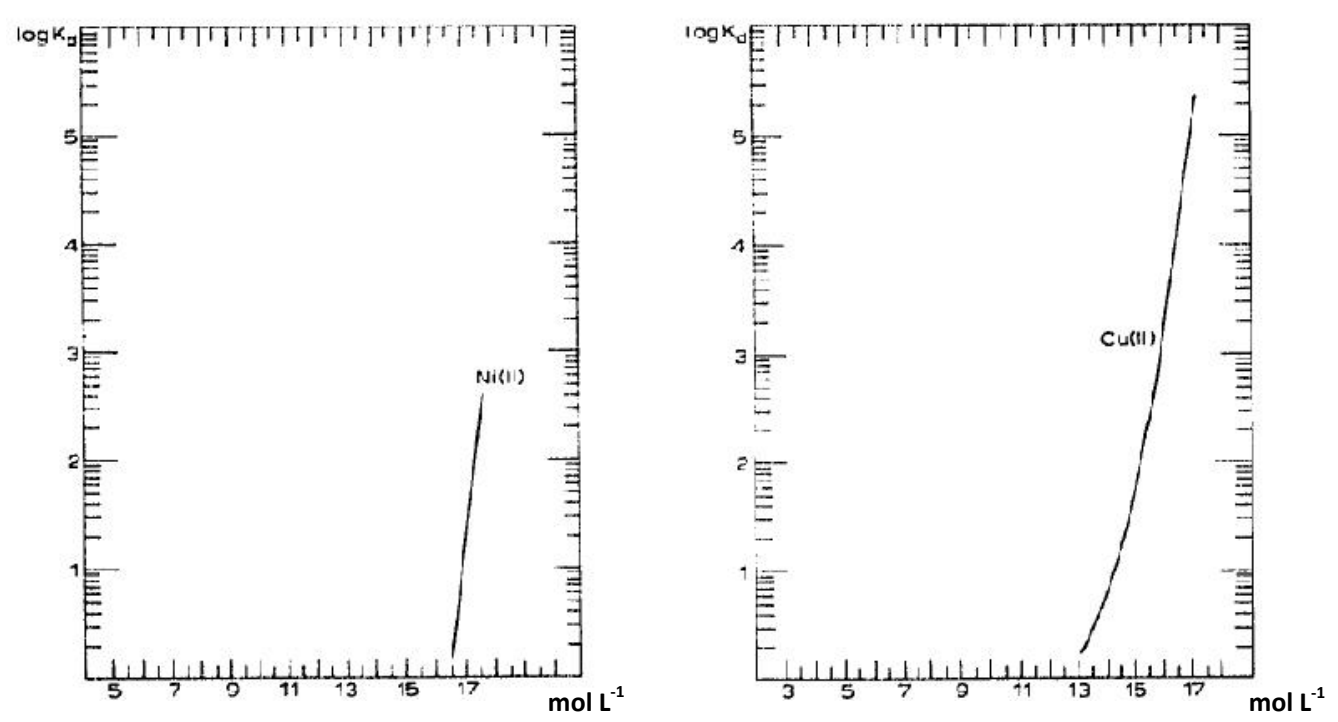

FIGURA 13 - Curva de adsorção para o níquel e o cobre em ácido acético (106)
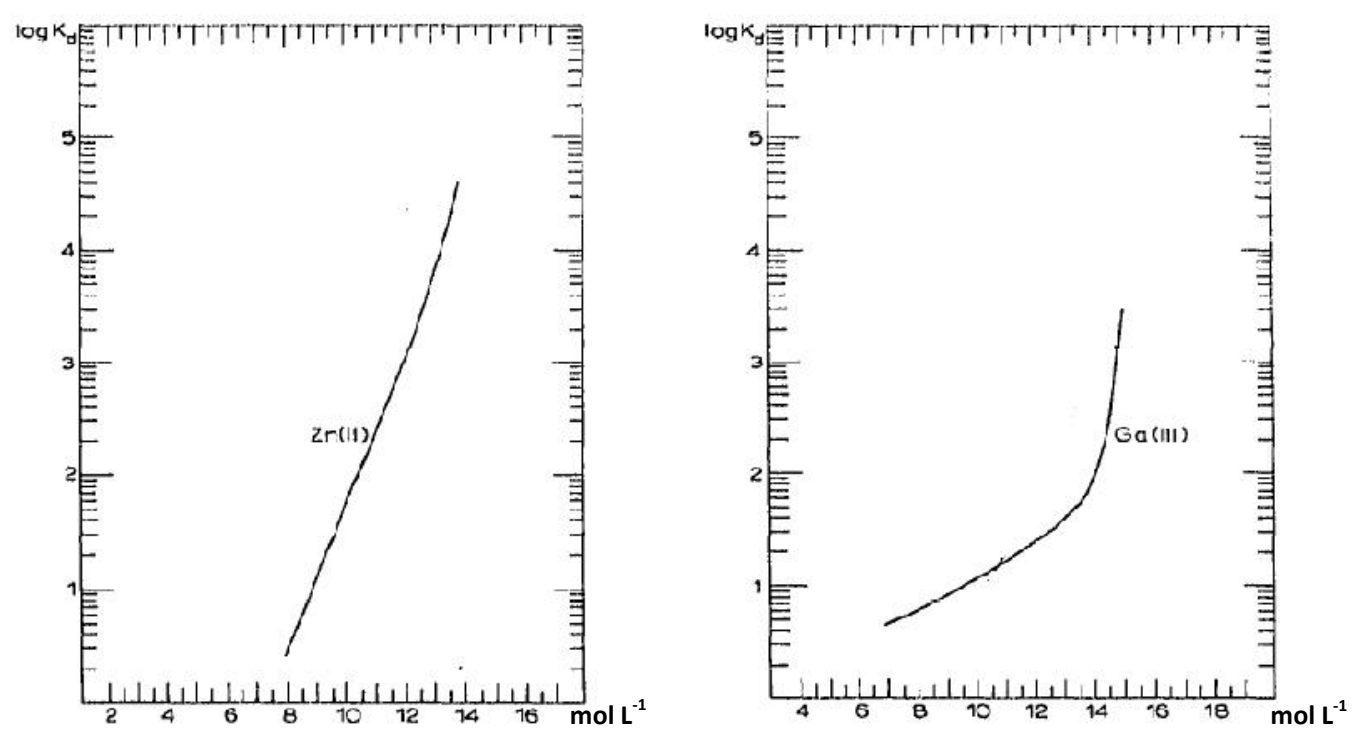

FIGURA 14 - Curva de adsorção para o zinco e o gálio em ácido acético ${ }^{(106)}$ 
$\mathrm{O} \mathrm{Ni}{ }^{+2}$ é adsorvido na resina em concentrações superiores a $16,5 \mathrm{~mol} \mathrm{~L}^{-1}$ de HAc. A adsorção de $\mathrm{Cu}^{+2}$ ocorre em concentrações superiores a $13 \mathrm{~mol} \mathrm{~L}^{-1}$, semelhante a de outros elementos divalentes tais como o $\mathrm{Co}^{+2}$ e o Ni ${ }^{+2}$. A adsorção de $\mathrm{Zn}^{+2}$ aumenta com a molaridade do HAc entre 8 e $16 \mathrm{~mol} \mathrm{~L}^{-1}$. O comportamento do $\mathrm{Ga}^{+3}$ e do $\ln ^{+3}$ são similares: ambos são adsorvidos em concentrações de HAc superiores a $8 \mathrm{~mol} \mathrm{~L}^{-1}$ (106).

\subsubsection{Comportamento de $\mathrm{Cu}$, $\mathrm{Ni}$ e $\mathrm{Zn}$}

Preparou-se uma solução carga a partir da mistura de $\mathrm{Cu}$, Ni e Zn provenientes dos experimentos de difusão térmica com alvos não irradiados (item 4.2.3), com 2 horas de aquecimento a $200^{\circ} \mathrm{C}$ e 2 horas de extração em HAc.

Utilizou-se uma alíquota de $5 \mathrm{~mL}$ da amostra de cada placa e $5 \mathrm{~mL}$ de HAc para um volume final de $20 \mathrm{~mL}$.

A carga foi percolada na resina, com coleta de frações a cada $5 \mathrm{~mL}$. Em seguida, a coluna foi lavada com $50 \mathrm{~mL}$ de ácido acético concentrado, com coleta de frações a cada

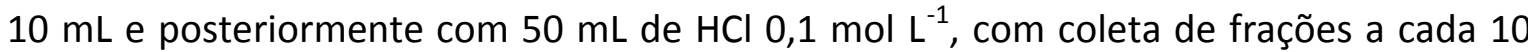
$\mathrm{mL}$.

As amostras coletadas foram diluídas na razão 1:100 e as quantidades de $\mathrm{Cu}, \mathrm{Ni}$ e Zn foram determinadas por ICP-OES. Estes ensaios foram realizados em triplicata.

\subsubsection{Comportamento do ${ }^{67} \mathrm{Ga}$}

Para avaliação do comportamento do ${ }^{67} \mathrm{Ga}$, utilizou-se uma solução preparada a partir de $37 \mathrm{MBq} / 1 \mathrm{~mL}$ (1 mCi / mL) de ${ }^{67} \mathrm{GaCl}_{3}$ (NORDION, Canadá) com adição de $19 \mathrm{~mL}$ de HAc, para um volume final de $20 \mathrm{~mL}$.

A carga foi percolada na resina e a lavagem da coluna foi realizada como descrito no item 4.2.7.1. As amostras coletadas foram medidas em calibrador de doses para verificar a eluição do ${ }^{67} \mathrm{Ga}$.

A primeira fração de $\mathrm{HCl} 0,1 \mathrm{~mol} \mathrm{~L}^{-1}$ foi levada à secura, para eliminação do ácido acético e retomada em novo $\mathrm{HCl} 0,1 \mathrm{~mol} \mathrm{~L}^{-1}$. Realizou-se a determinação da pureza radioquímica para verificação da forma ${ }^{67} \mathrm{GaCl}_{3}$.

Estes ensaios foram realizados em triplicata. 


\subsubsection{Separação química de ${ }^{67} \mathrm{Ga} / \mathrm{Zn}$ nas placas irradiadas}

Após o período de difusão e de extração do ${ }^{67} \mathrm{Ga}$ em HAc das placas irradiadas, como descrito no item 4.2.6, procedeu-se a purificação utilizando a resina de troca aniônica Dowex 1X8, 100-200 mesh, preparada e condicionada como no item 4.2.7.

Nos 3 ensaios iniciais, as cargas de 14,5 mL foram percoladas na resina, com coleta de frações a cada $5 \mathrm{~mL}$. Em seguida, a coluna foi lavada com $50 \mathrm{~mL}$ de HAc e em seguida com $50 \mathrm{~mL}$ de $\mathrm{HCl} \mathrm{0,1} \mathrm{mol} \mathrm{L}{ }^{-1}$, com coleta de frações a cada $10 \mathrm{~mL}$.

Nos ensaios seguintes, para uma melhora na eluição do zinco, após a lavagem com $50 \mathrm{~mL}$ de HAc, lavou-se a coluna com $20 \mathrm{~mL}$ de $\mathrm{HCl} 6 \mathrm{~mol} \mathrm{~L}^{-1}$, com coleta de frações a cada $5 \mathrm{~mL}$. Em seguida, lavou-se a coluna com $50 \mathrm{~mL}$ de $\mathrm{HCl} \mathrm{0,1} \mathrm{mol} \mathrm{L}^{-1}$, com coleta de frações a cada $10 \mathrm{~mL}$.

A primeira fração de $\mathrm{HCl} 0,1 \mathrm{~mol} \mathrm{~L}^{-1}$ foi levada à secura, para eliminação do ácido acético e retomada em novo $\mathrm{HCl} 0,1 \mathrm{~mol}^{-1} \mathrm{~L}^{-1}$. As amostras coletadas foram medidas em calibrador de doses para verificar a eluição do ${ }^{67} \mathrm{Ga}$.

Retiraram-se alíquotas para determinação da pureza química, radioquímica e radionuclídica.

\subsubsection{Separação química de ${ }^{67} \mathrm{Ga} / \mathrm{Zn}$ em resina catiônica Dowex 50WX8}

Estudou-se também a separação ${ }^{67} \mathrm{Ga} / \mathrm{Zn}$ em resina Dowex 50WX8, 100-200 mesh, catiônica forte, forma $\mathrm{H}^{+}$.

De acordo com ABRÃO ${ }^{(107)}$ o gálio pode ser separado de níquel, cobre e zinco em resina catiônica do tipo SBS (estireno-butadieno-estireno) em meio de $\mathrm{NH}_{4} \mathrm{OH}$. Os aminocomplexos de cobre, níquel e zinco possuem carga positiva e são retidos pela resina catiônica. $\mathrm{O}$ gálio, com caráter anfótero, em pH superior a 7,4 está na forma do íon galato $\left({ }^{67} \mathrm{Ga}(\mathrm{OH})_{4}{ }^{-}\right)$, passando através da coluna ${ }^{(23,69)}$.

Quando um íon metálico se combina com um grupo doador de um par de elétrons, o composto resultante é chamado de complexo. Os íons ou moléculas ligadas ao átomo metálico por coordenação são denominados de ligantes e devem possuir pares de elétrons não compartilhados, para que estabeleçam as ligações. Pode-se admitir que o número de coordenação corresponde ao número de orbitais híbridos e disponíveis para ligações que o átomo central apresenta ${ }^{(6)}$. 
As ligações entre os ligantes e o átomo central, nos íons complexos, são predominantemente coordenadas, ao invés de covalentes, uma vez que os cátions metálicos já são deficientes em elétrons, isto é, têm caráter eletropositivo. Por esta razão, a maioria dos cátions metálicos tende a atrair moléculas polares e íons carregados negativamente, que contenham pares isolados de elétrons. A atração é tão forte que, a não ser os cátions dos elementos dos grupos IA e IIA da classificação periódica, todos os demais se apresentam em solução, na forma de cátions complexos. Isto significa que, em lugar de cátions comuns, aparecem íons complexos formados do cátion metálico e de moléculas do solvente. Servem de exemplo os cátions $\left[\mathrm{Al}\left(\mathrm{H}_{2} \mathrm{O}\right)_{6}\right]^{3+},\left[\mathrm{Fe}\left(\mathrm{H}_{2} \mathrm{O}\right)_{6}\right]^{2+}$, no caso do solvente ser a água. Com outros solventes, como amônia líquida, ácido acético glacial, éter, acetona, um cátion sofreria uma solvatação, de maneira similar ao que ocorre com a água (hidratação) ${ }^{(6)}$.

A formação de complexos na análise qualitativa inorgânica é uma ferramenta muito utilizada para a separação ou identificação de íons.

Os amino-complexos são formados pela adição de um excesso de amônia a certos íons metálicos como o cobre, níquel e zinco: $\mathrm{Cu}\left(\mathrm{NH}_{3}\right)_{4}{ }^{+2}, \mathrm{Ni}\left(\mathrm{NH}_{3}\right)_{6}{ }^{+2}$ e $\mathrm{Zn}\left(\mathrm{NH}_{3}\right)_{4}{ }^{+2(6)}$.

A resina catiônica Dowex 50WX8 possui matriz em poliestireno, então se espera o mesmo comportamento dos íons gálio, zinco, níquel e cobre.

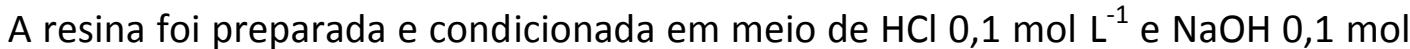
$\mathrm{L}^{-1}$, permanecendo armazenada em $\mathrm{NH}_{4} \mathrm{OH} \mathrm{0,5} \mathrm{mol} \mathrm{L}^{-1}$.

A coluna cromatográfica foi preparada nas dimensões de $6 \times 2 \mathrm{~cm}$, com uma camada de lã de vidro na parte inferior e superior da coluna.

Antes do início do processo de separação a coluna foi condicionada com $20 \mathrm{~mL}$ de $\mathrm{NH}_{4} \mathrm{OH} 0,5 \mathrm{~mol} \mathrm{~L}^{-1}$.

Após o período de difusão e de extração em ácido acético concentrado das placas irradiadas, como descrito no item 4.2 .6 , a solução contendo ${ }^{67} \mathrm{Ga}$ foi evaporada até a secura e retomada em $3 \mathrm{~mL}$ de $\mathrm{NH}_{4} \mathrm{OH} 0,5 \mathrm{~mol} \mathrm{~L}^{-1}$.

A carga foi percolada pela resina e recolhida. Em seguida, a coluna foi lavada com $30 \mathrm{~mL}$ de $\mathrm{NH}_{4} \mathrm{OH} 0,5 \mathrm{~mol} \mathrm{~L}^{-1}$, com coleta de frações a cada $10 \mathrm{~mL}$ e posteriormente com $10 \mathrm{~mL}$ de $\mathrm{HCl} 0,1 \mathrm{~mol} \mathrm{~L}^{-1}$.

Retiraram-se alíquotas para determinação da pureza química e radionuclídica. 
A carga coletada e os primeiros $20 \mathrm{~mL}$ recolhidos da lavagem da coluna foram misturadas e levadas a uma nova secura. Ao resíduo adicionou-se $2 \mathrm{~mL} \mathrm{de} \mathrm{HCl} 0,1 \mathrm{~mol} \mathrm{~L}^{-1}$. Retiraram-se alíquotas para determinação da pureza química, radionuclídica e radioquímica.

\subsubsection{Análise química das soluções obtidas com a purificação em resina de troca iônica}

A determinação das quantidades de $\mathrm{Fe}, \mathrm{Cu}, \mathrm{Ni}$ e $\mathrm{Zn}$ foram realizadas por ICP-OES.

Utilizou-se água purificada para diluição das amostras, preparações do branco e dos padrões.

As soluções obtidas com o estudo do comportamento do $\mathrm{Cu}, \mathrm{Ni}$ e $\mathrm{Zn}$ em resina aniônica, item 4.2.7.1, foram diluídas 1:100 com água purificada e as curvas de calibração foram construídas no intervalo de 2-10 $\mu \mathrm{g} \mathrm{mL}^{-1}$ a partir da diluição de padrões de $100 \mu \mathrm{g}$ $\mathrm{mL}^{-1}$ de cada íon.

As soluções obtidas com a difusão térmica dos alvos irradiados, provenientes da separação química em resina aniônica, item 4.2.7.3, e da separação química em resina catiônica, item 4.2.8, foram diluídas na razão 1:10, com curvas de calibração construídas no intervalo de 0,2-1,0 $\mu \mathrm{g} \mathrm{m}^{-1}$.

\subsubsection{Determinação da pureza radioquímica do ${ }^{67} \mathrm{Ga}$}

A pureza radioquímica de um radiofármaco é expressa pela percentagem de atividade de um radionuclídeo na forma química desejada, relativamente à atividade total do radionuclídeo ${ }^{(11)}$

As impurezas radioquímicas têm origem na decomposição dos radiofármacos, devido à ação do solvente, temperatura, $\mathrm{pH}$, luz, presença de agentes oxidantes ou redutores, radiólise. A presença de impurezas radioquímicas nas preparações radiofarmacêuticas diminui a qualidade da imagem e aumenta a dose de radiação para o paciente. As impurezas radioquímicas são determinadas por métodos analíticos, tais como cromatografia em papel, camada delgada, eletroforese e cromatografia líquida de alta eficiência ${ }^{(11)}$.

A pureza radioquímica do ${ }^{67} \mathrm{Ga}$ foi verificada por cromatografia ascendente em papel utilizando como suporte papel Whatman $3 \mathrm{MM}(1,5 \times 8,0 \mathrm{~cm})$ e fase móvel a 
mistura Piridina:Etanol:Água purificada (1:2:4). Neste sistema cromatográfico, o Fator de Retenção (Rf) para o ${ }^{67} \mathrm{GaCl}_{3}$ é 0,0 e para os complexos Citrato/Acetato- ${ }^{67} \mathrm{Ga}$ é $0,8{ }^{(108)}$.

Após o desenvolvimento das fitas cromatográficas, elas foram secas em estufa, cortadas em 7 segmentos de $0,5 \mathrm{~cm}$ e cada segmento teve sua atividade radioativa determinada em contador gama tipo poço por 20 segundos, em janela com energia de 200-500 KeV.

A pureza radioquímica foi verificada para o item 4.2.7.2 com determinação da quantidade de Acetato de ${ }^{67} \mathrm{Ga}$ quando adicionou-se $\mathrm{HAc}$ na amostra de ${ }^{67} \mathrm{GaCl}_{3}$ (NORDION) e também a quantidade de Cloreto na amostra retomada em $\mathrm{HCl} \mathrm{0,1} \mathrm{mol} \mathrm{L}^{-1}$.

Para os itens 4.2.7.3 e 4.2.8 a pureza radioquímica foi determinada na fração retomada em $\mathrm{HCl} 0,1 \mathrm{~mol} \mathrm{~L}^{-1}$ para verificação do Cloreto de ${ }^{67} \mathrm{Ga}$.

\subsubsection{Determinação da pureza radionuclídica do ${ }^{67} \mathrm{Ga}$}

A pureza radionuclídica é a porcentagem de atividade do radionuclídeo considerado relativo à atividade total, que pode ser devido à contaminação por outros radionuclídeos (11)

A presença de eventuais impurezas radionuclídicas está relacionada com o modo de produção do radionuclídeo. Estas impurezas radionuclídicas aumentam a dose de radiação para o paciente e podem interferir na qualidade das imagens ${ }^{(11)}$.

A pureza radionuclídica é determinada por espectrometria $\gamma$, utilizando-se um detector de Germânio Hiper-Puro, pela medição da energia, do tipo de radiações emitidas pelo radiofármaco e a quantificação desses emissores em relação ao radioisótopo de interesse ${ }^{(11)}$.

A TAB. 13 descreve as características de decaimento dos radionuclídeos observados na produção de ${ }^{67} \mathrm{Ga}$ utilizando-se alvos de zinco natural eletrodepositados em uma placa de cobre niquelado ${ }^{(109)}$.

Verificaram-se os picos de energia mais abundantes (keV) para cada radionuclídeo. 
TABELA 13 - Radionuclídeos provenientes da irradiação de alvos de ${ }^{\text {nat }} \mathrm{Zn}$ em substrato de cobre niquelado ${ }^{(109)}$

\begin{tabular}{lccc}
\hline Composição & Radionuclídeo & Meia-Vida & $\mathrm{E} \gamma(\mathrm{keV})$ \\
\hline Zinco Natural $-{ }^{64,66,67,68,70} \mathrm{Zn}$ & ${ }^{67} \mathrm{Ga}$ & 78 horas & 184 \\
& ${ }^{66} \mathrm{Ga}$ & 9,49 horas & 1039 \\
& ${ }^{65} \mathrm{Zn}$ & 245 dias & 1115,55 \\
\hline Níquel Natural $-{ }^{58,60,61,62,64} \mathrm{Ni}$ & ${ }^{57} \mathrm{Ni}$ & 36 horas & 1377,63 \\
& ${ }^{57} \mathrm{Co}$ & 271,3 dias & 122,56 \\
& ${ }^{55} \mathrm{Co}$ & 17,54 horas & 931,10 \\
& ${ }^{56} \mathrm{Co}$ & 78,76 dias & 846,77 \\
& ${ }^{58} \mathrm{Co}$ & 70,78 dias & 810,77 \\
\hline Cobre natural $-{ }^{63,65} \mathrm{Cu}$ & ${ }^{62} \mathrm{Zn}$ & 9,3 horas & 596,63 \\
& ${ }^{65} \mathrm{Zn}$ & 245 dias & 1115,55 \\
\hline
\end{tabular}

\subsubsection{Preparação de citrato de ${ }^{67} \mathrm{Ga}$}

$\mathrm{O}^{67} \mathrm{GaCl}_{3}$ obtido no item 4.2.8 foi convertido para a forma de citrato, como se segue: a $1 \mathrm{~mL}$ da solução de ${ }^{67} \mathrm{GaCl}_{3}$ adicionou-se $3 \mathrm{~mL}$ de solução de citrato de sódio $3,8 \%$.

Após 1 hora de reação, o produto marcado teve sua Pureza Radioquímica verificada por cromatografia em papel utilizando como suporte papel Whatman 3MM $(1,5 \times 8,0 \mathrm{~cm})$ e fase móvel solução de Acetato de Sódio 0,16 $\mathrm{mol} \mathrm{L}^{-1}$. Neste sistema cromatográfico, o Fator de Retenção (Rf) para o ${ }^{67} \mathrm{GaCl}_{3}$ é 0,0 e para os complexos Citrato- ${ }^{67} \mathrm{Ga}$ é $0,9{ }^{(20)}$. Conforme a USP a pureza radioquímica deve ser superior a $97 \%$.

Após o desenvolvimento das fitas cromatográficas, elas foram secas em estufa, encapadas com fita crepe e sua atividade radioativa determinada em contador linear por 1 minuto.

Após a leitura no contador linear, as fitas cromatográficas foram cortadas em 7 segmentos de $0,5 \mathrm{~cm}$ e cada segmento teve sua atividade radioativa determinada em contador gama tipo poço por 20 segundos, em janela com energia de 200-500 KeV. 


\subsubsection{Análise estatística}

Os resultados foram expressos como Média \pm Desvio Padrão para $n \geq 3$. A análise estatística foi realizada através do programa estatístico ASSISTAT (Assistat 7.6, Santos e Silva, DEAG-CTRN-UFCG, Campina Grande, Paraíba, Brasil). O nível de significância ( $\alpha$ ) foi de 0,05 para todos os testes estatísticos.

Calculou-se também o coeficiente de variação, CV. O coeficiente de variação é uma medida de dispersão empregada para estimar a precisão de experimentos e representa o desvio-padrão expresso como porcentagem da média. O CV é obtido pelo desvio-padrão dividido pela média, multiplicado por 100: ${ }^{(110)}$

$$
C V=\underline{\sigma \times 100}
$$

\section{$\mu$}

O coeficiente de variação fornece a variação dos dados obtidos em relação à média. Quanto menor for o seu valor, mais homogêneos e precisos serão os dados. 0 coeficiente de variação é considerado baixo (apontando um conjunto de dados bem homogêneos) quando for menor ou igual a $25 \%$ e é considerado moderado quando estiver entre 25 e $50 \%{ }^{(110)}$. 


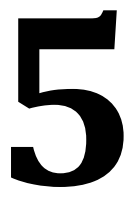

\section{RESUltados E DiscuSSões}

\subsection{Preparo de alvos por eletrodeposição}

Os depósitos de zinco obtidos foram aderentes ao substrato, levemente brilhantes, sem aspecto esponjoso e não houve necessidade de tratamentos posteriores. As FIG. 15 e FIG 16 ilustram os depósitos obtidos nas duas geometrias utilizadas.

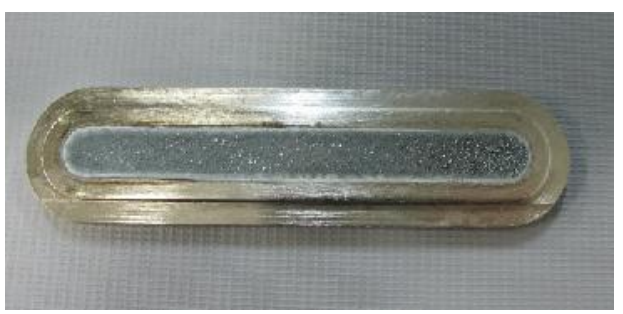

FIGURA. 15 - Placa Contendo Zn eletrodepositado para estudos de difusão $(12 \times 3 \mathrm{~cm})$

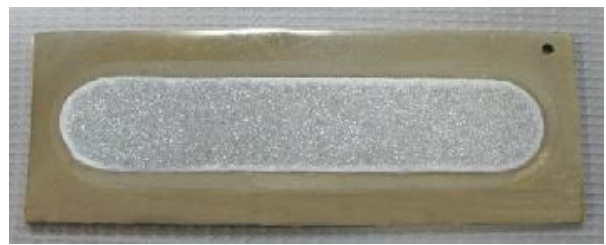

FIGURA. 16 - Alvo de Zn eletrodepositado para irradiação $(7 \times 2,7 \mathrm{~cm})$ 
Nas TAB. 14 e TAB. 15 são apresentados os resultados obtidos para as eletrodeposições de $\mathrm{Zn}$ realizadas: massa de $\mathrm{Zn}$ presente em cada eletrólito, massa de zinco calculada conforme item 1.2.3 massa de depósito obtida, rendimento do processo, eficiência de corrente calculada conforme item 1.2.3 médias e desvios-padrões encontrados.

TABELA 14 - Resultados da eletrodeposição de Zn em placas para difusão

\begin{tabular}{|c|c|c|c|}
\hline \multicolumn{4}{|c|}{ Massa Zn Eletrólito = 1,48 g } \\
\hline \multicolumn{4}{|c|}{ Massa Teórica = 1,01 g } \\
\hline Placa & Massa (g) & Rendimento (\%) * & Efic. Corrente (\%) ** \\
\hline 1 & 0,79 & 53 & 78 \\
\hline 2 & 0,82 & 55 & 81 \\
\hline 3 & 0,82 & 55 & 81 \\
\hline 4 & 0,78 & 53 & 77 \\
\hline 5 & 0,90 & 61 & 89 \\
\hline 6 & 0,82 & 56 & 81 \\
\hline 7 & 0,79 & 53 & 78 \\
\hline 8 & 0,83 & 56 & 82 \\
\hline 9 & 0,87 & 59 & 86 \\
\hline 10 & 0,91 & 62 & 91 \\
\hline 11 & 0,82 & 56 & 81 \\
\hline 12 & 0,84 & 57 & 84 \\
\hline Média & 0,83 & 56 & 83 \\
\hline$D P$ & 0,04 & 3 & 4 \\
\hline$C V(\%)$ & 4,8 & 5,4 & 4,8 \\
\hline
\end{tabular}

* Rendimento de eletrodeposição em relação à massa de zinco presente no eletrólito.

** Eficiência de Corrente em relação à massa teórica (Equações 1, 2 e 3, páginas 9 e 10). 
TABELA 15 - Resultados da eletrodeposição de Zn em placas para irradiação

\begin{tabular}{|c|c|c|c|c|c|c|}
\hline \multirow[b]{3}{*}{ PLACA } & \multicolumn{6}{|c|}{ Massa $\mathrm{Zn}$ Eletrólito = 1,04 g } \\
\hline & \multicolumn{3}{|c|}{$\begin{array}{c}\text { Massa Teórica }=1,46 \mathrm{~g} \\
\text { Tempo de Processo: } 4 \text { horas }\end{array}$} & \multicolumn{3}{|c|}{$\begin{array}{c}\text { Massa Teórica }=0,73 \mathrm{~g} \\
\text { Tempo de Processo: } 2 \text { horas }\end{array}$} \\
\hline & $\begin{array}{c}\text { Massa } \\
\text { (g) }\end{array}$ & $\begin{array}{c}\text { Rendimento } \\
\text { (\%)* }\end{array}$ & $\begin{array}{l}\text { Efic. Corrente } \\
\qquad(\%) * *\end{array}$ & $\begin{array}{c}\text { Massa } \\
\text { (g) }\end{array}$ & $\begin{array}{c}\text { Rendimento } \\
(\%) *\end{array}$ & $\begin{array}{l}\text { Efic. Corrente } \\
\text { (\%) ** }\end{array}$ \\
\hline 1 & 0,39 & 38 & 27 & 0,48 & 46 & 66 \\
\hline 2 & 0,41 & 39 & 28 & 0,47 & 45 & 64 \\
\hline 3 & 0,42 & 40 & 28 & 0,35 & 34 & 48 \\
\hline 4 & 0,42 & 41 & 29 & 0,47 & 46 & 65 \\
\hline 5 & 0,42 & 41 & 29 & 0,44 & 43 & 61 \\
\hline 6 & 0,40 & 39 & 28 & 0,46 & 44 & 63 \\
\hline 7 & 0,43 & 41 & 29 & 0,51 & 49 & 70 \\
\hline 8 & 0,44 & 42 & 30 & 0,47 & 45 & 65 \\
\hline 9 & 0,43 & 42 & 30 & 0,47 & 45 & 65 \\
\hline 10 & 0,42 & 40 & 28 & 0,49 & 47 & 67 \\
\hline 11 & 0,43 & 41 & 29 & & & \\
\hline 12 & 0,42 & 40 & 29 & & & \\
\hline 13 & 0,41 & 40 & 28 & & & \\
\hline 14 & 0,45 & 43 & 31 & & & \\
\hline 15 & 0,38 & 37 & 26 & & & \\
\hline 16 & 0,80 & 77 & 55 & & & \\
\hline 17 & 0,77 & 75 & 53 & & & \\
\hline Média*** & 0,42 & 40 & 29 & 0,49 & 44 & 63 \\
\hline$D P$ & 0,02 & 2 & 1 & 0,04 & 1 & 2 \\
\hline$C V(\%)$ & 4,8 & 5,0 & 3,4 & 8,2 & 2,3 & 3,2 \\
\hline
\end{tabular}

* Rendimento de eletrodeposição em relação à massa de zinco presente no eletrólito.

** Eficiência de Corrente em relação à massa teórica (Equações 1, 2 e 3, páginas 9 e 10).

*** Média e DP calculados com os dados das placas de 1 a 15. 
A eletrodeposição de zinco nas Placas para Difusão apresentou um baixo Rendimento de Processo de (56 \pm 3 )\% e uma boa Eficiência Catódica de (83 \pm 4 )\%, uma vez que uma parte da corrente provavelmente foi consumida pela redução paralela do hidrogênio, observada pela liberação de gases. A massa de zinco presente na solução eletrolítica estava aproximadamente $\mathbf{4 7 \%}$ superior à massa necessária. Este excesso de massa e de íons na solução pode ser o responsável pelos desvios encontrados.

Apesar do baixo rendimento, os depósitos obtidos foram aderentes ao substrato, levemente brilhantes e as massas obtidas - $(0,83 \pm \mathbf{0 , 0 4}) \mathrm{g}(\mathrm{n}=12)$ - foram adequadas aos estudos realizados e estão de acordo com o método utilizado no IPEN, onde a massa de zinco eletrodepositada está entre 0,60-0,80 $\mathrm{g}^{(17)}$.

CHAMMA $^{\left({ }^{(8)}\right.}$ e SANTOS ${ }^{(94)}$ utilizaram uma massa de $\mathrm{Zn}$ depositada em torno de 0,40-0,50 g nas Placas para Irradiação $(7 \times 2,7 \mathrm{~cm})$. Inicialmente, esta massa foi obtida com 4 horas de processo, $(0,42 \pm \mathbf{0 , 0 2}) \mathbf{g}(n=15)$. Ao se observar um aumento da massa de $\mathrm{Zn}$ depositada (Placas 16 e 17) o processo passou a ser realizado com 2 horas de eletrodeposição, $(0,49 \pm \mathbf{0 , 0 4}) \mathrm{g}(\mathrm{n}=10)$.

O rendimento do processo não mostrou diferenças significativas para os tempos diferentes de eletrodeposição, $(\mathbf{4 0} \pm 2) \%$ para 4 horas de processo e $(44 \pm 1) \%$ para 2 horas de processo.

O processo com 4 horas de duração apresentou baixa eficiência catódica de $(29 \pm$ 1)\%, enquanto que para o processo com 2 horas de duração mostrou (63 \pm 2$) \%$. Foi observada visualmente uma maior liberação de hidrogênio em comparação à eletrodeposição das placas maiores.

Uma melhoria na eficiência catódica pode ser obtida com o uso de aditivos para evitar o acúmulo de hidrogênio no cátodo ou com uma agitação eficiente, por exemplo ${ }^{(7)}$.

Apesar dos baixos rendimentos de processo, este se mostrou reprodutível, verificado pelos baixos coeficientes de variação encontrados.

A uniformidade da camada depositada foi verificada por micrometria nas placas para irradiações, com 2 horas de processo.

Realizaram-se 6 medições da espessura distribuídas sobre a área eletrodepositada de cada placa. Os valores obtidos são apresentados na TAB. 16. 
TABELA 16 - Análise da espessura da camada de Zn eletrodepositado em placas para irradiação

\begin{tabular}{cc}
\hline PLACA & ESPESSURA (mm) \\
\hline $\mathbf{1}$ & $0,13 \pm 0,01$ \\
$\mathbf{2}$ & $0,13 \pm 0,01$ \\
$\mathbf{3}$ & $0,10 \pm 0,01$ \\
$\mathbf{4}$ & $0,13 \pm 0,01$ \\
$\mathbf{5}$ & $0,12 \pm 0,01$ \\
$\mathbf{6}$ & $0,13 \pm 0,01$ \\
$\mathbf{7}$ & $0,15 \pm 0,01$ \\
$\mathbf{8}$ & $0,13 \pm 0,01$ \\
$\mathbf{9}$ & $0,16 \pm 0,04$ \\
$\mathbf{1 0}$ & $0,13 \pm 0,01$ \\
\hline Média & $\mathbf{0 , 1 3} \pm 0,01$ \\
\hline CV(\%) & $\mathbf{7 , 7}$ \\
\hline
\end{tabular}

O depósito ideal para irradiação deve ser fortemente aderente e uniformemente distribuído sobre a superfície do suporte. Devem-se evitar depósitos esponjosos, porosos que se soltam facilmente do suporte, pois promovem perdas de rendimento na irradiação dos alvos e geram contaminantes no processo de separação química. Um pré-requisito importante na preparação de alvos sólidos para irradiação é um desvio padrão de $\pm 5 \%$ na espessura média ${ }^{(8)}$.

Em ambas as condições de deposição, os depósitos obtidos foram aderentes ao substrato, levemente brilhantes, com massas obtidas adequadas aos estudos e as irradiações necessárias.

Os resultados apresentados na TAB. 18 mostraram ótima uniformidade e homogeneidade dos depósitos obtidos, confirmados pelo baixo coeficiente de variação encontrado na medida da espessura.

A análise morfológica da superfície do depósito foi realizada por MEV com a obtenção de micrografias com ampliações de 25 e 1000 vezes. 


\section{Capítulo $5 \mid 68$ \\ Resultados e Discussões}

As FIG. 17 e FIG. 18 mostram as micrografias da camada de $\mathrm{Zn}$ que revelaram uma superfície com um relevo nodular, com grãos hexagonais distribuídos uniformemente por toda extensão do depósito.

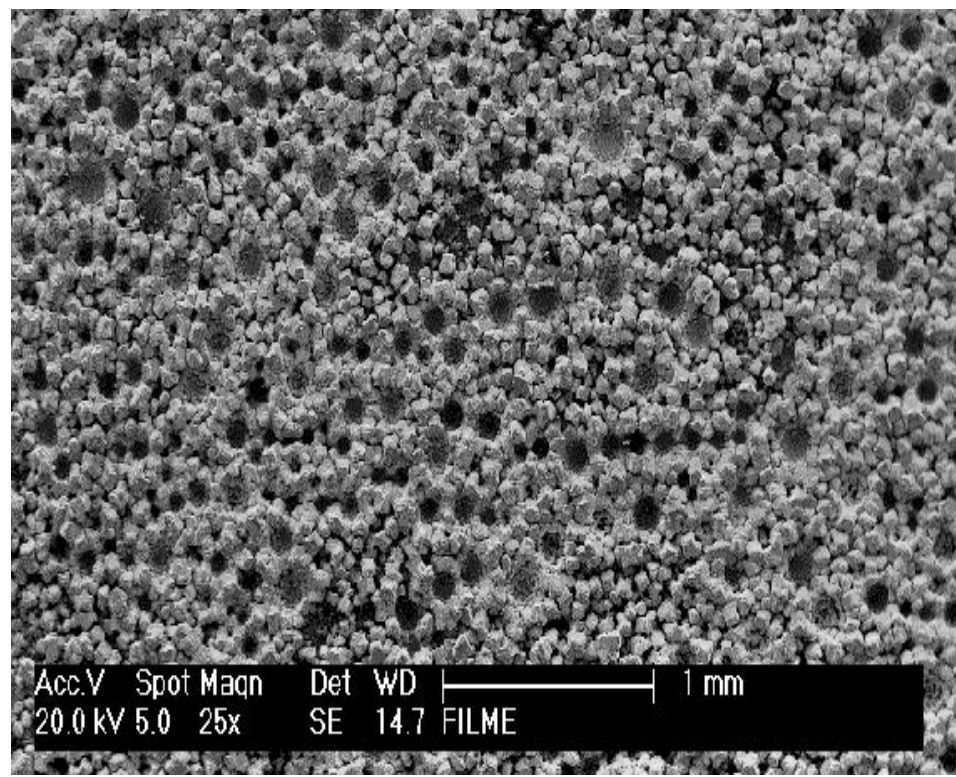

FIGURA 17 - Micrografia de Zn com ampliação de 25 vezes

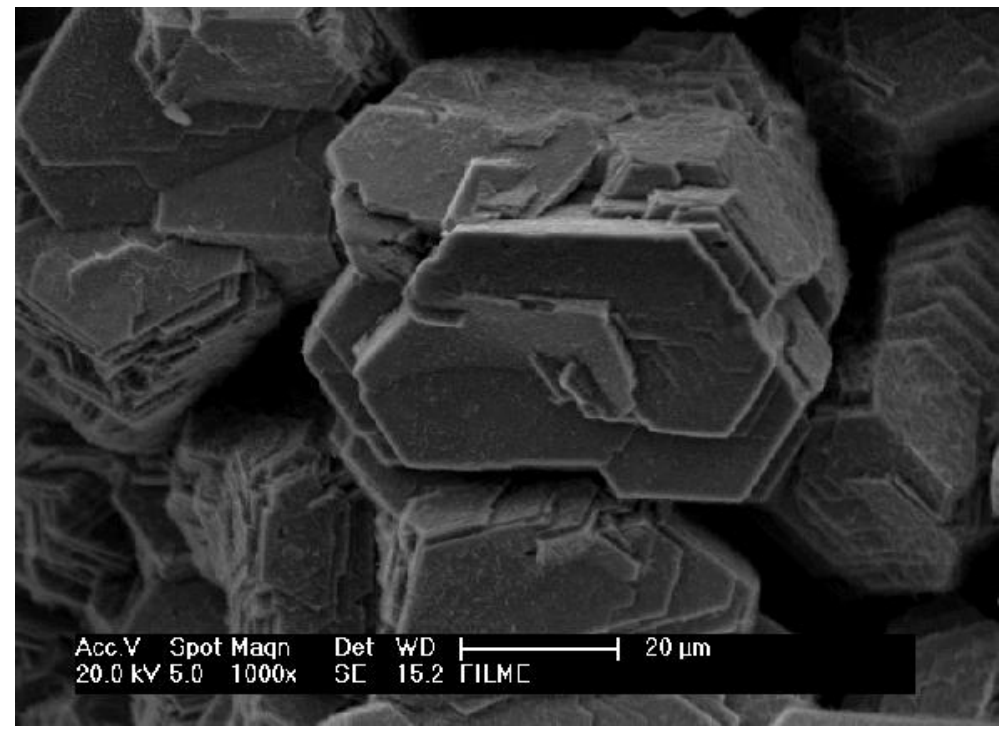

FIGURA 18 - Micrografia de Zn com ampliação de 1000 vezes 
5.2 Resultados da difusão térmica em placas de cobre, placas de cobre niquelada e placas contendo depósito de zinco não irradiadas

Todas as placas foram pesadas antes e depois do procedimento de aquecimento seguido da extração em HAc. Estes ensaios foram realizados para verificar a liberação e dissolução dos metais zinco, níquel e cobre em HAc, em função da temperatura.

Nas TAB. 17, TAB. 18 e TAB. 19 são possíveis verificar a diferença de massa das placas estudadas quando submetidas a diferentes temperaturas, em diferentes tempos de aquecimento e depois ao contato com HAc.

TABELA 17 - Diferença de massa nas placas de cobre $(\mathrm{Cu})(\mathrm{n}=3)$

\begin{tabular}{|c|c|c|c|}
\hline $\begin{array}{l}\text { Temperatura de } \\
\text { Aquecimento }\left({ }^{\circ} \mathrm{C}\right)\end{array}$ & $\begin{array}{c}\text { Tempo de } \\
\text { Aquecimento }\end{array}$ & $\begin{array}{l}\text { Tempo de Extração } \\
\text { em Ácido Acético }\end{array}$ & $\begin{array}{c}\text { Diferença de } \\
\text { massa (g) }\end{array}$ \\
\hline 25 & & $\begin{array}{l}30 \text { min } \\
1 \text { hora } \\
2 \text { horas }\end{array}$ & $\begin{array}{l}-0,001 \\
-0,003 \\
-0,003\end{array}$ \\
\hline 100 & $30 \mathrm{~min}$ & $\begin{array}{l}30 \text { min } \\
1 \text { hora } \\
2 \text { horas }\end{array}$ & $\begin{array}{l}-0,003 \\
-0,004 \\
-0,008\end{array}$ \\
\hline & 1 hora & $\begin{array}{l}30 \text { min } \\
1 \text { hora } \\
2 \text { horas }\end{array}$ & $\begin{array}{l}-0,009 \\
-0,008 \\
-0,010\end{array}$ \\
\hline & 2 horas & $\begin{array}{l}30 \text { min } \\
1 \text { hora } \\
2 \text { horas }\end{array}$ & $\begin{array}{l}-0,005 \\
-0,007 \\
-0,011\end{array}$ \\
\hline 200 & $30 \mathrm{~min}$ & $\begin{array}{l}30 \text { min } \\
1 \text { hora } \\
2 \text { horas }\end{array}$ & $\begin{array}{l}-0,014 \\
-0,023 \\
-0,034\end{array}$ \\
\hline
\end{tabular}


TABELA 18 - Diferença de massa nas placas de cobre niquelada $(\mathrm{Ni} / \mathrm{Cu})(\mathrm{n}=3)$

\begin{tabular}{|c|c|c|c|}
\hline $\begin{array}{l}\text { Temperatura de } \\
\text { Aquecimento }\left({ }^{\circ} \mathrm{C}\right)\end{array}$ & $\begin{array}{c}\text { Tempo de } \\
\text { Aquecimento }\end{array}$ & $\begin{array}{l}\text { Tempo de Extração } \\
\text { em Ácido Acético }\end{array}$ & $\begin{array}{c}\text { Diferença de } \\
\text { Massa (g) }\end{array}$ \\
\hline \multirow[t]{3}{*}{25} & & $30 \mathrm{~min}$ & $-0,016$ \\
\hline & & 1 hora & $-0,007$ \\
\hline & & 2 horas & $-0,014$ \\
\hline \multirow[t]{9}{*}{100} & $30 \mathrm{~min}$ & $30 \mathrm{~min}$ & $-0,003$ \\
\hline & & 1 hora & $-0,003$ \\
\hline & & 2 horas & $-0,001$ \\
\hline & 1 hora & $30 \mathrm{~min}$ & $-0,009$ \\
\hline & & 1 hora & $-0,002$ \\
\hline & & 2 horas & $-0,014$ \\
\hline & 2 horas & $30 \mathrm{~min}$ & $-0,010$ \\
\hline & & 1 hora & $-0,002$ \\
\hline & & 2 horas & $-0,034$ \\
\hline \multirow[t]{9}{*}{200} & $30 \mathrm{~min}$ & $30 \mathrm{~min}$ & $-0,010$ \\
\hline & & 1 hora & $-0,003$ \\
\hline & & 2 horas & $-0,005$ \\
\hline & 1 hora & $30 \mathrm{~min}$ & $-0,008$ \\
\hline & & 1 hora & $-0,004$ \\
\hline & & 2 horas & $-0,015$ \\
\hline & 2 horas & $30 \mathrm{~min}$ & $-0,008$ \\
\hline & & 1 hora & $-0,009$ \\
\hline & & 2 horas & $-0,003$ \\
\hline
\end{tabular}


TABELA 19 - Diferença de massa nas placas contendo depósito de zinco $(\mathrm{Zn} / \mathrm{Ni} / \mathrm{Cu})(\mathrm{n}=3)$

\begin{tabular}{|c|c|c|c|}
\hline $\begin{array}{l}\text { Temperatura de } \\
\text { Aquecimento }\left({ }^{\circ} \mathrm{C}\right)\end{array}$ & $\begin{array}{c}\text { Tempo de } \\
\text { Aquecimento }\end{array}$ & $\begin{array}{l}\text { Tempo de Extração } \\
\text { em Ácido Acético }\end{array}$ & $\begin{array}{c}\text { Diferença de } \\
\text { Massa (g) }\end{array}$ \\
\hline \multirow[t]{3}{*}{25} & & $30 \mathrm{~min}$ & $+0,009$ \\
\hline & & 1 hora & $+0,017$ \\
\hline & & 2 horas & $-0,020$ \\
\hline \multirow[t]{9}{*}{100} & $30 \mathrm{~min}$ & $30 \mathrm{~min}$ & $-0,011$ \\
\hline & & 1 hora & $+0,001$ \\
\hline & & 2 horas & $-0,006$ \\
\hline & 1 hora & $30 \mathrm{~min}$ & $-0,033$ \\
\hline & & 1 hora & $-0,010$ \\
\hline & & 2 horas & $-0,001$ \\
\hline & 2 horas & $30 \mathrm{~min}$ & $+0,002$ \\
\hline & & 1 hora & $+0,041$ \\
\hline & & 2 horas & $-0,018$ \\
\hline \multirow[t]{9}{*}{200} & $30 \mathrm{~min}$ & $30 \mathrm{~min}$ & $+0,001$ \\
\hline & & 1 hora & $-0,035$ \\
\hline & & 2 horas & $-0,014$ \\
\hline & 1 hora & $30 \mathrm{~min}$ & $-0,006$ \\
\hline & & 1 hora & $-0,010$ \\
\hline & & 2 horas & $-0,017$ \\
\hline & 2 horas & $30 \mathrm{~min}$ & $-0,012$ \\
\hline & & 1 hora & $-0,004$ \\
\hline & & 2 horas & $+0,008$ \\
\hline
\end{tabular}

Conforme visto no item 4.2.3 o efeito da temperatura para os metais em estudo ocorre nesta ordem: $\mathbf{C u}>\mathbf{Z n}>\mathbf{N i}$. A eletropositividade é a capacidade de um átomo perder elétrons, originando cátions. Para os metais em estudo a ordem de eletropositividade é: $\mathbf{Z n}>\mathbf{N i}>\mathbf{C u}$. 
As FIG. 19, 20 e 21 apresentam graficamente os resultados da diferença de massa dos 3 tipos de placas estudadas para as temperaturas de $25{ }^{\circ} \mathrm{C}, 100{ }^{\circ} \mathrm{C}$ e $200{ }^{\circ} \mathrm{C}$, respectivamente e o efeito do tempo de extração em HAc.

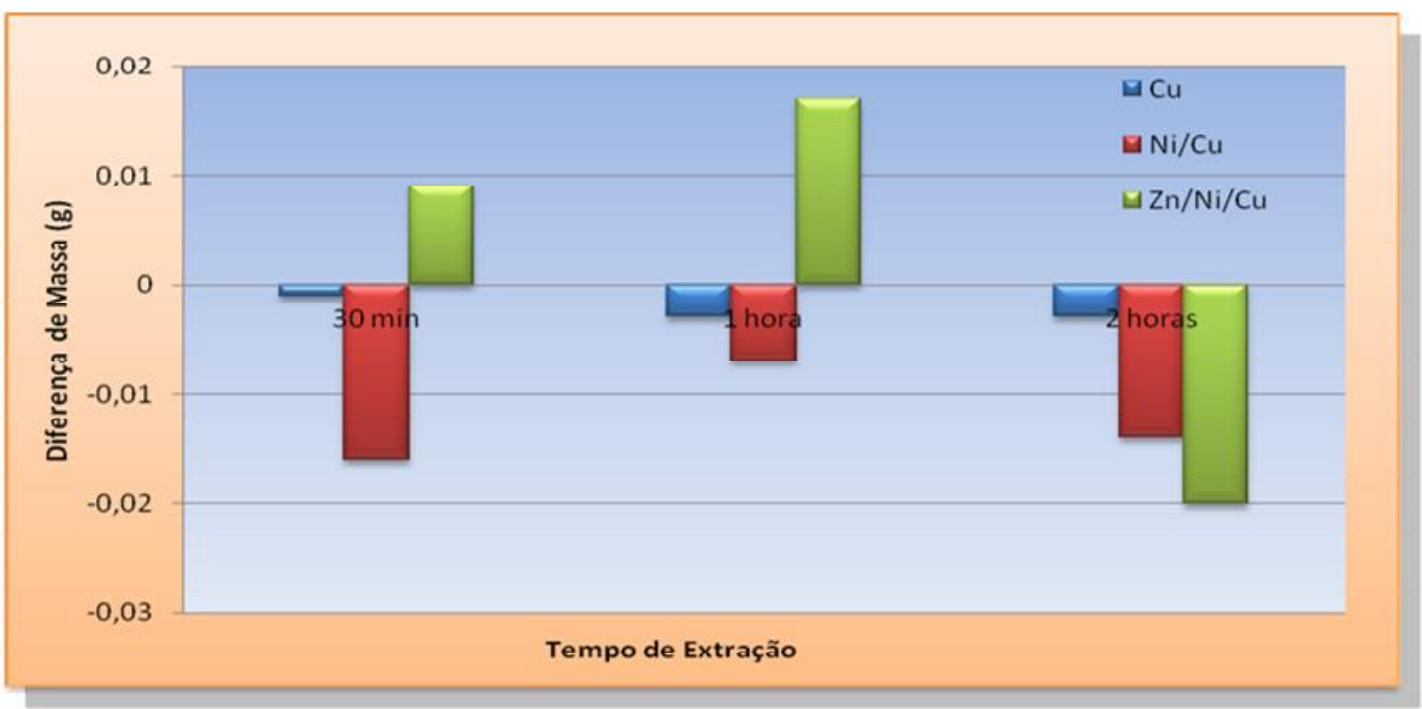

FIGURA 19 - Diferença de massa a $25^{\circ} \mathrm{C}$

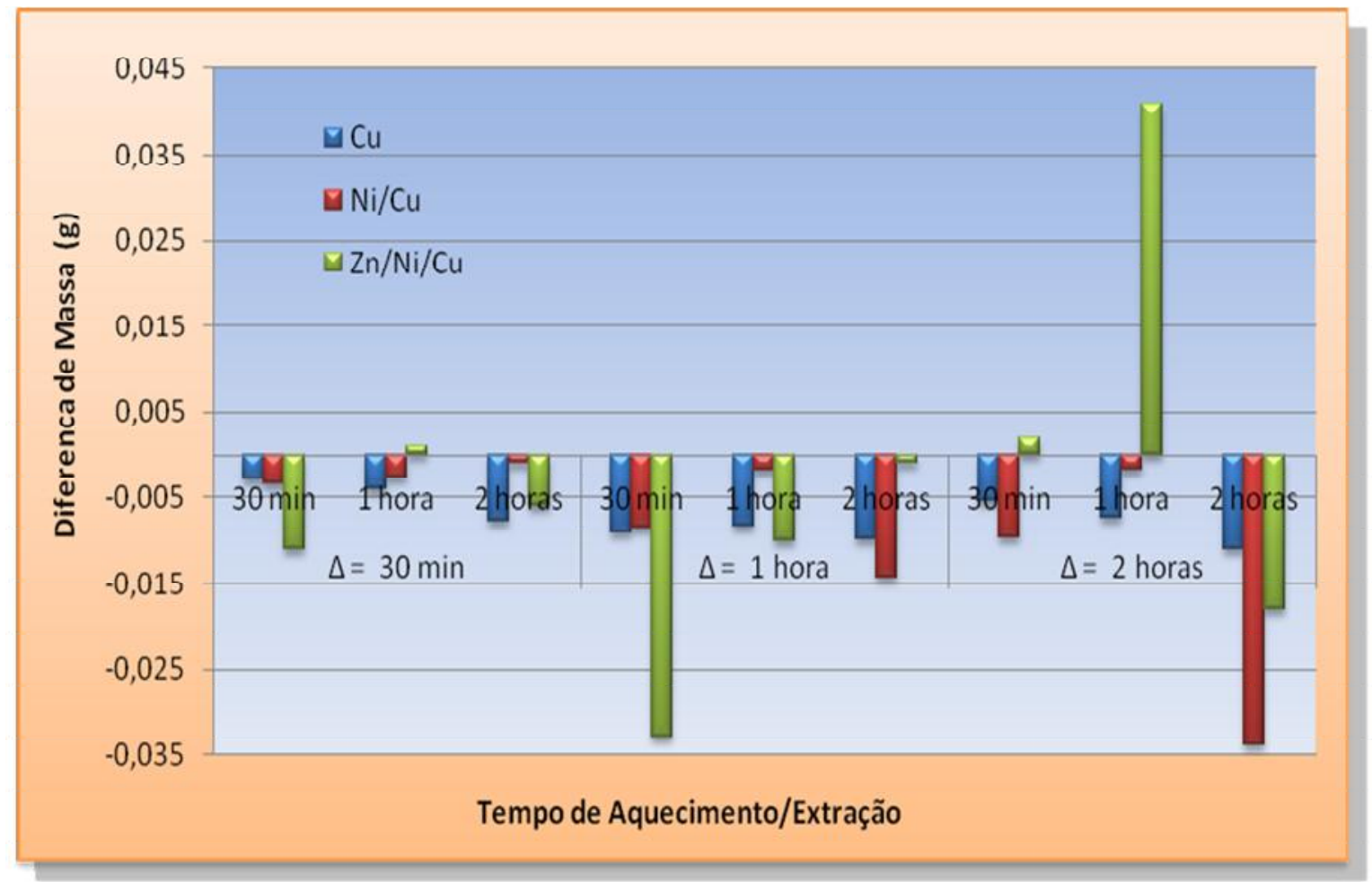

FIGURA 20 - Diferença de massa a $100{ }^{\circ} \mathrm{C}$ 


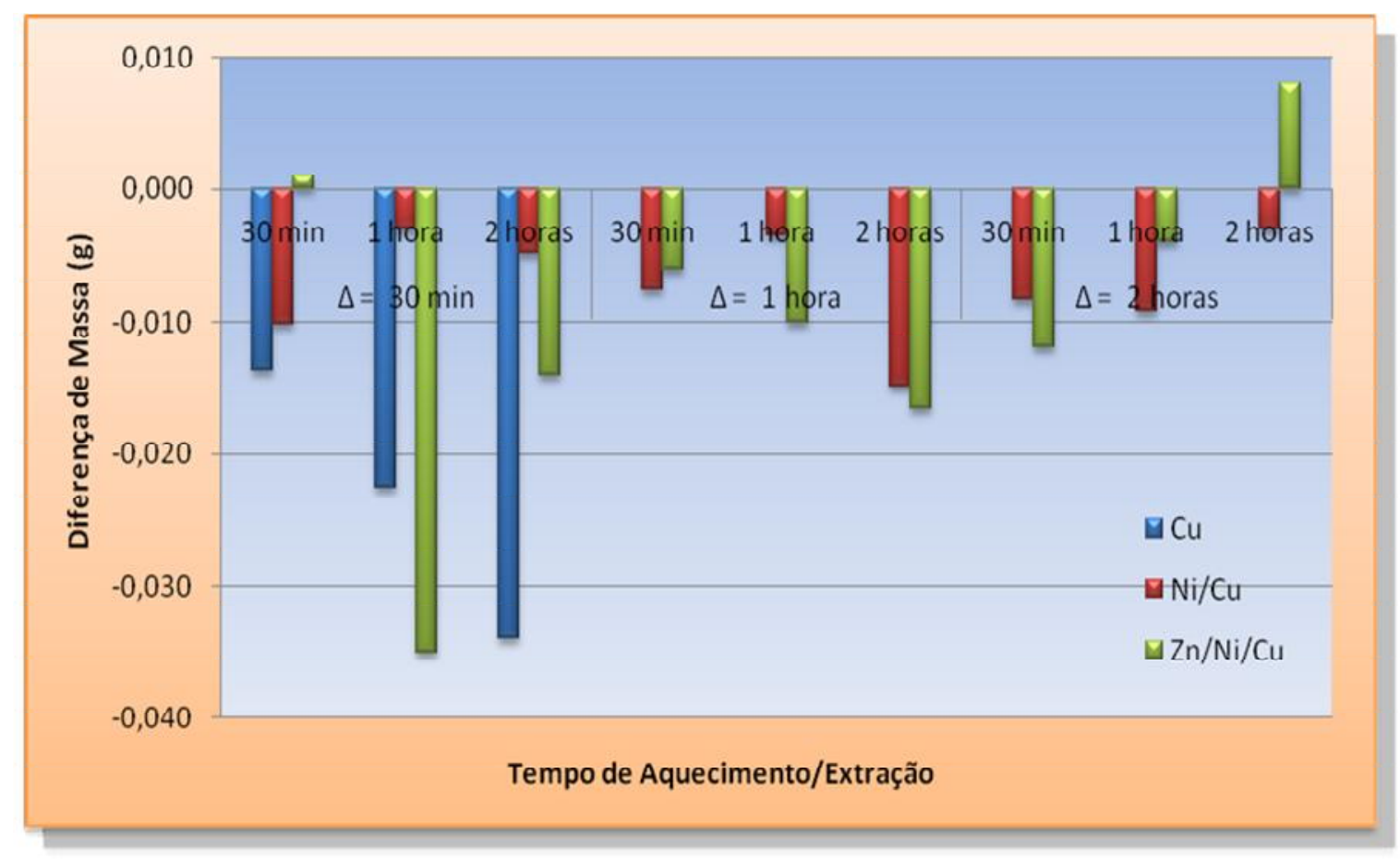

FIGURA 21 - Diferença de massa a $200^{\circ} \mathrm{C}$

Na temperatura de $25^{\circ} \mathrm{C}$, a perda de massa pela dissolução em HAc, aumentou na sequência $\mathbf{Z n}>\mathbf{N i}>\mathbf{C u}$, ou seja, placa com depósito de zinco, placa de cobre niquelada e placa de cobre (FIG. 19).

Quando aquecidas a $100{ }^{\circ} \mathrm{C}$ (FIG. 20), as placas com depósito de zinco sofreram maior dissolução no HAc, com maiores perdas de massa, e depois uma maior perda de massa das placas de cobre em relação às placas de cobre niquelada.

A condutividade térmica do cobre é maior que a do níquel o que contribuiu para uma maior solubilidade do cobre e sua maior perda de massa com o aumento da temperatura.

Os ensaios iniciais utilizaram placas de cobre com revestimento de níquel anteriormente depositado. Por haver um número reduzido de placas foi necessária a reutilização para completar a avaliação de todos os parâmetros propostos. A perda de massa de 0,034 g (FIG. 20) observada ocorreu com uma placa nesta condição, com um desgaste na camada do revestimento de níquel.

Ao se utilizar placas com revestimento de níquel recente, a perda de massa foi 
menor, mesmo quando houve reutilização e em temperaturas ou tempo de difusão maiores.

O efeito da temperatura foi mais intenso em $200{ }^{\circ} \mathrm{C}$ (FIG. 21) para as placas de cobre que apresentaram as maiores perdas de massa, assim os estudos foram realizados somente com 30 minutos de aquecimento.

Para as placas com depósito de zinco e placas de cobre niquelada, nos outros tempos de aquecimento o depósito de zinco sofreu uma maior ação do HAc e da temperatura do que o níquel.

Ocorreu o aumento de massa das placas de $\mathrm{Zn}$ em alguns experimentos. Esta situação foi observada quando se utilizou a placa pela primeira vez. Houve também desprendimento de gás $\mathrm{H}_{2}$ (hidrogênio).

\subsection{Análise química das soluções obtidas nos ensaios com placas não irradiadas}

Todas as amostras obtidas nas extrações com $\mathrm{HAc}$ tiveram $\mathrm{Cu}$, Ni e $\mathrm{Zn}$ quantificados por ICP-OES.

Nas FIG. 22, 23 e 24 é possível observar as concentrações de cobre na placa de cobre $(\mathrm{Cu})$, a concentração de níquel na placa de cobre niquelada (Ni) e a concentração de zinco $(Z n)$ e níquel $[\mathrm{Ni}(\mathrm{Zn})]$ na placa contendo o depósito de zinco, nas temperaturas de $25^{\circ} \mathrm{C}, 100{ }^{\circ} \mathrm{C}$ e $200{ }^{\circ} \mathrm{C}$, respectivamente. 


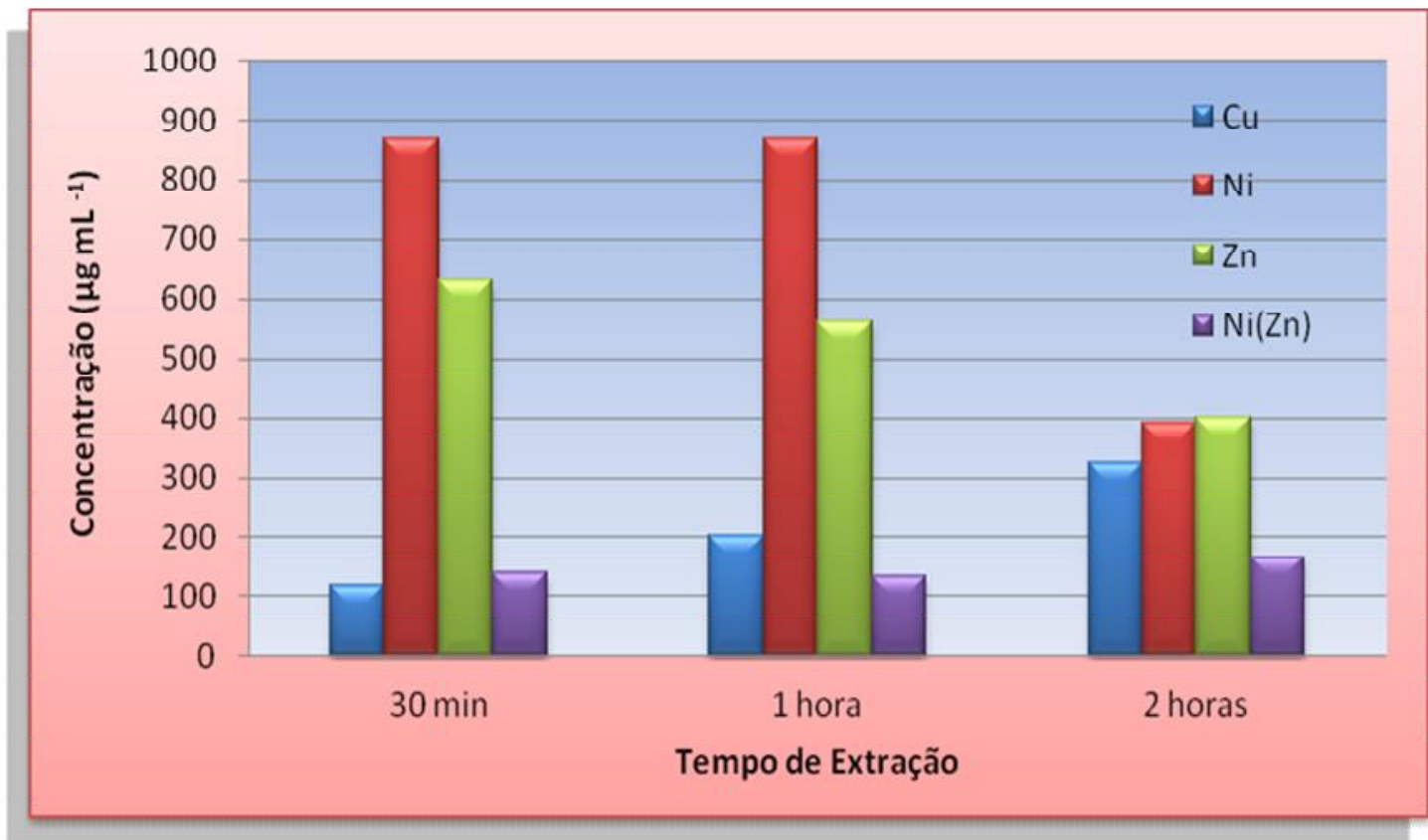

FIGURA 22 - Concentração de $\mathrm{Cu}$, Ni e Zn a $25^{\circ} \mathrm{C}$, em placas de cobre, placa de cobre niquelada e placa contendo depósito de zinco

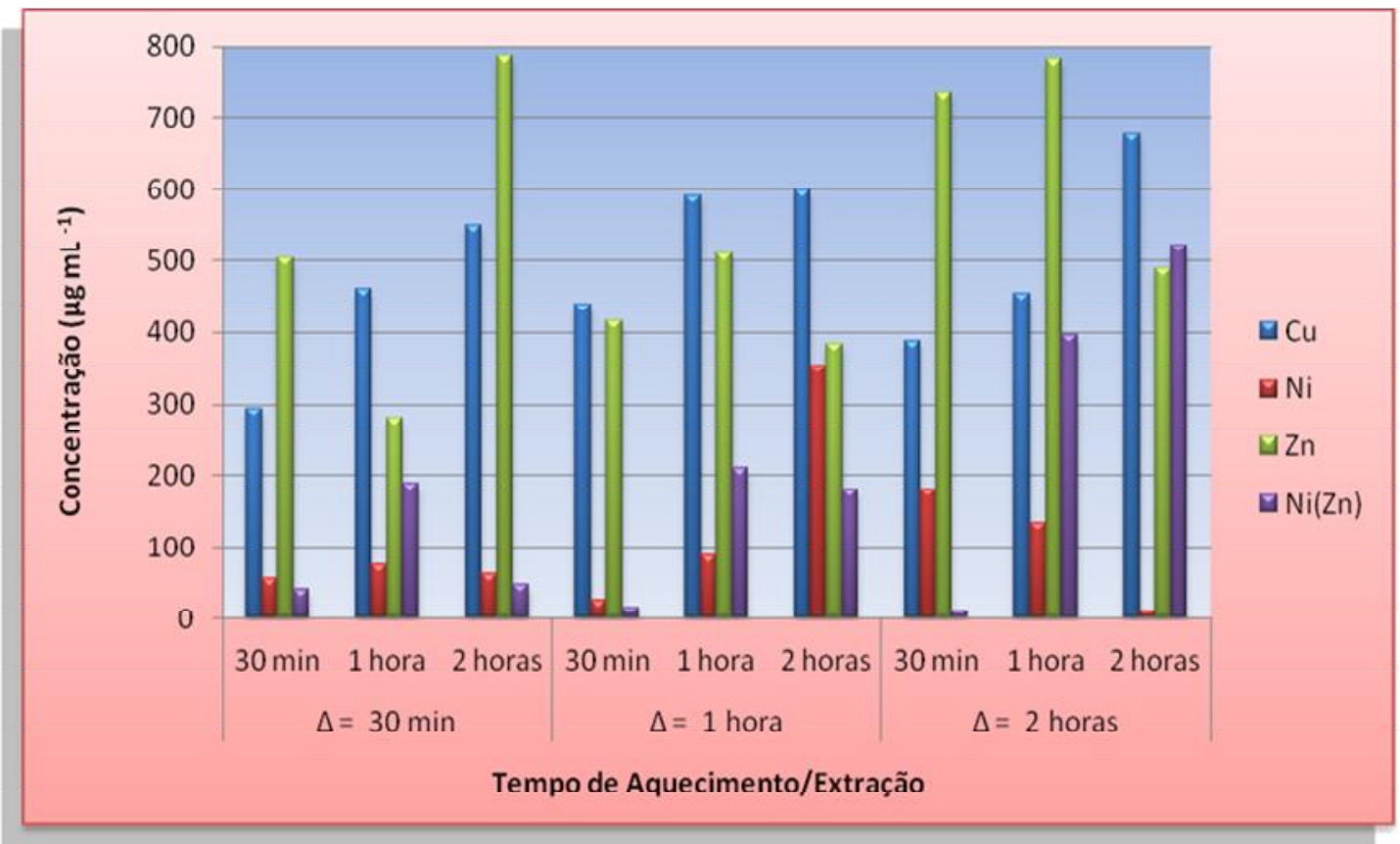

FIGURA 23 - Concentração de $\mathrm{Cu}, \mathrm{Ni}$ e $\mathrm{Zn}$ a $100^{\circ} \mathrm{C}$, em placas de cobre, placa de cobre niquelada e placa contendo depósito de zinco 


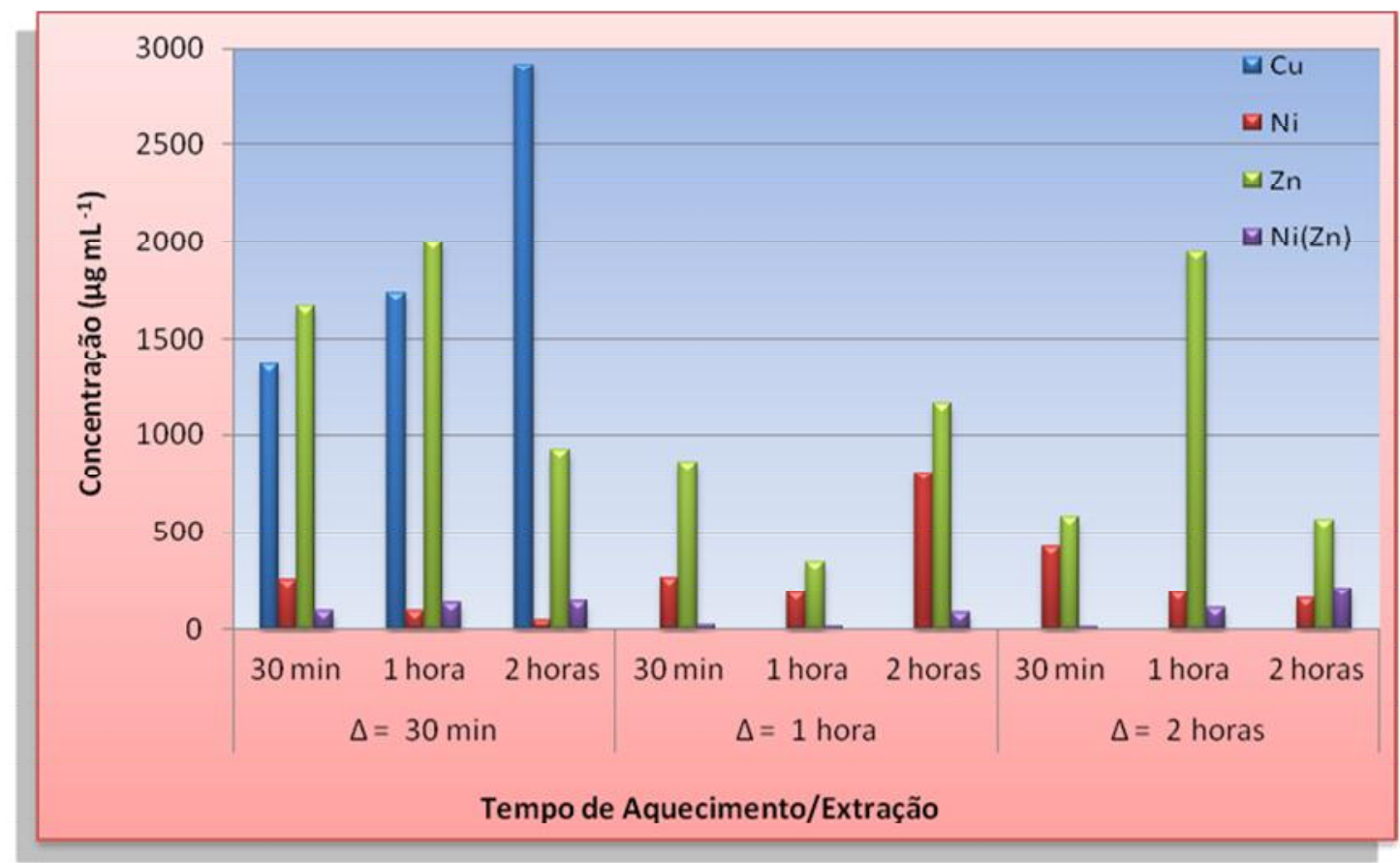

FIGURA 24 - Concentração de $\mathrm{Cu}, \mathrm{Ni}$ e $\mathrm{Zn}$ a $200^{\circ} \mathrm{C}$, em placas de cobre, placa de cobre niquelada e placa contendo depósito de zinco

$\mathrm{Na}$ análise das concentrações dos metais encontrados nas soluções de extração em HAc, é esperada a confirmação de perda de massa, como descrito no item 5.2, em função da tendência à dissolução no ácido ou da ação da temperatura no metal.

Para a temperatura de $25{ }^{\circ} \mathrm{C}$ as concentrações dos metais aumentaram na sequência $\mathrm{Ni}>\mathrm{Zn}>\mathrm{Cu}$. Observou-se que o níquel contribui para o aumento da perda total de massa nas placas contendo o deposito de zinco, como foi observado no item 5.2, FIG. 19.

O zinco é um metal mais reativo que o níquel, mas como se utilizaram placas com revestimento antigo e houve a reutilização das placas, isto contribui para uma maior perda de massa das placas de níquel.

A concentração de $\mathrm{Cu}$ foi determinada nas placas de cobre-niquelado e zinco eletrodepositado e os valores encontrados foram inferiores ao limite de detecção.

BROWN e col. ${ }^{(86)}$ verificaram problemas de integridade dos alvos quando utilizaram zinco eletrodepositado em substrato de cobre, pela formação de ligas intermetálicas $\mathrm{Zn}-\mathrm{Cu}$, durante irradiações longas com alta potência (7 horas, 11 kW). 0 
uso da camada de níquel sobre o cobre e a deposição do zinco sobre o níquel eliminou este problema e minimizou o ataque químico do alvo durante sua dissolução para extração do ${ }^{67} \mathrm{Ga}$.

Os resultados obtidos mostraram que as placas de $\mathrm{Cu}$ sofreram maior efeito da temperatura, com consequente perda de massa em HAc. Este fator restringe o uso do $\mathrm{Cu}$ como substrato para os depósitos de $\mathrm{Zn}$, pois o ${ }^{67} \mathrm{Ga}$ poderia apresentar esta impureza.

Os resultados obtidos mostraram que o aquecimento a $100^{\circ} \mathrm{C}$ por 1 hora e uma extração em ácido acético, também por 1 hora é adequado para a extração do ${ }^{67} \mathrm{Ga}$ da dos alvos de $\mathrm{Zn}$.

\subsection{Irradiações no Cyclone 30}

QUATORZE alvos de zinco natural eletrodepositado foram irradiados com prótons de $26 \mathrm{MeV}$ e corrente integrada de $10 \mu \mathrm{A}$.h.

Na TAB. 20 apresentam-se os resultados da diferença de massa dos alvos antes e após as irradiações e quanto representa quantitativamente esta perda em relação à massa inicial de zinco do alvo. A variação da perda de massa foi mínima, demonstrando boa qualidade e aderência do depósito de zinco.

TABELA 20 - Massa de alvos de ${ }^{67} \mathrm{Ga}$ após irradiação

\begin{tabular}{|c|c|c|c|c|c|}
\hline ALVO & $\begin{array}{c}\text { Massa } \\
\text { Inicial (g) }\end{array}$ & $\begin{array}{c}\text { Massa } \\
\text { Final (g) }\end{array}$ & $\begin{array}{l}\text { Diferença } \\
\text { Massa (g) }\end{array}$ & $\begin{array}{c}\text { Massa de } \\
\text { Zn (g) }\end{array}$ & $\begin{array}{c}\text { \% Diferença } \\
\text { de Massa }\end{array}$ \\
\hline 1 & 28,3212 & 28,3200 & $-0,0012$ & 0,4242 & 0,28 \\
\hline 2 & 28,6974 & 28,6967 & $-0,0007$ & 0,4155 & 0,17 \\
\hline 3 & 28,0175 & 28,0145 & $-0,0030$ & 0,4294 & 0,70 \\
\hline 4 & 27,7614 & 27,7594 & $-0,0020$ & 0,4071 & 0,49 \\
\hline 5 & 29,1132 & 29,1110 & $-0,0022$ & 0,4391 & 0,50 \\
\hline 6 & 28,9984 & 28,9971 & $-0,0013$ & 0,4337 & 0,30 \\
\hline 7 & 27,8608 & 27,8575 & $-0,0033$ & 0,4298 & 0,77 \\
\hline 8 & 28,2335 & 28,2301 & $-0,0034$ & 0,4160 & 0,82 \\
\hline 9 & 28,5573 & 28,5535 & $-0,0038$ & 0,4190 & 0,91 \\
\hline 10 & 28,7410 & 28,7392 & $-0,0018$ & 0,8000 & 0,23 \\
\hline
\end{tabular}




\begin{tabular}{rrrrrc}
11 & 28,7994 & 28,7979 & $-0,0015$ & 0,7760 & 0,19 \\
12 & 25,7060 & 25,7050 & $-0,0010$ & 0,3927 & 0,26 \\
13 & 28,7396 & 28,7406 & 0,0010 & 0,4745 & $-0,21$ \\
14 & 26,1628 & 26,1652 & $-0,0024$ & 0,4912 & 0,49 \\
\hline
\end{tabular}

A atividade obtida no EOB (End Of Bombardment) foi calculada a partir da equação abaixo $^{(2)}$ :

$\left.A=A_{0} e^{[(-0,693 \times t) / t}{ }_{1 / 2}\right]$

onde $\mathbf{A}$ é a atividade medida no tempo t; $\mathbf{A}_{0}$ é a atividade no EOB; $\mathbf{t}$ é o tempo após a irradiação e $\mathbf{t}_{1 / 2}$ é o tempo de meia-vida do radioisótopo.

Os cálculos de rendimento de produção foram feitos a partir da equação abaixo ${ }^{(2)}$ :

$\eta=\underline{A}_{0}$

i.t

onde $\eta$ é o rendimento de produção (Bq/ $/ \mu \mathrm{A} . \mathrm{h}$ ou $\mu \mathrm{Ci} / \mu \mathrm{A} . \mathrm{h}), \mathbf{A}_{0}$ é a atividade no EOB (Bq ou $\mu \mathrm{Ci})$; i é a corrente de feixe $(\mu \mathrm{A})$ e t é o tempo de irradiação (h).

Devido à espessura de irradiação do alvo, os prótons iniciais de $26 \mathrm{MeV}$ perdem energia e saem do alvo de $\mathrm{Zn}$ com $21 \mathrm{MeV}$.

SZELECSENYI e col. ${ }^{(111)}$ demonstraram os valores para o rendimento de alvo

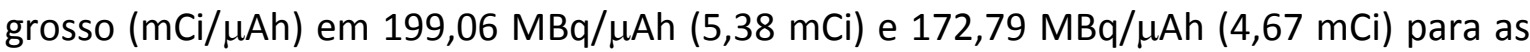
energias de 26 e $21 \mathrm{MeV}$, respectivamente. O rendimento teórico para a produção de ${ }^{67} \mathrm{Ga}$ é de $26,27 \mathrm{MBq} / \mu \mathrm{Ah}(0,71 \mathrm{mCi})$ para este intervalo de energia.

A TAB. 21 apresenta os cálculos teóricos e os resultados experimentais de rendimento da produção de ${ }^{67} \mathrm{Ga}$ a partir da reação ${ }^{67} \mathrm{Zn}(p, n){ }^{67} \mathrm{Ga}$ em alvos com dimensões de $7 \times 2,7 \mathrm{~cm}$. 
TABELA 21 - Resultados para produção de ${ }^{67} \mathrm{Ga}$

\begin{tabular}{ccccc}
\hline ALVO & $\begin{array}{c}\text { Corrente Integrada } \\
\text { (UA.h) }\end{array}$ & $\begin{array}{c}\mathrm{A}_{\text {Teórica }} \\
(\mathbf{M B q})\end{array}$ & $\begin{array}{c}\mathrm{A}_{\text {Еов }} \\
(\mathrm{MBq})\end{array}$ & $\eta$ (MBq/uA.h) \\
\hline $\mathbf{1}$ & 10 & 262,7 & 431,6 & 43,2 \\
$\mathbf{2}$ & 10 & 262,7 & 503,0 & 50,3 \\
$\mathbf{3}$ & 10 & 262,7 & 244,0 & 24,4 \\
\hline $\mathbf{4}$ & 10 & 262,7 & 240,7 & 24,1 \\
\hline $\mathbf{5}$ & 4,4 & 115,6 & 993,5 & 225,8 \\
\hline $\mathbf{6}$ & 10 & 262,7 & 593,5 & 59,4 \\
\hline $\mathbf{7}$ & 10 & 262,7 & 205,6 & 20,6 \\
\hline $\mathbf{8}$ & 9 & 236,4 & 288,5 & 32,1 \\
\hline $\mathbf{9}$ & 10 & 262,7 & 724,9 & 72,5 \\
\hline 10 & 15 & 394,1 & 174,4 & 11,6 \\
\hline 11 & 10 & 262,7 & 367,3 & 36,7 \\
\hline 12 & 10 & 262,7 & 641,0 & 64,1 \\
\hline 13 & 10 & 262,7 & 246,6 & 24,7 \\
\hline 14 & 10 & 262,7 & 217,6 & 21,8 \\
\hline MÉDIA* & & & $392 \pm 183$ & $40 \pm 18$ \\
\hline CV(\%) & & & 46,7 & 45 \\
\hline & & & & \\
\hline
\end{tabular}

Os resultados de média, desvio padrão e coeficiente de variação foram feitos sem os valores encontrados para os alvos 5 e 10 .

Os resultados mostram uma diferença entre a atividade experimental de ${ }^{67} \mathrm{Ga}$ e a teórica e a flutuação dos valores experimentais para uma mesma carga integrada. Esta diferença de valores entre o teórico e o experimental se explica pelo fato dos valores teóricos serem calculados a partir de curvas de função de excitação de reação nuclear, sujeitos a erros experimentais. Outro fator é a imprecisão da energia incidente no alvo devido ao espalhamento da energia do feixe no degradador utilizado. 


\subsection{Resultados da Difusão Térmica em Placas Irradiadas}

A Tabela 22 apresenta os resultados obtidos com a difusão térmica e extração em ácido acético de alvos irradiados para obtenção de ${ }^{67} \mathrm{Ga}$. $\mathrm{O}$ tempo de extração em Ácido Acético foi de 1 hora em todos os experimentos.

TABELA 22 - Resultados obtidos na extração do ${ }^{67} \mathrm{Ga}$ em ácido acético

\begin{tabular}{|c|c|c|c|c|}
\hline & $\begin{array}{c}\text { Temperatura/ Tempo } \\
\text { Aquecimento }\end{array}$ & $\begin{array}{l}\text { Atividade do } \\
\text { Alvo (MBq) }\end{array}$ & $\begin{array}{c}\text { Atividade de Extração } \\
\text { em HAc (MBq) }\end{array}$ & $\begin{array}{c}\text { \%Recuperação } \\
\text { em HAc }\end{array}$ \\
\hline 1 & $100^{\circ} \mathrm{C}, 1 \mathrm{~h}$ & 236,4 & 56,2 & 24 \\
\hline 2 & $200^{\circ} \mathrm{C}, 1 \mathrm{~h}$ & 266,4 & 173,9 & 65 \\
\hline 3 & $300^{\circ} \mathrm{C}, 1 \mathrm{~h}$ & 102,5 & 65,9 & 64 \\
\hline 4 & $300^{\circ} \mathrm{C}, 2 \mathrm{~h}$ & 128,0 & 81,8 & 64 \\
\hline 5 & $300^{\circ} \mathrm{C}, 2 \mathrm{~h}$ & 344,5 & 296,4 & 86 \\
\hline 6 & $300^{\circ} \mathrm{C}, 2 \mathrm{~h}$ & 310,4 & 199,4 & 64 \\
\hline 7 & $300^{\circ} \mathrm{C}, 2 \mathrm{~h}$ & 106,2 & 63,6 & 60 \\
\hline 8 & $300^{\circ} \mathrm{C}, 2 \mathrm{~h}$ & 122,5 & 52,2 & 43 \\
\hline 9 & $300^{\circ} \mathrm{C}, 2 \mathrm{~h}$ & 321,9 & 215,3 & 67 \\
\hline 10 & $300^{\circ} \mathrm{C}, 2 \mathrm{~h}$ & 65,1 & 51,8 & 80 \\
\hline 11 & $300^{\circ} \mathrm{C}, 2 \mathrm{~h}$ & 159,8 & 70,3 & 44 \\
\hline 12 & $300^{\circ} \mathrm{C}, 2 \mathrm{~h}$ & 279,0 & 222,0 & 80 \\
\hline 13 & $300^{\circ} \mathrm{C}, 2 \mathrm{~h}$ & 107,3 & 64,0 & 60 \\
\hline 14 & $300^{\circ} \mathrm{C}, 2 \mathrm{~h}$ & 94,7 & 75,1 & 79 \\
\hline MÉDIA* & & & & $72 \pm 10$ \\
\hline$C V(\%)$ & & & & 13,9 \\
\hline
\end{tabular}

* Média, DP e CV calculados sem os valores dos alvos 8 e 11.

No item 5.3, estabeleceu-se como condições de obtenção do ${ }^{67} \mathrm{Ga}$ aquecimento a $100{ }^{\circ} \mathrm{C}$ por 1 hora e extração em HAc por mais uma hora. 
Nestas condições, um primeiro experimento apresentou baixo rendimento, $\mathbf{2 4 \%}$. Em um segundo experimento, o alvo foi aquecido por 1 hora a $200^{\circ} \mathrm{C}$ e permaneceu em ácido acético concentrado 1 hora. Obteve-se 65\% de extração.

Para verificar se um aumento da temperatura para $300{ }^{\circ} \mathrm{C}$ e do tempo de aquecimento aumentaria a extração, em um terceiro experimento, avaliou-se o aquecimento do alvo a $300{ }^{\circ} \mathrm{C}$ por 1 hora e em um quarto experimento avaliou-se aquecimento do alvo a $300{ }^{\circ} \mathrm{C}$ por 2 horas. $\mathrm{O}$ tempo de extração em ácido acético foi mantido em 1 hora. Nestas condições o rendimento de ${ }^{67} \mathrm{Ga}$ obtido foi de $64 \%$.

Desta maneira não foram observadas diferenças significativas para as temperaturas de $200{ }^{\circ} \mathrm{C}$ e $300^{\circ} \mathrm{C}$.

Optou-se pelas seguintes condições:

(1) Aquecimento do alvo por 2 horas a $300{ }^{\circ} \mathrm{Ce}$

(2) Difusão em ácido concentrado por 1 hora.

Os dados experimentais de LUNDQVIST e colab. ${ }^{(102)}$ e LION ${ }^{(103)}$ mostraram rendimento de $56-60 \%$ e de $80 \%$ de extração de ${ }^{111}$ In dos alvos de cádmio em ácido acético concentrado, respectivamente. Os estudos de TOLMACHEV e LUNDQVIST (104) para ${ }^{66,68} \mathrm{Ga}$ mostraram $60 \%$ de extração em $\mathrm{HCl} \mathrm{0,05} \mathrm{mol} \mathrm{L}^{-1}$.

$\mathrm{O}$ rendimento médio obtido de extração do ${ }^{67} \mathrm{Ga}$ dos alvos avaliados em ácido acético concentrado foi de $(72 \pm 10) \%(n=9)$. Esta porcentagem de recuperação pode ser considerada adequada, uma vez que é compatível com o encontrado na literatura.

As variações ocorridas na extração são atribuídas aos diferentes alvos utilizados e sua variação de massa, resultando assim em maior ou menor difusão do ${ }^{67} \mathrm{Ga}$.

\subsection{Comportamento de $\mathrm{Cu}, \mathrm{Ni}, \mathrm{Zn}$ e ${ }^{67} \mathrm{Ga}$ em Resina Aniônica Dowex 1 X8}

Os ensaios iniciais realizados nos itens 4.2.7.1 e 4.2.7.2 verificaram o comportamento de ${ }^{67} \mathrm{Ga}, \mathrm{Cu}, \mathrm{Ni}$ e $\mathrm{Zn}$ em meio de HAc na resina aniônica Dowex $1 \mathrm{X} 8$.

$\mathrm{O}$ perfil de eluição de $\mathrm{Cu}, \mathrm{Ni}$ e $\mathrm{Zn}$ foi verificado pela análise química das frações coletadas em ICP-OES e a eluição do ${ }^{67} \mathrm{Ga}$ foi verificada com medida das frações coletadas em calibrador de doses.

As soluções carga, de lavagem e eluição foram passadas pela coluna, com vazão aproximadamente igual a $1,4 \mathrm{~mL} \mathrm{~min}^{-1}$, por gravidade. 
A FIG. 25 e FIG. 26 ilustram o perfil de eluição destes íons na resina aniônica Dowex $1 \times 8$.

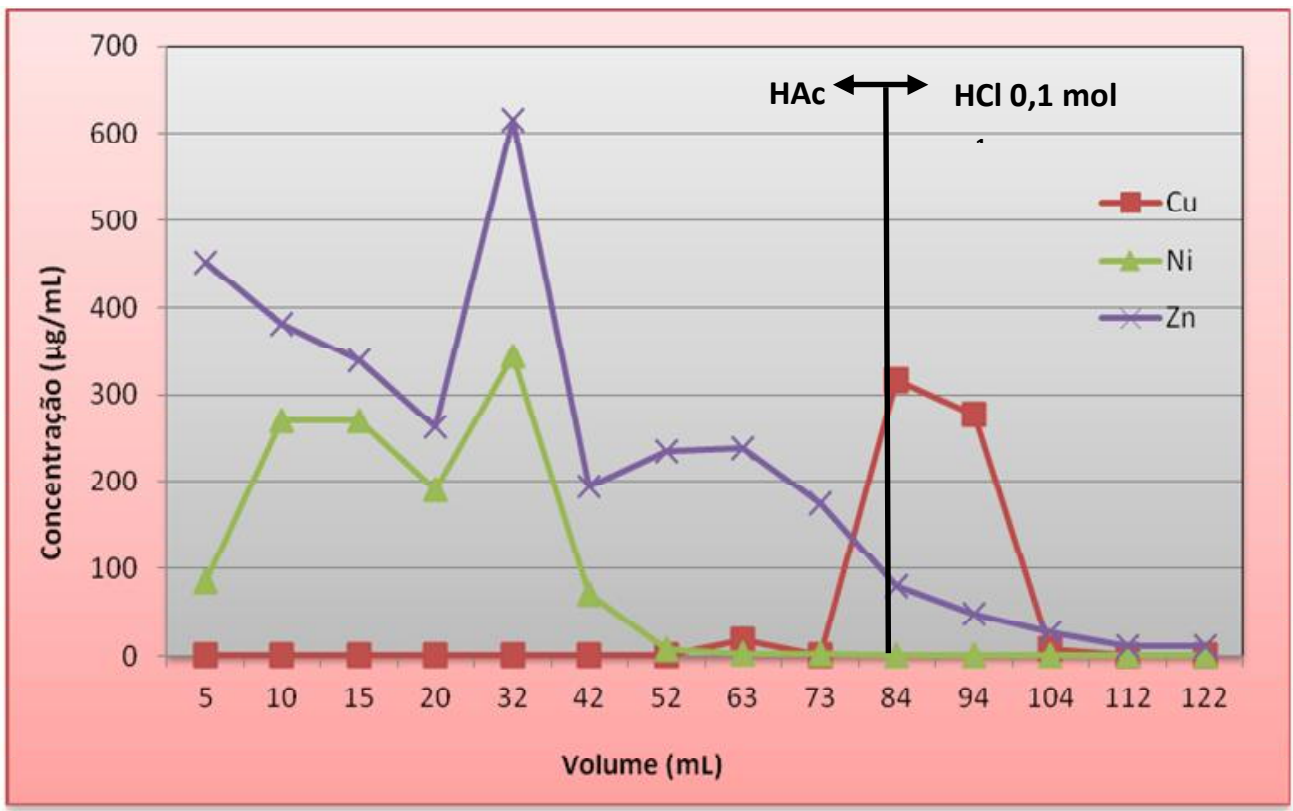

FIGURA 25 - Separação química de Zn, Ni e Cu em resina aniônica Dowex 1X8 (n= 3)

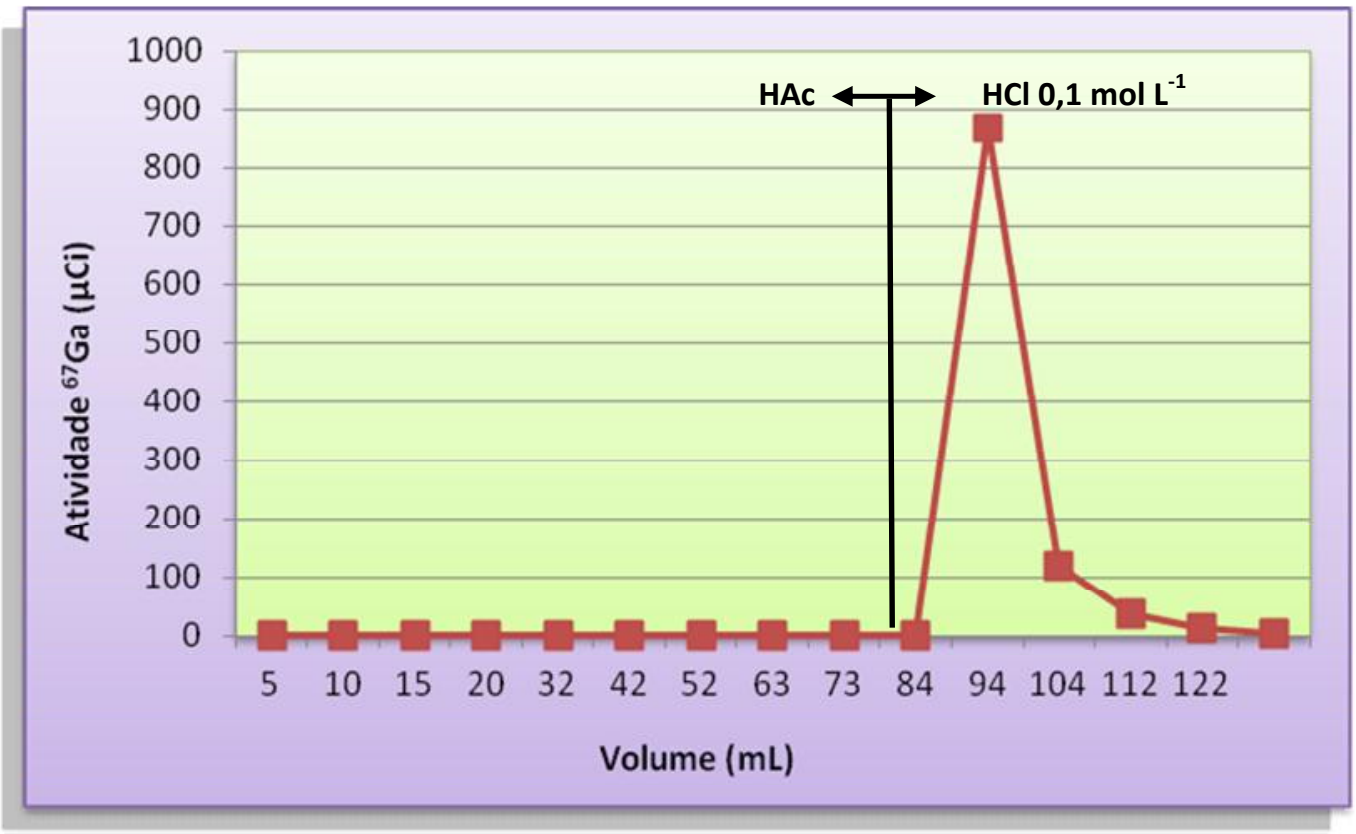

FIGURA 26 - Separação química de ${ }^{67} \mathrm{Ga}$ em resina aniônica Dowex 1 X8 $(n=3)$ 
Os elementos $\mathrm{Ni}$ e $\mathrm{Zn}$ foram eluídos em HAc com (100)\% e $(96,6 \pm 1,1) \%$ de eficiência de separação, respectivamente.

Ambos $\mathrm{Cu}$ e ${ }^{67} \mathrm{Ga}$ apresentaram o mesmo comportamento, sendo eluídos em $\mathrm{HCl}$ 0,1 $\mathrm{mol} \mathrm{L}^{-1}$ com (100 \%) de eficiência de separação. Este comportamento foi semelhante ao encontrado por Van den Winkel e col. ${ }^{(106)}$ onde Cu e Ga permanecem adsorvidos na resina em concentrações superiores a 13 e $8 \mathrm{~mol} \mathrm{~L}^{-1}$, respectivamente.

As diferenças de adsorção em relação ao $\mathrm{Ni}$ e Zn podem ser devidas às condições de separação relacionadas ao tamanho e diâmetro da coluna $(6 \times 2 \mathrm{~cm})$ que parece não ter sido eficiente na retenção destes elementos.

Apesar de não reproduzir a literatura, isto não representa limitação na utilização da resina aniônica, pois o comportamento do $\mathrm{Zn}$ e do Ga se mostraram distintos nestas condições, podendo ser separados.

Estes resultados reforçam a necessidade da camada de níquel sobre o cobre para a eletrodeposição de $\mathrm{Zn}$, pois o cobre apresenta o mesmo comportamento químico do ${ }^{67} \mathrm{Ga}$ na resina aniônica, não sendo recomendável que o zinco seja eletrodepositado diretamente sobre o cobre.

\subsection{Separação Química de ${ }^{67}$ Ga/Zn em Resina Aniônica Dowex 1 X8}

As soluções provenientes da extração em ácido acético concentrado dos alvos 1, 2 e 3 foram percoladas na resina aniônica Dowex 1X8, seguidos de $50 \mathrm{~mL}$ de HAc e $50 \mathrm{~mL}$ de $\mathrm{HCl} 0,1 \mathrm{~mol} \mathrm{~L}^{-1}$.

Todas as amostras coletadas foram medidas em calibrador de doses. ${ }^{6}{ }^{67} \mathrm{Ga}$ foi eluído em $\mathrm{HCl}$ 0,1 $\mathrm{mol} \mathrm{L}^{-1}$.

Na TAB. 23 são apresentados os resultados dos primeiros experimentos para a purificação do ${ }^{67} \mathrm{Ga}$ em resina aniônica.

TABELA 23 - Resultados obtidos na purificação do ${ }^{67}$ Ga eluído

\begin{tabular}{|c|c|c|}
\hline Experimento & Recuperação em HCl 0,1 mol L ${ }^{-1}(\%)$ & {$[\mathrm{Zn}] \mu \mathrm{g} \mathrm{mL}^{-1}$} \\
\hline 1 & 85,5 & 323 \\
\hline 2 & 87,4 & 232 \\
\hline 3 & 91,7 & 143 \\
\hline
\end{tabular}


As impurezas químicas podem ter origem do material alvo ou dos reagentes utilizados e podem interferir nas marcações das biomoléculas com radioisótopos. A $U S P^{(20)}$ e a $E P^{(9)}$ não remetem a valores para pureza química da solução final de citrato de ${ }^{67} \mathrm{Ga}$.

Para a solução de cloreto de ${ }^{111}$ In a USP recomenda que a concentração total de metais seja inferior a $1 \mu \mathrm{g} \mathrm{mL}^{-1}$. Ainda também na USP, para a solução de $\mathrm{Na}^{99 \mathrm{~m}} \mathrm{TcO}_{4}{ }^{-}$ proveniente do gerador de ${ }^{99} \mathrm{Mo} /{ }^{99 \mathrm{~m}} \mathrm{Tc}$ a concentração de alumínio deve ser inferior a 10 $\mu \mathrm{g} \mathrm{mL} \mathrm{L}^{-1}$.

De acordo com o "Manual de Especificações Técnicas dos Radiofármacos" (112) os limites de metais para a solução final de citrato de ${ }^{67} \mathrm{Ga}$ são: $\mathrm{Zn} \leq 15 \mu \mathrm{g} \mathrm{mL}{ }^{-1}$; Fe $\leq 5 \mu \mathrm{g}$ $\mathrm{mL}^{-1} ; \mathrm{Ni} \leq 3 \mu \mathrm{g} \mathrm{mL}{ }^{-1}$.

A concentração de zinco mostrou-se alta na solução final de ${ }^{67} \mathrm{Ga}$ em $\mathrm{HCl} 0,1 \mathrm{~mol}$ $\mathrm{L}^{-1}$. Isto não reproduziu os resultados encontrados no item 5.6 , para as soluções simuladas contendo ${ }^{67} \mathrm{Ga}$, Zn, Ni e $\mathrm{Cu}$, onde a maior parte do zinco saiu na lavagem com HAc. Uma possível razão seria o efeito do excesso de massa de zinco na resina aniônica nas dimensões utilizadas que ultrapassaria a capacidade da resina por $\mathrm{Zn}$.

Na solução final de ${ }^{67} \mathrm{Ga}$ as concentrações de cobre e ferro encontradas foram inferiores ao limite de detecção do método. Para o níquel, as concentrações encontradas foram inferiores a $\mathbf{2} \boldsymbol{\mu g} \mathbf{m L}^{-1}$.

Nas purificações seguintes, após a adição da carga na coluna e de $50 \mathrm{~mL}$ de HAc, percolou-se $20 \mathrm{~mL} \mathrm{HCl} 6 \mathrm{~mol} \mathrm{~L}^{-1}$ - para eluição do zinco - e finalmente, $50 \mathrm{~mL}$ de $\mathrm{HCl}$ 0,1 $\mathrm{mol} \mathrm{L}^{-1}$.

Estas amostras foram medidas em calibrador de doses e $0{ }^{67} \mathrm{Ga}$ foi eluído com $\mathrm{HCl}$ 0,1 $\mathrm{mol} \mathrm{L}^{-1}$, com eficiência de recuperação de $(92 \pm 4) \%(n=5)$. Na FIG. 27 apresenta-se a curva de eluição do ${ }^{67} \mathrm{Ga}$ na fração de $\mathrm{HCl} \mathrm{0,1} \mathrm{mol} \mathrm{L}^{-1}$. 


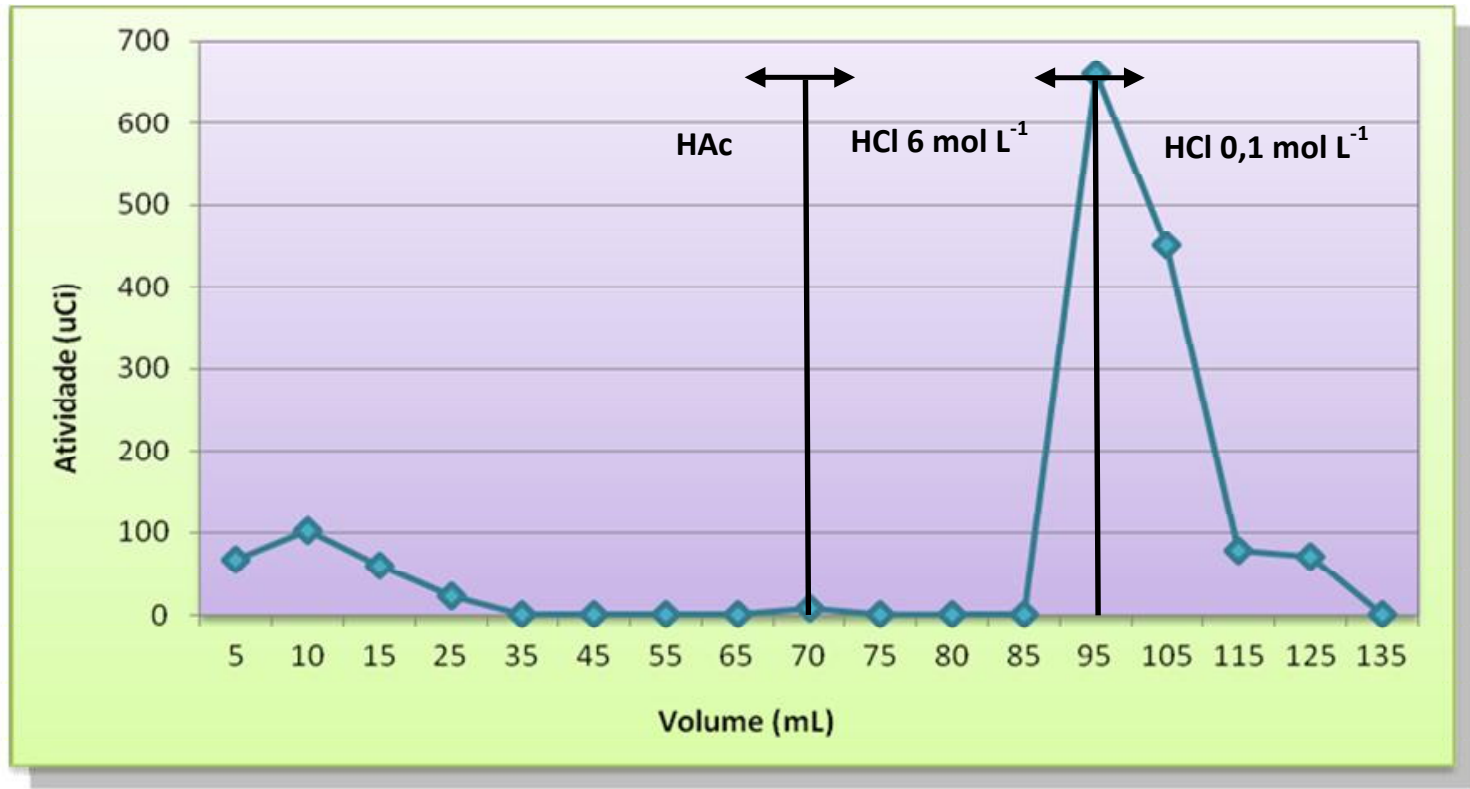

FIGURA 27 - Curva de eluição do ${ }^{67} \mathrm{Ga}^{+3}$ em resina aniônica Dowex 1 X8 ( $\left.\mathrm{n}=5\right)$

As análises químicas mostraram que não houve melhoria na diminuição de zinco no ${ }^{67} \mathrm{GaCl}_{3}$ final, com valores entre 87 e $280 \pm \mu \mathrm{g} \mathrm{mL}^{-1}$.

Como explicado no item 4.2.8, o gálio pode ser separado de níquel, cobre e zinco em resina catiônica em meio de $\mathrm{NH}_{4} \mathrm{OH}$. Os amino-complexos de cobre, níquel e zinco permanecem retidos na resina e o gálio, por apresentar caráter anfótero, é eluído da coluna na forma de hidróxido.

Os ensaios seguintes para purificação do ${ }^{67} \mathrm{Ga}$ foram realizados em resina catiônica AG 50WX8 para separação do par ${ }^{67} \mathrm{Ga} / \mathrm{Zn}$.

\subsection{Separação Química de ${ }^{67} \mathrm{Ga} / Z n$ em Resina Catiônica Dowex 50WX8}

Com resultados insatisfatórios na purificação do ${ }^{67} \mathrm{Ga}$ com resina aniônica, utilizouse a resina catiônica forte Dowex 50X8, 100-200 mesh, nas mesmas dimensões da resina aniônica, $6 \mathrm{~cm} \times 2 \mathrm{~cm}$.

Após o período de difusão e de extração em HAc das placas irradiadas, a solução contendo ${ }^{67} \mathrm{Ga}$ foi evaporada até a secura e retomada com $3 \mathrm{~mL}$ de $\mathrm{NH}_{4} \mathrm{OH} \mathrm{0,5} \mathrm{mol} \mathrm{L}^{-1}$.

Esta solução foi carregada na resina catiônica, seguidos de $30 \mathrm{~mL}$ de $\mathrm{NH}_{4} \mathrm{OH}$ 0,5 $\mathrm{mol} \mathrm{L}^{-1}$, e $10 \mathrm{~mL}$ de $\mathrm{HCl} 0,1 \mathrm{~mol} \mathrm{~L}^{-1}$. 
As soluções carga, de lavagem e eluição foram passadas pela coluna, com vazão aproximadamente igual a $1,6 \mathrm{~mL} \mathrm{~min}^{-1}$, por gravidade.

Empregando-se a resina catiônica em meio amoniacal, eluiu-se $(98 \pm 2) \%(n=5)$ do ${ }^{67} \mathrm{Ga}$ percolado na resina em $23 \mathrm{~mL}$ de $\mathrm{NH}_{4} \mathrm{OH} 0,5 \mathrm{~mol} \mathrm{~L}^{-1}$. Portanto, nas condições experimentais estudadas observou-se que o gálio na forma de íon galato $\left({ }^{67} \mathrm{Ga}(\mathrm{OH})_{4}{ }^{-}\right)$não apresentou afinidade pela resina, sendo eluído.

Na FIG. 28 é mostrada a curva de eluição do ${ }^{67} \mathrm{Ga}$ em resina catiônica, na forma alcalina.

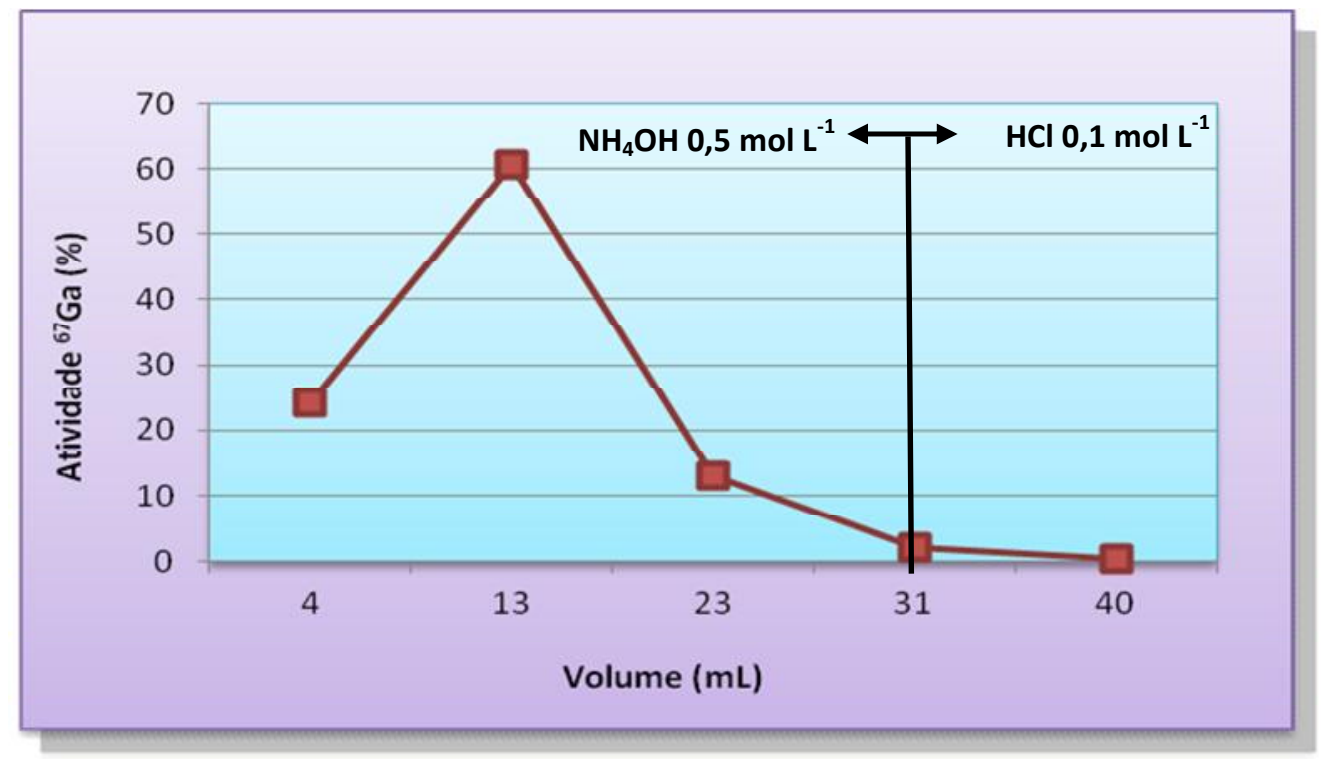

FIGURA 28 - Curva de eluição do ${ }^{67} \mathrm{Ga}$ em resina catiônica Dowex $50 \mathrm{WX8}(\mathrm{n}=5)$

A amostra da carga coletada e dos primeiros $20 \mathrm{~mL}$ lavados foram misturadas e levadas a uma nova secura. Ao resíduo adicionou-se $2 \mathrm{~mL}$ de $\mathrm{HCl} \mathrm{0,1} \mathrm{mol} \mathrm{L}^{-1}$. Não houve perda significante de material.

Esta solução foi analisada quanto ao seu conteúdo de zinco, níquel, cobre e ferro. A concentração de zinco encontrada foi de $(2 \pm 1) \mu g \mathrm{~mL}^{-1}$. Para níquel, cobre e ferro os valores encontrados foram inferiores ao limite de detecção.

Observa-se assim, que nas condições experimentais estudadas observou-se a formação de amino-complexo de zinco e dos outros metais, que apresentam afinidade pela resina, permanecendo retidos.

As análises químicas mostraram que a perda de massa de zinco na placa irradiada foi inferior a $0,02 \mathrm{~g}$. 


\subsection{Pureza Radioquímica do ${ }^{67} \mathrm{Ga}$}

A pureza radioquímica foi verificada por cromatografia em papel Whatman $3 \mathrm{MM}$ e fase móvel a mistura Piridina:Etanol:Água (1:2:4). Neste sistema cromatográfico, o Fator de Retenção (Rf) para o ${ }^{67} \mathrm{GaCl}_{3}$ é 0,0.

A forma de ${ }^{67} \mathrm{GaAc}$ foi verificada no item 4.2.7.2 na adição de HAc na amostra de ${ }^{67} \mathrm{GaCl}_{3}$ (NORDION). A Pureza Radioquímica para a forma de ${ }^{67} \mathrm{GaAc}$ foi de $\mathbf{9 7} \pm \mathbf{1 \%}(\mathrm{n}=3)$.

A forma de ${ }^{67} \mathrm{GaCl}_{3}$ foi avaliada para os eluídos obtidos da resina aniônica na primeira fração de $\mathrm{HCl} 0,1 \mathrm{~mol} \mathrm{~L}^{-1}$ que foi levada a secura, para eliminação do ácido

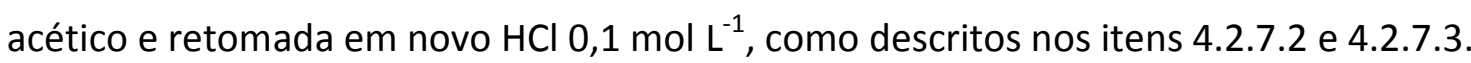

No item 4.2.8, com uso da resina catiônica, as 3 primeiras frações eluídas foram

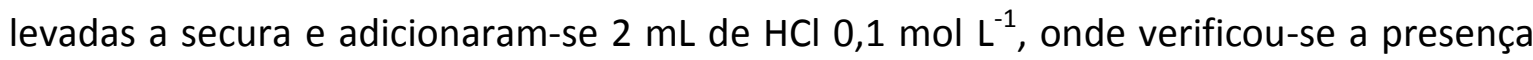
do ${ }^{67} \mathrm{GaCl}_{3}$.

Na TAB. 24 são apresentados os resultados de pureza radioquímica encontrados para a forma de ${ }^{67} \mathrm{GaCl}_{3}$.

TABELA 24. Pureza radioquímica do ${ }^{67} \mathrm{GaCl}_{3}$

\begin{tabular}{cc}
\hline AMOSTRA & $\%{ }^{67} \mathrm{GaCl}_{3}$ \\
\hline${ }^{67} \mathrm{Ga}$ Traçador/Resina Aniônica & $99 \pm 1(\mathrm{n}=3)$ \\
${ }^{67} \mathrm{Ga} /$ Resina Aniônica & $99 \pm 1(\mathrm{n}=5)$ \\
${ }^{67} \mathrm{Ga} /$ Resina Catiônica & $97 \pm 1(\mathrm{n}=5)$ \\
\hline
\end{tabular}

Os valores encontrados demonstraram que $0{ }^{67} \mathrm{Ga}$ na forma de acetato ou de hidróxido foram convertidos para a forma final de cloreto, a forma química adequada para marcação de moléculas.

\section{10 Pureza Radionuclídica do ${ }^{67}$ Ga}

A pureza radionuclídica foi verificada por espectroscopia- $\gamma$ utilizando um detector de Germânio Hiper-Puro nas soluções oriundas da difusão térmica, antes da percolação na resina (carga) e nas frações eluídas das colunas de troca iônica contendo ${ }^{67} \mathrm{Ga}$.

Foram encontrados picos referentes somente ao ${ }^{65} \mathrm{Zn}$. 
A pureza radionuclídica encontrada nas soluções de ácido acético concentrado proveniente da difusão térmica, nas frações ácidas da resina aniônica, nas frações alcalinas da resina catiônica e nos produtos finais após os procedimentos descritos foi sempre superior a $(\mathbf{9 9 , 9} \%)$.

De acordo com a USP, a solução final de citrato de ${ }^{67}$ Ga deve apresentar pureza radionuclídica superior a $99 \%{ }^{(20)}$, sendo a pureza radionuclídica encontrada satisfatória.

\subsection{Pureza Radioquímica do Citrato de ${ }^{67}$ Ga}

A pureza radioquímica foi verificada utilizando papel Whatman 3MM e Acetato de Sódio 0,16 $\mathrm{mol} \mathrm{L}^{-1}$, conforme item 4.2.12.

A FIG. 29 apresenta o cromatograma do citrato de ${ }^{67} \mathrm{Ga}$ obtido em contador linear. A Pureza Radioquímica encontrada foi de $(98 \pm 1) \%(n=5)$. Não se observaram diferenças significativas nos resultados encontrados entre o contador linear e o contador gama.

De acordo com a USP, a solução final de citrato de ${ }^{67} \mathrm{Ga}$ deve apresentar pureza radioquímica superior a $97 \%{ }^{(20)}$, sendo a pureza radioquímica encontrada satisfatória.

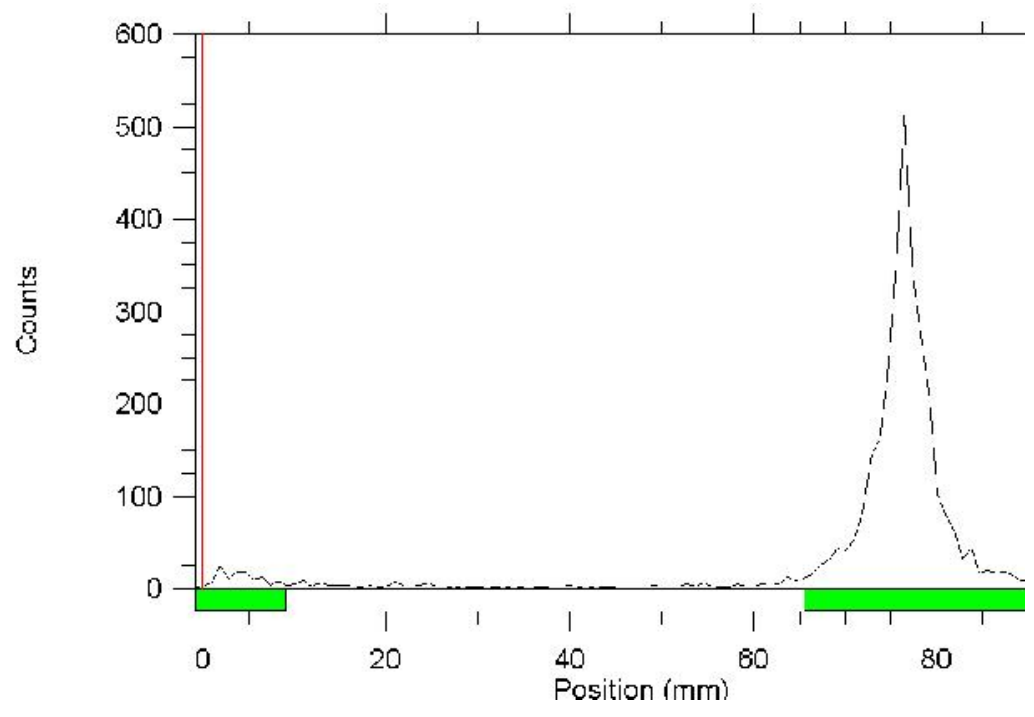

FIGURA 29 - Cromatograma do citrato de ${ }^{67} \mathrm{Ga}(n=5)$ 


\section{12 Fluxograma do Método Proposto}

A FIG. 30 representa de modo esquemático a obtenção do ${ }^{67} \mathrm{Ga}$ a partir do método proposto neste trabalho.

O tempo total do processamento ficou entre 4-5 horas.

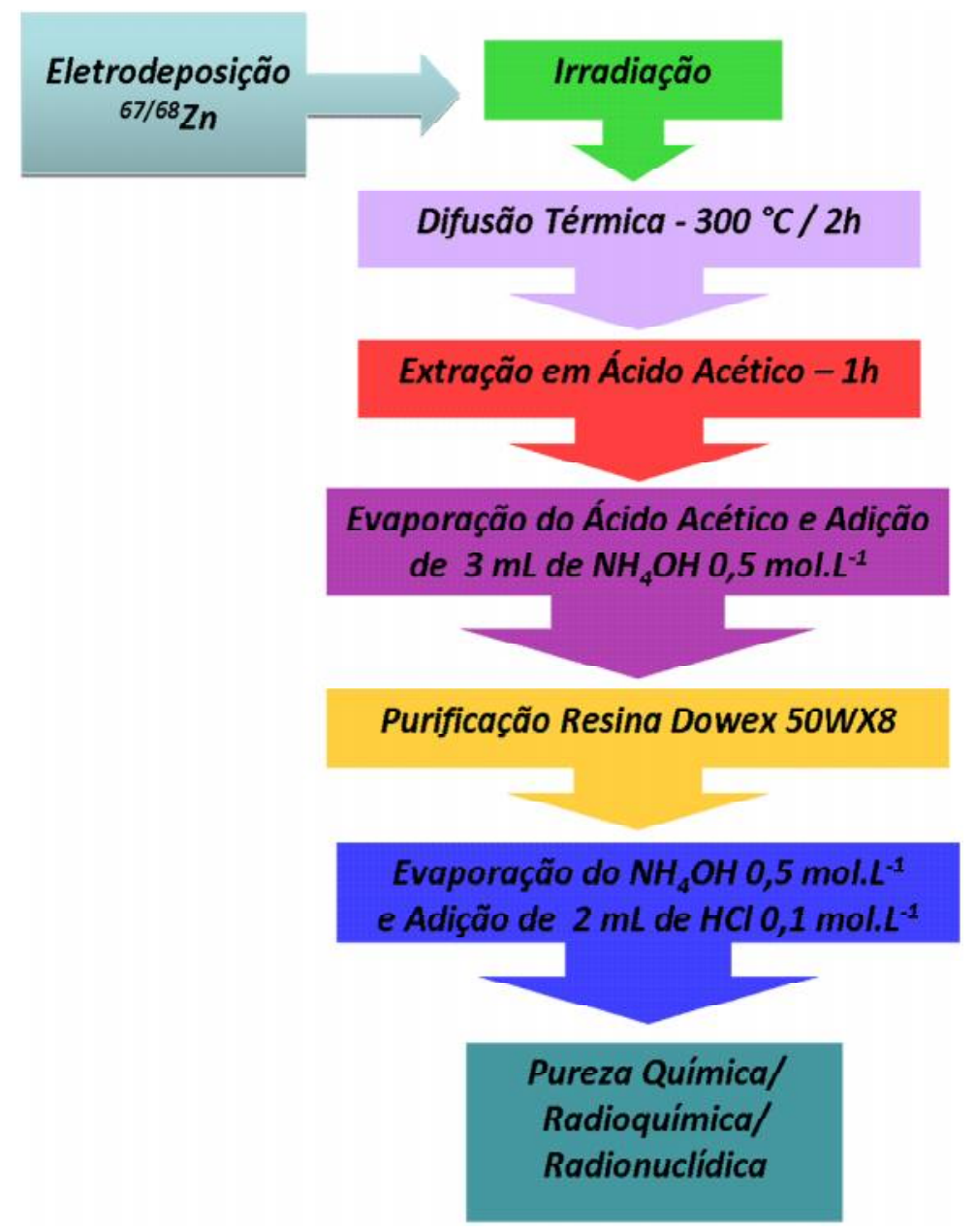

FIGURA 30. Obtenção de ${ }^{67}$ Ga por difusão térmica e extração em ácido acético 


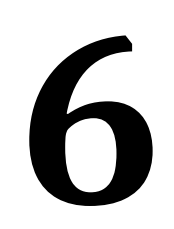

\section{CONCLUSÕES}

Desenvolveu-se um método de preparação de alvos para irradiação de zinco natural ( ${ }^{\text {nat }} \mathrm{Zn}$ ) por eletrodeposição. Os depósitos obtidos apresentaram aspecto brilhante, aderentes ao substrato de cobre niquelado e uniformes em toda superfície do subtrato. $\mathrm{O}$ processo tem duração de 2 horas e obteve-se $(0,49 \pm 0,04) g$ de massa.

Considerando-se ainda os experimentos de preparação para alvos de ${ }^{\text {nat }} \mathrm{Zn}$ ficou evidente a necessidade da camada de níquel sobre a placa de cobre devido a dois fatores:

(1) Em ácido acético concentrado ocorre uma maior dissolução do cobre;

(2) O comportamento químico do cobre é similar ao do gálio na resina aniônica Dowex $1 \times 8$.

Estas ocorrências podem levar a contaminação do ${ }^{67} \mathrm{Ga}$ com cobre, o que pode ser evitado ao se utilizar o substrato de cobre revestido com uma camada de níquel.

Como conclusão dos estudos de difusão térmica e extração em HAc para separação do ${ }^{67} \mathrm{Ga}$ do material alvo, as condições mais apropriadas foram:

(1) Difusão térmica a $300{ }^{\circ} \mathrm{C}$ por 2 horas;

(2) Extração em HAc por 1 hora.

Nestas condições $(\mathbf{7 2} \pm \mathbf{1 0}) \%$ de ${ }^{67}$ Ga foi recuperado.

A resina catiônica Dowex 50WX8, nas dimensões $6 \times 2 \mathrm{~cm}$, condicionada em meio $\mathrm{NH}_{4}{ }^{+}$mostrou-se eficiente para separação química do par ${ }^{67} \mathrm{Ga} / \mathrm{Zn}$. A recuperação do ${ }^{67} \mathrm{Ga}$ foi de (98 \pm 2) \% em $23 \mathrm{~mL}$, na forma do íon galato, ${ }^{67} \mathrm{Ga}(\mathrm{OH})_{4}$. 
A solução final de ${ }^{67} \mathrm{GaCl}_{3}$ apresentou excelente pureza química apresentando (2 \pm 1) $\mu g \mathbf{m L}^{-1}$ de zinco.

Como conclusão geral do trabalho, foi possível a separação e purificação do ${ }^{67} \mathrm{Ga}$ do material alvo a partir da difusão térmica , a extração em HAc e a purificação em resina catiônica Dowex 50WX8 em meio de $\mathrm{NH}_{4} \mathrm{OH} \mathrm{0,5}$ mol. $\mathrm{L}^{-1}$, possibilitando o processamento em um ambiente de produção menos corrosivo.

$\mathrm{O}^{67} \mathrm{GaCl}_{3}$ obtido como produto final apresentou características de pureza química e radionuclídica dentro dos limites estabelecidos internacionalmente para uso na preparação de moléculas marcadas para o radiodiagnóstico em Medicina Nuclear.

O método proposto também possibilita a reutilização direta do alvo por não ser um método destrutivo, desde que sejam observados cuidados adequados de manipulação no processo. 


\section{REFERÊNCIAS BIBLIOGRÁFICAS}

1. ROBILOTTA, C. C. A tomografia por emissão de pósitrons: uma nova modalidade na medicina nuclear brasileira. Rev Panam Salud Publica, v. 20, p. 134-142, 2006.

2. SAHA, G. B. Fundamentals of Nuclear Pharmacy; New York: Springer-Verlag, 1998.

3. TER-POGOSSIAN, M.M.; WAGNER Jr., H.N. A new look at the cyclotron for making short-lived isotopes. Nucleonics, v.24/10, p.50-56,62, 1966.

4. QAIM, S. M. Target Development for Medical Radioisotope Production a Cyclotron. Nuclear Instruments and Methods in Physics Research, A282, p. 289-295, 1989.

5. SILVA, L. J. V. Produção e Caracterização de Filmes Finos de ZnO. 2010. Dissertação (Mestrado) - Universidade Federal de Santa Maria, Rio Grande do Sul.

6. SKOOG, WEXT, HOLLER, CROUCH. Fundamentos de Química Analítica; Thomson.

7. PONTE, H. A. Fundamentos da Eletrodeposição. 2008. Disciplina Eletroquímica Aplicada à Corrosão. Universidade Federal do Paraná, Paraná.

8. IAEA. Cyclotron Produced Radionuclides: Principles and Practice. Technical Reports Series $N^{\circ} 465$, Vienna, Austria, 2008.

9. European Pharmacopeia 5.0, National Formulary 5.0. (2005).

10. ARAÚJO, E. B.; LAVINAS, T.; COLTURATO, M. T., MENGATTI, J. Garantia da qualidade aplicada à produção de radiofármacos. Brazilian J of Pharmaceutical Sciences, v. 44, p. 1-12, 2008.

11. THRALL, J. H.; ZIESSMAN, H. A. Medicina Nuclear, Rio de Janeiro: Guanabara Koogan, 2003.

12. WAGNeR, H.N.; SZABO, Z.; BUCHANAN, J.W. Principles of Nuclear Medicine, Pensilvânia: Saunders, 1995. 
13. Centro de Radiofarmácia > Quem Somos. Disponível em: http://www.ipen.br/sitio/?idm=113. Acessado em 24 jun. 2012.

14. AGÊNCIA NACIONAL DE VIGILÂNCIA SANITÁRIA (ANVISA). Regulamento Técnico das Boas Práticas para a Fabricação de Medicamentos. Brasília, 2003. (Resolução RDC 210, Diário Oficial da União, 04 ago. 2003).

15. AGÊNCIA NACIONAL DE VIGILÂNCIA SANITÁRIA (ANVISA). Boas Práticas para a Fabricação de Radiofármacos. Brasília, 2009. (Resolução RDC 63, Diário Oficial da União, 23 dez. 2009).

16. Centro de Aceleradores Cíclotron > Quem Somos > Histórico. Disponível em: http://www.ipen.br/sitio/?idc=153. Acessado em 24 jun. 2012.

17. NORDION. Disponível em: http://www.nordion.com/documents/products/Ga67_Can.pdf. Acessado em 24 jun. 2012.

18. Certificado de Análise ISORAD. Documento interno IPEN.

19. IT-CR-P03.12.07 - ${ }^{67} \mathrm{Ga}$ - Citrato de Gálio: Preparo de Alvo para Irradiação. Documento Interno IPEN.

20. U. S. Pharmacopeia 35, National Formulary 35, (2012).

21. BANDOLI, G.; DOLMELLA, A.; TISATO, F.; PORCHIA, M.; REFOSCO, F. Mononuclear sixcoordinated $\mathrm{Ga}$ (III) complexes: A comprehensive survey. Coordination Chemistry Reviews, v. 253, p. 56-77, 2009.

22. THAKUR, M. L. Gallium-67 and Indium-111 Radiopharmaceuticals. Int J Appl Radiat Isotopes, v. 28, p. 183-201, 1977.

23. MELNIKOV, P.; MALZAC, A.; COELHO, M. B. Gálio e a Patologia Óssea. Acta Ortop Bras, v. 16, p. 54-57, 2008.

24. TSAN, M. F. Mechanism of Gallium-67 Accumulation in Inflammatory Lesions. J Nucl Med, v. 26, p. 88-92, 1985.

25. TSAN, M. F.; SCHEFFEL, U. Mechanism of Gallium-67 Accumulation in Tumors. J Nucl Med, v. 27, p. 1215-1219, 1986.

26. HOUSTON, T. K.; PEACOCK, J. E.; APPEL, R. G.; COWAN, R. J. Gallium-67-Citrate Scanning of Renal Parenchymal Malacoplakia. J Nucl Med, v. 39, p. 1454-1457, 1998.

27. TEIXEIRA, A. B. M. J.; ETCHEBEHERE, E. C. SÁ C.; LIMA, M. C. L.; SANTOS, A. O.; PIRES, B. C.; VALENÇA, J. T.; RAMOS, C. D.; CAMARGO, E. E. Gallium-67 Imaging in a Patient 
with Paracoccidiodomycosis: A Case Report. Rev Inst Med Trop S Paulo, v. 42, p. 167170, 2000.

28. VANDENBOS, F.; ROGER, P. M.; MONDAIN-MITON, V.; DUNAIS, B.; FOUCHE, R.; KREITMANN P.; CARLES, D.; MIGNECO, O.; DELLAMONICA, P. Ventricular Patch Endocarditis by Propionibacterium acnes: Advantages of Gallium Scanning. Brit Infect Soc, p. 249-251, 2001.

29. SCHUSTER, D. M.; ALAZRAKI, N. Gallium and Other Agents in Diseases of the Lung. Sem Nucl Med, v. 32, p. 193-211, 2002.

30. LIM, K. K.; RADFORD, D. J. Amonidorane Pneumonitis Diagnosed by Galluim-67 Scintigraphy. Heart Lung, v. 11, p. 59-62, 2002.

31. BUNYAVIROCH, T.; AGGARWAL, A.; OATES, E. Optimized Scintigraphic Evaluation of Infection and Inflammation: Role of Single-Photon Emission Computed Tomography/Computed Tomography Fusion Imaging. Semin Nucl Med, v. 36, p. 295311, 2006.

32. MATSUI, Y.; SUGAWARA, Y.; TSUKADA, K.; KINHI, Y.; SHIBAHARA, J.; MAKUUCHI, M. Aspergillus thyroiditis in a Living Donor Liver Transplant Recipient. J Inf, v. 53, p. 231233, 2006.

33. CHANG, M-C.; TSAI, S-C.; LIN, W-Y. Value of Gallium-67 Scanning in Monitoring Therapeutic Effectiveness in a Patient with Relapsing Polychondritis. Kaohsiung J Med Sc., v. 24, p. 328-333, 2008.

34. YAVARI, A.; AYOUB, T.; LIVIERATOS, L.; RAMAN, V.; MCWILLIAMS, E. T. Diagnosis of Prothestic Aortic Valve Endocarditis with Gallium-67 Citrate Single-Photon Emission Computed Tomography/Computed Tomography Hybrid Imaging using Software Registration. Circ Cardiovasc Imaging, v. 2, p. 41-43, 2009.

35. JALILIAN, A. R.; NOVINROOZ, A.; MOTAMEDI-SEDEH, F.; MORADKHANI, S.; RAJAMAND, A. A.; SOLATI, J. Evaluation of $\left[{ }^{67} \mathrm{Ga}\right]$ Citrate in the Detection of Various Microorganism Infections in Animal Models. Iran J Nucl Med, v. 17, p. 34-41, 2009.

36. HUNG, M. Y.; HUNG, M. J.; CHENG, C. W. Use of Gallium-67 Scintigraphy to Differentiate Acute Myocarditis from Acute Myocardial Infarction. Tex Heart Int J, v. 34, p. 305-309, 2007. 
37. HIRAMASTU, S.; TADA, H.; NAITO, S.; OSHIMA, S.; TANIGUCHI, K. Steroid treatment deteriorated ventricular tachycardia in a patient with right ventricle-dominant cardiac sarcoidosis. Int J Cardiol, doi:10.1016/j.ijcard.2007.08.029, 2007.

38. Gallium Citrate Ga-67. Disponível em: http://www.drugs.com/pro/gallium-citrate-ga67.html. Acessado em 24 jun. 2012.

39. WEINER, R. E., The Mechanism of ${ }^{67} \mathrm{Ga}$ Localization in Malignant Disease. Nucl Med Biol, v. 23, p. 745-751, 1996

40. BEN-HAIM, S.; BAR-SHALOM, R.; ISRAEL, O.; HAIM, N.; EPELBAUM, R.; BEN-SHACHAR, M.; GAITINI, D.; KOLODNY, G. M.; FRONT, D. Utility of gallium-67 scintigraphy in lowgrade non-Hodgkin's lymphoma. J Clin Oncol, v. 14, p. 1936-1942, 1996.

41. LEE, K. S.; KIM, J. S.; HA, C. S.; KIM, E. E. Correlation of Gallium-67 SPECT and CT Findings in Primary Gynecologic Lymphoma. Clinical Imaging, V. 23, p. 119-124, 1999.

42. KAO, C-H. Gallium-67 Citrate Accumulation in Sinonasal Regions. Sem Nucl Med, v. 30, p. 74-75, 2000.

43. SUN, S. S.; TSAI, S. C.; SHIAU, Y. C.; LEE, J. K.; KAO, C. H. Unilateral Gallium-67 Citrate Uptake in Mucosa Associated Lymphoid Tissue Lymphoma of the Parotid Gland. Sem Nucl Med, v. 31, p. 168-169, 2001.

44. WIRTH, A.; SEYMOUR, J. F.; HICKS, R. J.; WARE, R.; FISCHER, R.; PRINCE, M.; MACMANUS, M. P.; RYAN, G.; JANUSZEWICZ, H.; WOLF, M. Fluorine-18 Fluorodeoxyglucose Positron Emission Tomography, Gallium-67 Scintigraphy and Conventional Staging for Hodgkin's Disease and Non-Hodgkin's Lymphoma. Am J Med, v. 112, p. 262-268, 2002.

45. ONIZAWA, K.; YOSHIDA, H. Evaluation of ${ }^{67} \mathrm{Ga}$ Citrate and ${ }^{99 \mathrm{~m}} \mathrm{Tc}$ Bone Scintigraphy at Initial Examination for Primary Oral Squamous Cell Carcinoma. J Oral Maxillofac Surg, v. 61, p. 913-917, 2003.

46. LI, N.; ZHU, W.; ZUO, S.; JIA, M.; SUN, J. Value of gallium-67 in differentiation of malignant tumors from benign tumors or inflammatory disease in the oral and maxilofacial. Oral Surg Oral Med Oral Pathol Oral Radiol Endod, v. 96, p. 361-367, 2003.

47. MANUEL, J. F.; CABRERA, M. E.; MARTÍ, V. C.; GIRALT, A. F.; RODRIGUEZ-REVUELTO, A. A.; FRUCTUOSO, M. A. H.; GASSET, I. C. Estudios SPECT-TAC com ${ }^{67} \mathrm{Ga}$ de La 
enfermedad linfomatosa. Su aportación em La estadificación y seguimiento de La enfermedad. Rev Esp Med Nucl, v. 25, p. 242-249, 2006.

48. RE, A.; FERRARI, S.; FRATA, P.; PIZZOCARO, C.; CRIPPA, C.; TUCCI, A.; FACCHETTI, F.; GRAZIOLI, L.; MAGRINI, S. M.; ROSSI, G. Late computed tomography scan response improvement and gallium scintigraphy evaluation as on treatment prognostic parameters to tailor treatment intensity in patients with Hodgkin's lymphoma. A prospective phase II study. Ann Onc, v. 19, p. 951-957, 2008.

49. ARROYO, E.; NAVARRO, P.; CUEVA, L.; ANANOS, M. V.; LIEVANO, P.; BARINGO, D. A. T. Gammagrafia con 67-Galio en Linfoma Primario de Mama. Rev Esp Med Nucl, v. 28, p. 32-33. 2009.

50. SANTOS, M. A.; GRAZINA, R.; NETO, A. Q.; CANTINHO, G.; GANO, L.; PATRICIO, L. Synthesis, chelating properties towards gallium and biological evaluation of two Nsubstituted 3-hydroxy-4-pyridinones. J Inorg Bio, v. 78, p. 303-311, 2000.

51. CHAVES, S.; MENDONÇA, A. C.; MARQUES, S. M.; PRATA, M. I.; SANTOS, A. C.; MARTINS, A. F.; GERALDES, C. F. G. C.; SANTOS, M. A. A gallium complex with a new tripodal tris-hydroxypyridinone for potential nuclear diagnostic imaging: solution and in vivo studies of ${ }^{67}$ Ga-labeled species. J Inorg Bio, v. 105, p. 31-38, 2011.

52. JALILIAN, A. R.; YOUSEFNIA, H.; GAROUSI, J.; NOVINROUZ, A.; RAJAMAND, A. A., SHAFAEE, K. The Development of Radiogallium-Acetylacetonate Bis(thiosemicarbazone) Complex for Tumor Imaging. Nucl Med Rev, v. 12, p. 65-71, 2009.

53. JALILIAN, A. R.; MEHDIPOUR, P.; AKHLAGHI, M.; YOUSEFNIA, H.; SHAFAll, K.

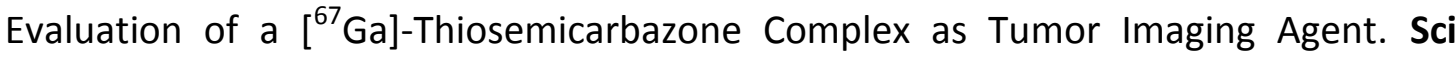
Pharm, v. 77, p. 343-354, 2009.

54. JALILIAN, A. R.; KHOSHDEL, M. R., GAROUSI, J.; YOUSEFNIA, H.; HOSSEINI, M. A., RAJABIFAR, S.; SARDARI, D. Development of a Radiolabeled $\beta$-Human Chorionic Gonadotropin. Acta Pharm, v. 59, p. 421-429, 2009.

55. COLLERY, P.; KEPPLER, B.; MADOULET, C.; DESOIZE, B. Gallium in Cancer Treatment. Crit Rev Onco/Hemat, v. 42, p. 283-296, 2002.

56. CHUA, M-S.; BERNSTEIN, L. R.; LI, R.; SO, S. K. S. Gallium Maltolate is a Promising Chemotherapeutic Agent for the Treatment of Hepatocellular Carcinoma. AntiCanc Res, v. 26, p. 1739-1744, 2006. 
57. CHITAMBAT, C. R.; PURPI, D. P.; WOODLIFF, J.; YANG, M.; WERELEY, J. P. Development of Gallium Compounds for Treatment of Lymphoma: Gallium Maltolate, a Novel Hydroxypyrone Gallium Compound, Induces Apoptosis and Circumvents Lymphoma Cell Resistance to Gallium Nitrate. J Pharma Exp Therap, v. 322, p. 12281236, 2007.

58. MULLER, C.; VLAHOV, I. R.; SANTHAPURAM, H. K. R.; LEAMON, C. P.; SCHIBLI, R. Tumor Targeting using ${ }^{67} \mathrm{Ga}$-DOTA-Bz-folate - investigation of methods to improve the tissue distribution of radiofolates. Nucl Med and Biol, v. 38, p. 715-723, 2011.

59. UDAYACHANDER, M.; MEENAKSHI, A.; MUTHIAH, R.; SIVANANDHAM, M. Tumor Targeting Potential of Lipossomes Encapsulating Ga-67 and Antobody to Dalton's Lymphoma Associated Antigen (Anti-DLAA). Int J Radiation Oncology Biol Phys, v. 13, p. 1713-1719, 1987.

60. CHENG, K-Y.; TSAI, S-C, LIN, W-Y. Gallium-67 activated charcoal: a new method for preparation of radioactive capsules for colonic study. Eur J Nucl Med Mol Imaging, v. 30, p. 907-911, 2003.

61. OGAWA, K.; TAKAI, K.; KANBARA, H.; KIWADA, T.; KITAMURA, Y.; SHIBA, K.; ODANI, A. Preparation and evaluation of a radiogallium complex-conjugated bisphophonate as a bone scintigraphy agent. Nucl Med and Biol, v. 38, p. 631-636, 2011.

62. ALDEGHERI, E. B. Avaliação in vivo e in vitro do DOTA-LANREOTIDEO Radiomarcado com Gálio-67. 2005. Tese (Doutorado) - Instituto de Pesquisas Energéticas e Nucleares - Universidade de São Paulo, São Paulo.

63. ZHERNOSEKOV, K.P. Radiochemical Aspects of Production and Processing of Radiometals for Preparation of Metalloradiopharmaceuticals. 2006. Tese (Doutorado) - Johannes Gutenberg Universität, Mainz, Alemanha.

64. JALILAN, A. R.; MIRSADEGUI, L.; HAJI-HOSSEINI, R.; KHORRAMI, A. Preparation, Quality Control and Biodistribution Studies of ${ }^{67} \mathrm{Ga}$ - DOTA-anti-CD20. Radiochim. Acta., v. 96, p. 167-174, 2008.

65. SANTOS, J. S. Avaliação da Radiomarcação da ANEXINA A5 com Tecnécio-99m: Influência do Método de Marcação nas Propriedades Físico-Químicas e Biológicas do Composto. 2009. Tese (Doutorado) - Instituto de Pesquisas Energéticas e Nucleares - Universidade de São Paulo, São Paulo.

66. LIDE, D. R.; Handbook of Chemistry and Physics. CRC Press, 1998. 
67. MAGALHÃES, M. E. A. Obtenção de gálio a partir de Rejeitos Industriais. 1990. Dissertação (Mestrado) - Instituto de Química - Universidade Estadual de Campinas, São Paulo.

68. SANTOS, C. A. LINO. Contribuições ao Processo de Eletrodeposição do Gálio sobre Cobre e Estudo das Interfases $\mathrm{Cu} / \mathrm{NaOH}$ e Pt/NaOH na Ausência e Presença de Íons Acrilato. 2003. Tese (Doutorado) - Instituto de Química - Universidade de São Paulo, São Paulo.

69. BERNSTEIN, L. R. Mechanisms of Therapeutic Activity for Gallium. Pharmacological Reviews, v. 50, p. 665-682, 1998.

70. Web Elements: The Periodic Table on the Web. Disponível em: http://www.webelements/gallium/. Acessado em 24 jun. 2012.

71. Yields of the Isotopes of the Element: Gallium - CERN. Disponível em: https://oraweb.cern.ch/pls/isolde/yield?v_url=query_tgt\&v_z=31. Acessado em 24 jun. 2012.

72. HELUS, F.; MAIER-BORST, W. A Comparative Investigation of Methods Used to Produce ${ }^{67} \mathrm{Ga}$ with a Cyclotron. Mar. 26-30, 1973, Copenhagen. Proceedings... Vienna: IAEA, 1973. (IAEA-SM-171/21).

73. Cyclotron Produced Radionuclides: Physical Characteristics and Production Methods. Technical Reports Series 468. Vienna: IAEA, 2009.

74. YUAN, M-C.; CHEN, I-J.; WANG, C-F. Primary Standardization of ${ }^{67} \mathrm{Ga}$ Radiopharmaceuticals. Appl Radiat Isotopes, v. 66, p. 976-980, 2008.

75. VLATKOVIC, M.; PAIC, G.; KAUCIC, S.; VEKIC, B. Production of ${ }^{67} \mathrm{Ga}$ by Deuteron Irradiation of Zinc. Int J Appl Radiat Isotopes, v. 26, p. 377-379, 1975.

76. NAGAME, Y.; UNNO, M.; NAKAHARA, H.; MURAKAMI, Y. Production of ${ }^{67} \mathrm{Ga}$ by Alpha Bombardeament of Natural Zinc. Int J Appl Radiat Isotopes, v. 29, p. 615-619, 1978.

77. NAIDOO, C.; VAN DER WALT, T. N. Cyclotron Production of ${ }^{67} \mathrm{Ga}$ (III) with a tandem ${ }^{\text {nat }} \mathrm{Ge}-{ }^{\text {nat }} \mathrm{Zn}$ target. Appl Radiat Isotopes, v. 54, p. 915-919, 2001.

78. NAYAK, D.; LAHIRI, S. Alternative Methods for the Production of Carrier-free ${ }^{66,67} \mathrm{Ga}$. Appl Radiat Isotopes, v. 54, p. 189-193, 2001.

79. Charged particle cross-section database for medical radioisotope production: diagnostic radioisotopes and monitor reactions. May, 2001, Vienna. Proceedings... Vienna: IAEA, 2001. (IAEA-TECDOC-1211). 
80. BONARDI, M. L.; GROPPI, F.; BIRATTARI, L. G.; MAINARDI, C.; GHIONI, A.; MENAPACE, E.; ABBAS, K.; HOLZWARTH, U.; STROOSNIJDER, M. F. Thin-target Excitation Function and Optimization of Simultaneous Production of NCA Copper-64 and Gallium-66, 67 by Deuteron Induced Nuclear Reactions on a Natural Zinc Target. J Radioanl Nucl Chem, v. 257, p. 229-231, 2003.

81. SZELECSÉNYI, F.; STEYN, G. F.; KOVACS, Z.; VAN DER WALT, T. N.; SUZUKI, K.; OKADA, K.; MUKAI, K. New Cross-Section Data for the ${ }^{66} \mathrm{Zn}(\mathrm{p}, \mathrm{n}){ }^{66} \mathrm{Ga},{ }^{68} \mathrm{Zn}(\mathrm{p}, 3 n)^{66} \mathrm{Ga}$, ${ }^{n a t} \mathrm{Zn}(\mathrm{p}, \mathrm{x}){ }^{66} \mathrm{Ga},{ }^{68} \mathrm{Zn}(\mathrm{p}, 2 \mathrm{n}){ }^{67} \mathrm{Ga},{ }^{\text {nat }} \mathrm{Zn}(\mathrm{p}, \mathrm{x}){ }^{67} \mathrm{Ga}$ Nuclear Reactions up to $100 \mathrm{MeV}$. Nucl Instrum And Meth in Phys Res, v. B234, p. 375-386, 2005.

82. ADAM-REBELES, R.; VAN DER WINKEL, P.; DE VIS, L. Optimization of Production Yields, Radionuclidic Purity and Hotcell Shielding of SPECT and PET Radionuclides Produced by Proton Irradiation in Variable Energy $20 \mathrm{MeV}$ Cyclotrons - Part ${ }^{67} \mathrm{Ga}$. Appl Radiat Isotopes, v. 65, p. 995-1013, 2007.

83. HUPF, H. B.; BEAVER, J. E. Cyclotron Production of Carrier-Free Gallium-67. Int J Appl Radiat Isotopes, v. 21, p. 75-79, 1970.

84. BROWN, L. C. Chemical Processing of Cyclotron Produced ${ }^{67} \mathrm{Ga}$. Int J Appl Radiat Isotopes, v. 22, p. 710-713, 1971.

85. DAHL, J. R.; TILBURY, R. S. The Use of a Compact, Multi-Particle Cyclotron fot the Production of ${ }^{52} \mathrm{Fe},{ }^{67} \mathrm{Ga},{ }^{111}$ In and ${ }^{123}$ I for Medical Purposes. Int J Appl Radiat Isotopes, v. 23, p. 431-437, 1972.

86. BROWN, L. C.; CALLAHAN, A. P.; SKIDMORE, M. R.; WILSON, T. B. High-Yield Zinc-68 Cyclotron Targets for Carrier-Free Gallium-67 Production. Int J Appl Radiat Isotopes, v. 24, p. 651-655, 1973.

87. COLLINS, C. H.; BRAGA, G. L.; BONATO, P. S. Introdução a métodos cromatográficos.UNICAMP:São Paulo, 1995.

88. ZINI, J. Usos das cromatografias de extração e de troca iônica na separação de tório e terras raras de um resíduo gerado na unidade de purificação de tório. Aplicação das terras raras como catalisadores na geração de hidrogênio. 2010. Tese (Doutorado) - Instituto de Pesquisas Energéticas e Nucleares - Universidade de São Paulo, São Paulo. 
89. CHAMMA, D. F. S. Produção de ${ }^{67}$ Ga para Diagnóstico em Medicina Nuclear. Rio de Janeiro, 1981. Dissertação (Mestrado) - Instituto de Engenharia Nuclear, Universidade Federal do Rio de Janeiro, Rio de Janeiro.

90. WEINREICH, R.; CHAMA, F. S. D.; FERNANDES, L.; BRAGHIROLLI, M. S. A. Extration chromatography in isotope production: aplication in th production of ${ }^{67} \mathrm{Ga}$ and ${ }^{201} \mathrm{Tl}$. J Labelled Compd Radiopharm, v. 19, p. 1423-1425, 1982.

91. ARZUMANOV, A.; BATISCHEV, V.; BORISSENKO, A.; BERDINOVA, N.; CHUMIKOV, G.; LUKASHENKO, S.; LYSSUKHIN, S.; SYCHIKOV, G. Development of Cyclotron Based High Beam Current Technique for Ga-67 Production. Proceedings of EPAC 2000, Vienna: IAEA, 2000.

92. KOPECKY, P.; MUDROVÁ, B. Chemical Processing of Cyclotron Produced Gallium-67 on Alumina Columns. Int J Appl Radiat Isotopes, v. 26, p. 323-326, 1975.

93. BRITS, R. J. N.; STRELOW, W. E. ${ }^{67} \mathrm{Ga} / \mathrm{Zn}$ Separation with an Organic Adsorvent. Appl Rad Isotopes, v. 41, p. 575-578, 1990.

94. SANTOS, E. E. Estudo da Separação de Ga e Zn por Meio de Resinas Trocadoras e de Adsorção de Íons. Obtenção de ${ }^{67}$ Ga para Uso em Medicina Nuclear. São Paulo, 1995. Dissertação (Mestrado) - Instituto de Pesquisas Energéticas e Nucleares Universidade de São Paulo, São Paulo.

95. NAYAK, D.; BANERJEE, A.; LAHIRI, S. Separation of No-carrier-added ${ }^{66,67}$ Ga Produced in Heavy Ion-induced Cobalt Target Using Alginate Biopolymers. Appl Radiat Isotopes, v. 65, p. 891-896, 2007.

96. GRUVERMAN, I. J.; KRUGER, P. Cyclotron-Produced Carrier-Free Radioisotopes. Inter J Appl Rad Isotopes., v. 5, p. 21-31, 1959.

97. SILVESTER, D. J.; THAKUR, M. L. Cyclotron Production of Carrier-Free Gallium-67. Int J Appl Radiat Isotopes, v. 21, p. 630-631, 1970.

98. CHATTOPADHYAY, S.; DAS, M. K.; SARKAR, B. R.; RAMAMOORTHY, N. Simple Procedure for the Preparation of Iron-free ${ }^{67} \mathrm{Ga}$ from na Irradiated Copper Target use of Ascorbic Acid. Appl Radiat Isotopes, v. 48, p. 211-212, 1997.

99. EL-AZONY, K. M.; FERIEG, K. H.; SALEH, Z. A. Direct separation of ${ }^{67}$ Ga citrate from zinc and copper target materials by anion exchange. Appl Radiat Isotopes, v. 59, p. 329-331, 2003. 
100. HASSAN, K. F.; Rapid Separation of Radiogallium from $\mathrm{Zn}$ and $\mathrm{Cu}$ Targets Using Anion Exchange Technique. J Radioanal Nucl Chem, DOI 10.1007/s10967-011-11454, 2011.

101. TOLMACHEV, V.; LUNDQVIST, H.; EINARSSON, L. Diffusion-based Separation Methods: Dry Distillation of Zinc, Cadmium and Mercury Isotopes from Irradiated Targets. Appl Radiat Isotopes, v. 48, p. 565-569, 1997.

102. LUNDQVIST, H.; TOLMACHEV, V.; BRUSKIN, A.; EINARSSON, L.; MALMBORG, P. Rapid Separation of ${ }^{110}$ In from Enriched Cd Targets by Thermal Diffusion. Appl Radiat Isotopes, v. 46, p. 859-863, 1995.

103. LION, F. L. Desenvolvimento de Novo Método de Produção de ${ }^{111}$ In a partir da Irradiação de Cd com Prótons. 2002. Dissertação (Mestrado) - Instituto de Pesquisas Energéticas e Nucleares - Universidade de São Paulo, São Paulo.

104. TOLMACHEV, V.; LUNDQVIST, H. Rapid Separation of Gallium from Zinc Targets by Thermal Diffusion. Appl Radiat Isotopes, v. 47, p. 297-299, 1996.

105. RUSSEL, J. B. Química Geral; São Paulo: Mc-Gray Hill do Brasil, 1982.

106. VAN DEN WINKEL, P.; CORTE, F.; HOSTE, J. Anion Exchange in Acetic Acid Solutions. Anal Chim Acta, v. 56, p. 241-259, 1971.

107. ABRÃO, A. Operações de troca iônica. São Paulo, Instituto de Energia Atômica, 1972. (Apostila da Disciplina QFL-754).

108. KULPRATHIPANJA, S.; HNATOWICH, D. J.; A Method for Determining the pH Stability Range of Gallium Radiopharmaceuticals. Inter J Appl Rad Isotopes, v. 28, p. 229-233, 1977.

109. REUS, U.; WESTMEIER, W. Catalog of Gamma Rays from Radioactive Decay, Atomic Data and Nuclear Data Tables, v. 29, 1983.

110. MAgALHÃES, M. N.; LIMA, A. C. P. Noções de Probabilidade e Estatística; São Paulo: Edusp, 2009.

111. SZELECSENYI, F.; BOOTHE, T. E.; tAVANO, E.; PlitNikAS, M. E.; TARKANYI, F. Compilation of Cross Sections/Thick Target Yields for ${ }^{66} \mathrm{Ga},{ }^{67} \mathrm{Ga}$ and ${ }^{68} \mathrm{Ga}$ Production Using Zn Targets up to $30 \mathrm{MeV}$ Proton Energy. Appl Rad Isotopes, v. 45, p. 473-500, 1994.

112. IPEN-CNEN/SP, Manual de Especificações Técnicas dos Radiofármacos, São Paulo, (2009). 